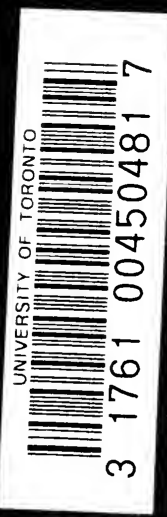

(6) 


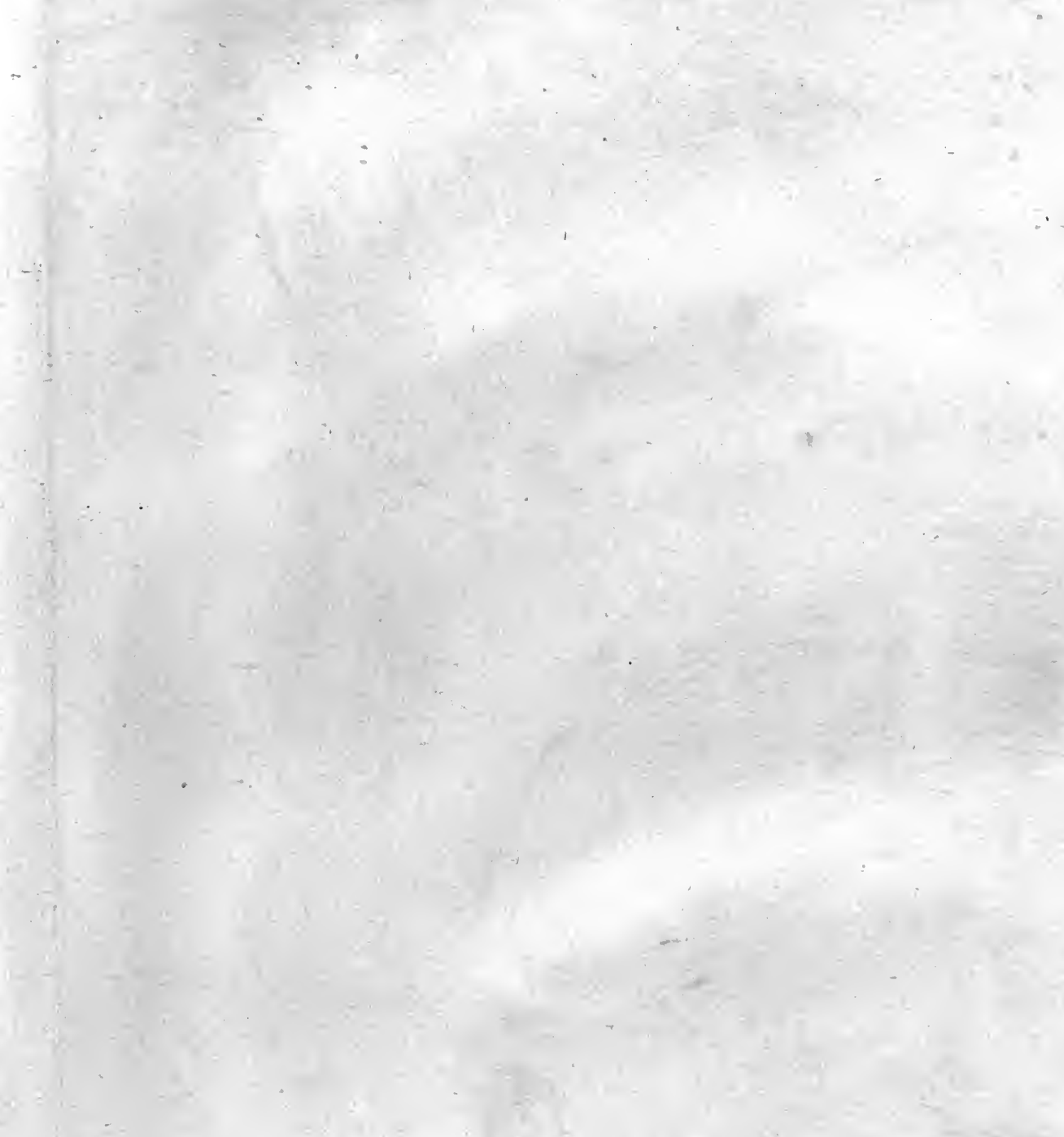
$+$

E 
50 . 4. $1 \frac{4}{4}$

$+\frac{1}{4}+\frac{1}{4}$

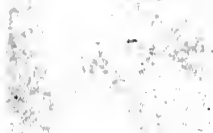

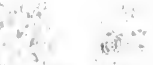

A $\cos ^{2}$

is

a. $x^{2}+y^{2}$

हैं

is

3. $n=$

है,

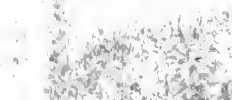

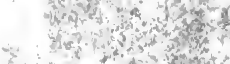
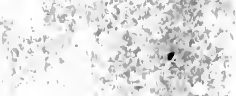

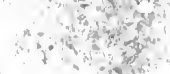

$\therefore$.

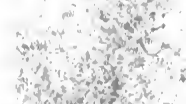

intwe
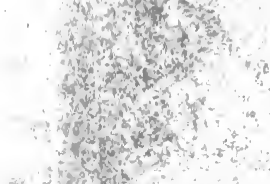

तit

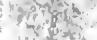

and
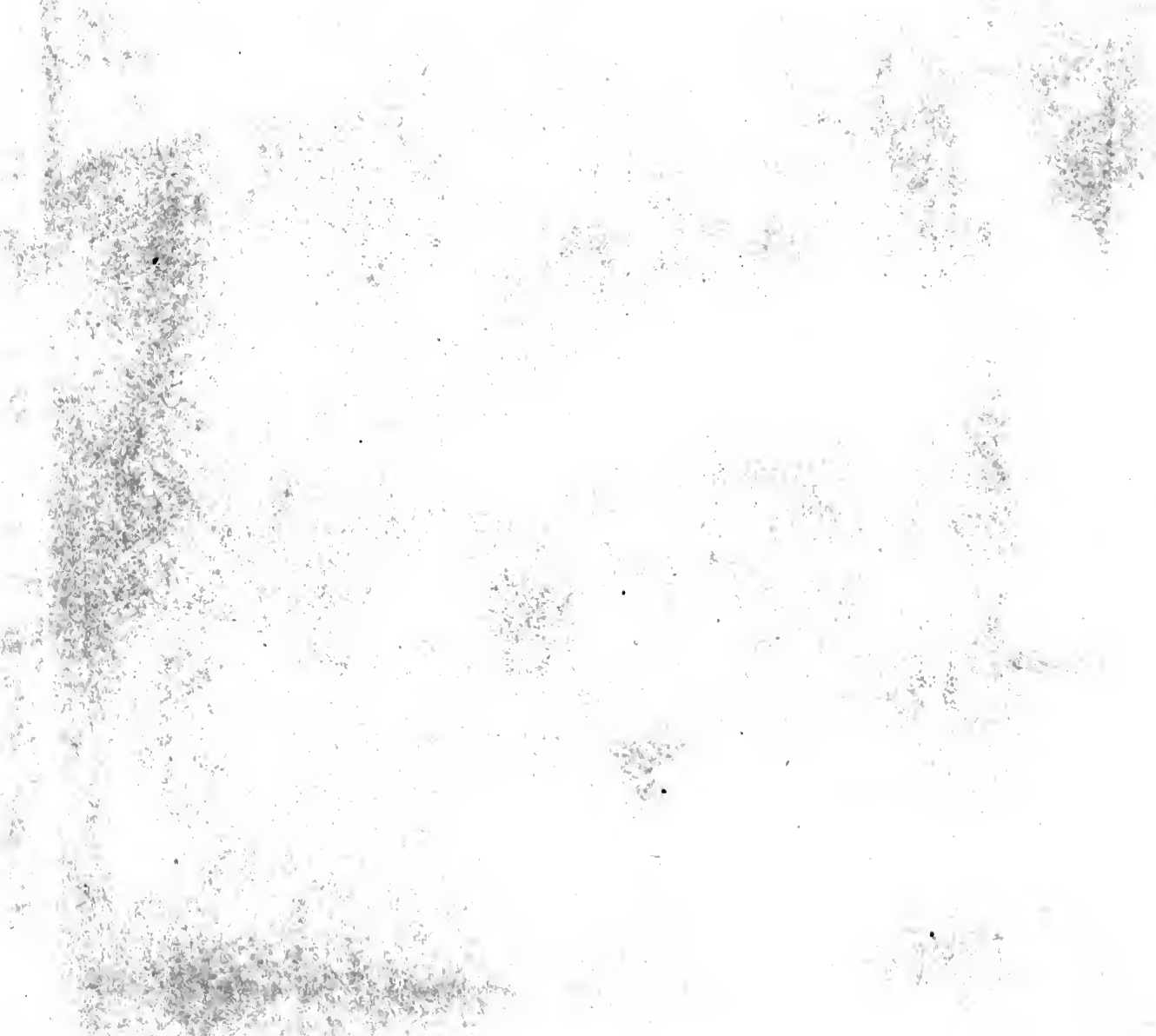
eamden Society, is s-

\title{
THE MAIRE OF BRISTOWE IS KALENDAR;
}

\author{
BY \\ ROBERT RICART,
}

TOWN CLERK OF BRISTOL 18 EDWARD IV.

EDITED BY

LUCY TOULMIN SMITH.

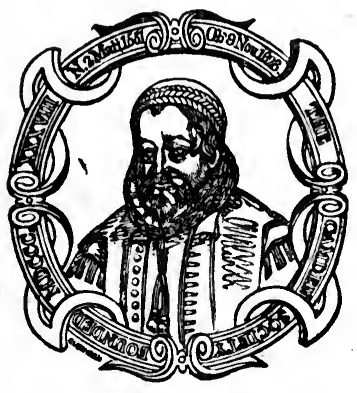

PRINTED FOR THE CAMDEN SOCIETY.

M.DCCC.LXXII. 
WESTMINSTER :

PRINTED BY J. B. NICHOLS AND SONS, 25, PARLIAMENT STREET.

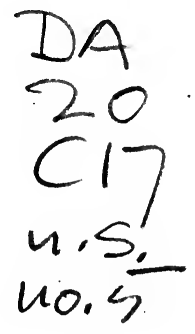

[NEW SERIES V.] 


\section{COUNCIL OF THE CAMDEN SOCIETY}

FOR THE YEAR 1872-73.

\section{President,}

SIR WILLIAM TITE, C.B., M.P., F.R.S., V.P.S.A.

THE RIGHT HON. LORD ACTON.

WILLIAM CHAPPELL, ESQ. F.S.A., Treasurer.

WILLIAM DURRANT COOPER, ESQ. F.S.A.

F. W. COSENS; ESQ.

J. WALTER K. EYTON, ESQ. F.S.A. JOHN FORSTER, ESQ. D.C.L.

JAMES GAIRDNER, ESQ.

SAMUEL RAWSON GARDINER, ESQ., Director.

ALFRED KINGSTON, ESQ.

SIR JOHN MACLEAN, F.S.A.

FREDERIC OUVRY, ESQ. Treas. S.A.

EDWARD RIMBAULT, LL.D.

EVELYN PHILIP SHIRLEY, ESQ. M.A. F.S.A.

WILLIAM JOHN THOMS, ESQ. F.S.A., Secretary.

SIR THOMAS E. WINNINGTON, BART. 
The Council of the Camden Societr desire it to be understood that they are not answerable for any opinions or observations that may appear in the Society's publications; the Editors of the several Works being alone responsible for the same. 


\section{N TRODUCTION.}

THE Corporation of Bristol possess in their Archives several valuable manuscript volumes. Among them one of the most prized is The Mayor's Register or Mayor's Kalendar, an evidence of the worthy design of a Town Clerk, 400 years ago, to collect together for the benefit of his fellow citizens some account of the history of their town, their privileges and liberties, their local and social customs, and of the municipal laws of London which they made their exemplar.

The work was compiled by Robert Ricart, as he himself tells us in his Introduction, at the instance of the Mayor, William Spencer, in whose time he was elected Town Clerk, 18 Edw. IV. A.D. 1479. Some doubt hangs over the accounts of him: we have no record of his birth or of his death, nor does it seem certain whether or not he belonged to any fraternity. The chief incidents of his life are, that he probably was a brother of the Gild of Kalendars, that he seems to have filled some official capacity towards the church of All Saints (perhaps Vestry Clerk), and to have kept the Parish Book there for twelve years, and that he was then chosen Town Clerk, the duties of which office he exercised for at least twenty-seven years. It has been stated by several authors, and especially by the Rev. Henry Rogers, who was Vicar of All Saints' Church, and had CAMD. soc. 
therefore means of access to all the then existing records and books belonging to that church, that Ricart was a lay brother of the fraternity of the Kalendars, an ancient gild attached to the Church of All Saints.* Barrett says that "he was of this fraternity and seems to have been one of the chaplains" or chantry priests ; $\dagger$ John Evans repeats the same assertion. $f$ Seyer, who is the most painstaking and most learned of all the Bristol historians (though unfortunately he did not live to complete his work), does not mention any other fact with regard to his life, than that he was Town Clerk, though he acknowledges the value of his " Register," and describes it. $\S$ Most of these writers have copied one another, without giving their originals, Barrett and Rogers excepted. Barrett gives no reference or authorities as to Ricart, besides the Mayor's Kalendar.

Rogers quotes several manuscripts, but, in accordance with the rambling style of his.book, in which his imagination has had also a large share, he gives no references, nor states where the MSS: were found. The most important of these to the present purpose are Ricart's Will and the "General Mynde" of the Parish of All Saints. Ricart is said to have left by his W'ill "a sum of money to be annually paid, in equal proportions, to the Church [of all Saints] and the Fraternity." $\|$ If this were so, in the "General Mynde," or roll of brethren and benefactors to be periodically prayed for and remembered, we should have expected to find Ricart's name mentioned according to the ordinary practice of the times. Two other MSS. are referred to by Rogers, the Parish

- Rogers Calendars of Al-Hallowen, Brystowe, 1846, p. 166. Other writers following the same story are Dallaway, Antiquities of Bristow, p. 36 note, Corry and Evans, Hist. of Bristol, 1816, ii. p. 285, Pryce, Popular Hist. of Bristol, 1861, p. 619.

+ Hist. of Bristol, 1789, p. 456.

¥ Chronological Outline, 1824, pp. 114, 127.

$\S$ Memoirs, I. Pref. pp. xi. xii.

\| Rogers, p.166. 
Minute Book (of All Saints) temp. Henry VI. and Edward IV., and an inventory of "Evidences" of the church. After some difficulty, through the good offices of Mr. Nicholls of the City Library, Bristol, the interesting volume called the Parish Minute Book has been found in the Vestry of All Saints' Church, where it still remains. The "General Mynde" " is found to be included among other things in this volume; I have not had the opportunity of examining it myself, but Mr. Nicholls assures me that no mention of Ricart or his Will appears throughout the book. The inventory of Evidences, also in the Vestry of All Saints, is a modern schedule with Abstracts of the title-deeds of ancient properties belonging to or connected with the church; it includes many belonging to the Gild of Kalendars, but there is none among them relating to any property left by Ricart. With regard to the Will, which would probably settle several points, Rogers has given no clue as to where he found it; the corporation of Bristol had the ancient right of keeping a Registry of Wills, and I have searched their "Great Book of Wills" and other volumes, but unfortunately without success; no such Will is there recorded. We have therefore no means of ascertaining the exact date of his death; all that we can be sure of is that his hand continues in the "Mayor's Kalendar" till 1506, and that it is found in the "Little Red Book" in 1508 , so that he was probably Town Clerk till that time. $\dagger$

" Quoted by Mr. Lucas (Secularia, p. 109), under the name of an "inventory."

† I am indebted to Mr. A. Heales of Doctors' Commons for making a search in the Registry of the Prerogative Court of Canterbury. But the only result was a Will, proved on 26 March, 1504, of one Robert Riccarde of Bristol, a Whittawyer, who was a parishioner of St. James. The closeness of name and date are singular ; it may be noted however that Ricart always spelled his name without variation, with one $c$ and a $t$. (See his signature on p. xxiv ) The name in different forms was not uncommon. Reginald Ricard was Steward of Bristol in 1267, Arthur Rycarte was Sheriff in 1558, while the name Rickards is known in Bristol to this day. 
Pryce gives a list of Town Clerks, * copied apparently from a list written only a few years ago on one of the first paper fly-leaves of the "Mayor's Kalendar," the original of which is now forgotten. This list gives

\section{" 1479 Robert Ricart \\ 1503 Thomas Hardings \\ 1521 John Collys."}

But, as we have seen, Robert Ricart must have been in office till 1506, probably till 1508. And by an enrollment made on fol. 218 of the "Little Red Book" "per Philippum Ricart communem clericum villæ prædictæ" on the 25 February, 10 Hen. VIII., and signed by himself, we learn that the town clerk in 1518 was Philip Ricart, not Thomas Hardings, as this list would imply. Probably further searches might reconcile these discrepancies.

Mr. Nicholls is of opinion, from a comparison of the MSS., that Robert Ricart wrote the early part of the Parish Minute Book mentioned above, from the 6th to the 18th Edward IV., in which latter year he became Town Clerk. Leland when he was in Bristol must have got hold of the Mayor's Kalendar of Robert Ricart, for he quotes several passages, and among them that as to the Trench (after p. 28) which identifies the book; he heads them with these words: "A remembraunce of memorable Acts done in Brightstow, out of a little boke of the Antiquities of the House of Calendaries in Brightstow." It might well be that he, a stranger coming to the town and being told all about this famous Gild, should be shown the work, then fresh and new, of one of its members not many years dead, and that thus confusing names and things, he should have thought that the "Mayor's Kalendar" belonged to that Gild. This passage

* Hist. of Bristol, p. 473. 
from Leland, and the probability of Ricart's hand in the Parish Minute Book, are the only grounds for the assumption that he was a brother of the Kalendars that I have been able to discover. It is however very likely that a member of that peculiar body, which consisted of laymen as well as clergy, should have been appointed to keep the Parish book of the church to which it was attached.* Nor of course

* The Gild of Kalendars in Bristol must have been one of the oldest Gilds in England, as well as one of the most remarkable in its objects. A fire which unfortunately took place among its muniments at an early date (said to be 1466) destroyed many valuable records which would have thrown light upon its history, but owing to its connection with the Corporation enough have been preserved, together with gleanings from other sources, to enable some idea to be formed of its scope and importance. But there is no account of this Gild among the Returns sent in from Gilds in 1389 which are preserved in the Record Office.

William Worcester, writing about 1478 , says that it was founded about A.D. 700, " ut per literas certificatorias tempore Sancti Wolstani episcopi sub antiqua manu vidi et legi." (Itinerary in Dallaway, p. 144.) It was a brotherhood of the clergy and laity, men and women, of the people of Bristol, and in very early times used to meet in the church of the Holy Trinity, otherwise Christ Church, but in the time of Henry II. it was removed by the influence of Robert Earl of Gloucester and Robert Fitzharding, a burgess of Bristol, to the church of All Saints. "At this tyme" (says Leland, Itin. ed. Hearne, vol. vii. p. 88) “ were scholes ordeyned in Brightstow by them [the two Roberts] for the conversion of the Jewes, and pute in the ordre of the Calendaries and the Maior." Leland goes on to say, however, that "William, Erle of Glocester, founder of the monastery of Cainesham [see after, p. 23], gave the præfecture and mastarshipe of the schole in Brightstow to Cainesham, and tooke it from the Calendaries." This, if true, must have been after the year 1171, when the Abbey of Keynsham was founded.

In 1216 Henry III. held a Parliament at Bristol, and at this, according to the Inquisition hereafter referred to, the King and the legate Gualo approved of the gild " propter antiquitates et bonitates in eâ Gildâ repertas," and Gualo commended it to the care of William de Bleys, Bishop of Worcester, within whose diocese Bristol lay. It was in this same year that the town procured one of its principal charters (see p. 4), and it was an opportunity taken by the Gild also to get its rights and privileges confirmed or re-affirmed by high authority; we find in the "Little Red Book" (fos 82,83 ) the entry at length of the Rule or Ordinances of the brotherhood of Kalendars as approved by William de Bleys, and with his help confirmed by the Pope. These ordinances, which are in Latin, resemble those of other Gilds, making provision for regular meetings of the members on the first Monday in each month, visiting the sick, burial, prayer for the dead, mutual help, and good behaviour, new members to 
would there be any difficulty in his continuing in the Gild after he was made Town Clerk. But there does seem much difficulty in

be of "honest conversation and good report." In 1318 there seem to have been some complaints made of the infringement of their rights, and on a mandate of the then Bishop of Worcester an Inquiry was made by the chief men of the Monastery of St. Augustine's (the church of All Saints was impropriate to this Monastery), and of the Corporation of Bristol, into their history and privileges. A copy of the "Inquisition" returned thereupon to the Bishop is also in the "Little Red Book" (fo. $83 \mathrm{~b}$ ); it traces the early history of the Gild, and the establishment of the schools for the "Jews and others" (but does not mention any transfer of these to Keynsham), and recites the confirmation of their rights in 1216.

The Gild possessed much property. In 1333 we find a deed for building a house upon the wall of the north side of All Saints Church for the use and habitation of the Prior and co-brethren, and again in 1443 and 1466 other deeds referring to the rebuilding or repair of their house or houses. ("Abstract of Deeds" belonging to All Saints, referred to above, p. iii.; see also Barrett p. 450.) In 1464 (the days of William Canynges) provision was made as to a library, lately erected in the house of the Kalendars; Barrett (pp. 453, 454; see also Dallaway, p. 34 note) quotes from a highly interesting deed of that date in the Conncil Chamber, by which it is appointed that all who wish to enter for the sake of instruction shall have "free access and recess" at certain times, and that, lest the books should be lost, three inventories shall be made, to be yearly collated with the books, which books shall be chained in the room, and for the loss of which heavy penalties are imposed on the prior. The prior to be appointed by the Mayor. This library seems to have been built over a Chapel of the Virgin on the north side of All Saints, abutting at one end to the belfry of the church, and on the other end to the honse of the Kalendars; and though "the antiquities of the Calendaries were for the moste parte brent by chaunce" (Lel. Itin. vii.p. 87), yet this fire, of which mention is frequently made, does not appear to have so utterly destroyed the library but that it was built up again and continued in its original occupation until 2 Edw. VI. (1548), when the Gild was put an end to with other bodies of the same nature.

The possessions of the Gild in 1548 were considerable, and were granted by the Crown with other properties to Sir M. Partriche and his brother (Misc. Augmentation Book, vol. Ixvii. fol. 563; Let. Patent. 2 Edw. VI. Pt. vii. m. 14, both in the Public Record Office), who in a month's time granted away again the house of the late Kalendars, " and one chamber annexed to the said house called the Library." ("Abstract of Deeds" 10 Nov. 1548.)

With this glimpse of the old Library * the history of the Gild closes. Beginning as

* In the vestry-room of All Saints' Church two old MS. volnmes of theological writings in not very good preservation still exist, together with several early printed books, which are considered to be the remains of the old Library of the Kalendars. 
believing him to have been a chantry priest, the duties of the two offices being apparently incompatible. What the duties of the town clerk were may be partly gathered from his oath (see p. 75 note); and that Ricart was active in fulfilling them is evidenced by the numerous entries in his hand-writing to be found in the "Great Red Book," "the Book of Wills," and the " Little Red Book," to say nothing of the "Mayor's Kalendar." Until, therefore, the fact of his being a priest can be proved, the mere conjectures of different writers must be taken as of no value.

There is no direct evidence on the point, but it seems a probable conjecture that Ricart should have been a friend or acquaintance of William Worcester, who not long before the time that Ricart entered on his official duties had been pacing round his native town and writing down his celebrated "Itinerary." Worcester (or -Botoner, as he sometimes calls himself, after his mother's - name,) was born at a house on St. James's Back, in 1415; after long absence, in the later years of his life, he settled again in Bristol, where his father had been a glover, and his uncle, Thomas Botoner, a brother of the Kalendars; ${ }^{*}$ he seems to have made his Itinerary of

" zilda seu fraria communitatis cleri et populi Bristolliæ," bretheren and sistren (Inquisition of 1318), it was officially connected with the municipal officers (see after, p. 73), as well as with the ecclesiastical; and though without further means of information it is difficult to say what part it took in the life of the town, this cannot have been inconsiderable when the Mayor had the right of presenting the prior and even by his oath was enjoined to support the Gild, and when at successive periods its functions embraced the care of a school, and the maintaining a free library, perhaps also the keeping of the records of the town. (See English Gilds, p. 287, Barrett, 449.)

The best account of the Kalendars is in Barrett's History, pp. 449-458. The account printed in "English Gilds," p. 287, must have been written in the seventeenth century, and contains a short abstract of the Inquisition of 1318, which it states to have been taken on account of the fire. Nothing of this kind, however, appears in that document itself.

* Dallaway's Antiquities of Bristowe, 1834, pp. 17, 35, 165. This volume contains 
Bristol about 1478*. He was a bookish man, and an "industrious antiquary," fond of reading and of writing down collections of various kinds, historical and otherwise; here was Ricart also writing for posterity, and gathering what he could together, in order to refresh the memory of his fellow citizens, what more likely than that Worcester should let him have the use now and then of his commonplace book or give him the benefit of his measurements, possibly in return for other information? Whether the plan or drawing at p. 10 (as to which Ricart is silent) was made by Worcester cannot be told; it is not made according to his measurements, but there seems every probability that the leonine verses on the Kings of England (after p. 7 note, p. 11) were drawn from Worcester's stores, for they are found, as hereafter noticed, in one of his MSS. in the Heralds' College.

The volume entitled the "Mayor's Kalendar" is a thick, square folio of paper, containing 332 leaves, which has been anciently bound in leather and re-covered at some later date. In the original binding of the book before it was written upon, according to an old fashion, each quire of paper was inclosed in a leaf of parchment, so that the volume is interspersed at places with pairs of parchment leaves, advantage of which has been taken in two or three instances to use for illuminated drawings. The writing is neat and clear, $\dagger$ for the most part by Ricart himself, $\ddagger$ except of course the part of the chronicle since his time, and a few other documents which have

a short account of Worcester and his works, together with his Itinerary for Bristol at length, with notes.

* Itinerary of Will. Worcester. Nasmith's ed. 1778, Preface.

$\dagger$ There are a few contractions which have been extended in the print. The side notes where they occur, being for the most part unimportant, are omitted, except inthe French ordinances in the sixth Part, where they have been printed in italics.

¥ See a few lines at top of the Plan, p. 10. 
been inserted later. The initial letters of the First Part are illuminated in blue and red, and there are elaborate ornaments in red ink down the left side of each of the first six leaves. Many of the headings and principal words are entirely or partially rubricated. The MS. is throughout Ricart's portion written within four ruled red lines, leaving a margin varying from $1 \frac{1}{2}$ to 2 inches. The first pages are much thumbed and worn at the edges, and are getting very dirty with much turning over, but the book is otherwise in good preservation.'

Inside the cover are some paper fly-leaves containing recently written lists of some of the Officers of the Corporation. Then come two parchment leaves, apparently part of an old Court Roll with which the volume was bound in, at the beginning and end, on the second of which is written the list of books in the Town Clerk's custody in 1621 (see after, p. xxii).

The book is divided into six Parts, the first three of which are devoted to history, the last three to local customs and laws. Between the place where Ricart left off his chronicle in the third Part, and the beginning of the fourth Part, he left a space of fifteen blank leaves, not dreaming doubtless of the years to come after him in which his book would be continued to be used. But his successors, following the same plan as his, of writing the names of the chief officers of the city and devoting half a page to each year (whether filled in with events or not), soon of course came to an end of these; they then passed on to the blank leaves at the end of the fourth Part, and when these were finished to those at the end of the fifth Part, where the entries still continue. The book, therefore, until this arrangement is perceived, presents a very confused appearance, especially when in addition it is found that several other documents CAMD. SOc. 
have, later, been inserted, wherever a page could be spared for them; but, looking at it under Ricart's original plan, the "Kalendar" is methodical in design and execution, and bears a fair comparison with other compilations of a like character. A leaf near the end contains a short "Index contentorum," written about Elizabeth's time.

Several contemporary drawings occur on various pages, most of which are intended to be portraits of Kings. To take them in order: on the first folio, at the top of the page, above the words "in honorem," \&c., is the drawing a description of which is given in the note to p. 1. Barrett, referring to this, calls it a sign of Ricart's " monkish genius and turn of mind."

On fo. 5 is the curious plan or picture of Bristol, a photo-lithograph of which is given at p. 10. This is drawn in ink on a paper leaf, the roofs of the houses being roughly washed over with red or green; the ornaments of the high cross are yellow. The four streets here represented still exist in the heart of the city; the gate of St. John is still there, under the church of that name, but the walls are to be seen no longer; the fate of the high cross, called by Worcester "Crux Magnifica," and which cost 20l. in 1491 to be "peynted and gilt," is told in the following extract: "The ancient market cross was of excellent tabernacle work with niches, containing regal effigies, and was not inferior to others at Coventry, Gloucester, and Winchester, the only ones now remaining. It was erected in 1373 to the height of thirty-nine feet. It was considered as a nuisance, and sacrificed to modern convenience, in 1733; re-erected in the centre of the College Green, and again taken down in 1763. Mr. Hoare the banker, with a true spirit of antiquarian piety, begged. the fragments, which he restored at an expense of $300 l$; and it 
now [1828] ornaments the celebrated pleasure-grounds at Stour. head."*

Fo. 8. King Arthur sitting, crowned, with a sceptre, dressed in a short close-girded coat, and long-pointed shoes. Most of these pictures of the Kings are poorly drawn and coloured, but they are interesting as giving some notion of the various dress of the time at which they were drawn.

At the beginning of the second Part is a full-page picture rudely drawn of William the Conqueror on horseback, armed, his horse richly caparisoned, with many soldiers bearing pikes and cross-bows.

Fo. 29. William Rufus. He is represented in a scarlet furred gown with a white dog at his feet.

Fo. 32. Henry I., is in long robes, sitting.

On fos. 37, 40, 47, 50, respectively, are Stephen, Henry II. Richard I. and John. At fo. 59 comes Henry III. Two figures are here portrayed, the King sitting, in his ermined robes with sceptre and crown, the Cardinal in a scarlet gown standing near, having just crowned him.

Fo. 74. A good ink drawing of Edward I. Fo. 83. Edward II.

Fo. 100. "Primus Vicecomes Bristolliæ," +three figures; the centre one, being the sheriff, is sitting, dressed in a scarlet flowing gown lined with white, with a blue dome cap or hat on his head having a gold rose or ornament in front. The other two men stand one on either side, bare-headed, one bearing the axe, the other the mace, dressed in parti-coloured gowns of blue and murrey, the latter rayed with blue and yellow.

* Retrospective Review, vol. ii. Series ii. p. 458, note. Besides the High or Market cross there were others in Bristol, the Stallenge, the Gallows, and the Temple crosses. See after, pp. xviii, 51.

$\dagger$ See p. 36 . 
Fos. 101 and 113. Richard II. and Henry VI. end the early drawings of the Kings.

On fo. 152, a parchment leaf at the beginning of the fourth Part, is the picture of the induction of the Mayor, of which a photograph (reduced in size) is given opposite the title-page. This picture fills the whole page, and is a carefully-drawn and well-coloured illumination. It is a representation of the scene described at pages 70-72, a scene which has yearly taken place with more or less variation down to the passing of the Municipal Reform Act of 1835. Dark blue hangings are on the walls of the Guildhall, above which are the arms of the city emblazoned in the windows; * the old Mayor hands the Bible to the new Mayor while the Town Clerk below reads him the oath, the Sheriff and the Aldermen standing near. These six upper figures are dressed in scarlet, lined with grey fur. Next the Clerk stands the sword-bearer, with the Mayor's sword in blue scabbard worked with gold, and hat of office (see p. 74), the serjeants and other officers habited like the two last in parti-coloured robes of murrey and dark blue rayed with red (see p. 81 as to the "town ray' liveries"), stand round the the table at the top, bottom, and left hand. At the right hand are more of the Aldermen in their scarlet gowns. The table is covered with a green cloth, on which are placed a white bag of money tied with red strings, an ink-stand and penner, $\nmid$ a parchment roll, and at the extreme right the black leather case in which the Bible was kept. Outside the bar are the

* The shield to the right bears the old arms of Bristol, of which several differing delineations are given by Seyer, Mem. Brist. i. p. 380, this among the rest. In the centre are the arms of England, temp. Hen.VI., and to the left is the cross of St. George.

† In a painting of Christ and the Doctors, by Gandenzio Ferrari (A.D. 1484), in the collection of the late Sir Thomas Phillipps at Cheltenham, there is an ink-stand with pen-case attached exactly resembling that in Ricart's picture. 
commonalty looking on, their gowns are all one coloured-green, blue, scarlet, murrey, \&c.; some are with hats and some without. This illumination resembles very much in style and finish four illustrations of the superior Courts of Law of the time of Henry VI.. copies and descriptions of which were communicated by the late $\mathrm{Mr}$. G. R. Corner to the Society of Antiquaries in 1865, and published in fac-simile in the Archæologia.

It seems to have been a custom among some of our towns, which perhaps a more extended knowledge of the closed stores of old municipal Corporations will show to have been general, that a book should be written by some one connected with the Corporation, usually the Town Clerk, which, quite apart from official minutes or legal matters of record, should be devoted to collecting information as to the early history of the town (often combined with chronicles of national history), and to preserving the body of its laws, privileges, and customs. Such a book was the valuable Liber de Antiquis Legibus of London, written in 1274. Such also was the Liber Albus, John Carpenter's famous work, compiled in 1419, and Arnold's Chronicle of London, is of the same character. Ricart's Kalendar is one of this kind. Seyers remarks that "there is in Bristol a number of MS. calendars or chronicles, containing a list of the magistrates of each year, and an account of such events as happened under each. These are not peculiar to Bristol: they are found in London, Coventry, and Oxford. *** Most of those in Bristol, but not all, were written within the last 200 years; but they are evidently derived from more ancient copies, transcribed by various bands. $* * *$ Several of the older are written on narrow rolls of vellum; one of them is in the City Library: "* and he states

* Mem. Bristol, Preface, pp. x. xi. I have not been able to find any of these. 
that he had seen about twenty of them, though there were probably more. He goes on to say that "far the best" is one by William Adams, but that " the most remarkable" is the one written by Ricart. The Custumal of Sandwich presents a near parallel to Ricart's work; begun in 1301, it was copied and added to by a Town Clerk in Edward IV.'s reign and continued by his successors, and the reason for writing the book, "quia litera scripta manet, in adjutorium et consilium eorum qui villam prædictam fuerint postmodum gubernaturi," may fitly be compared with Ricart's words (pp. 3, 69).* All these necessarily were compilations, made up in great part from the official books of record to which the writer had access, and they are valuable to us now, both from the facts they actually contain, and from the view they frequently give of the stand-point in their day that the municipal government occupied.

Ricart's book is designed with some care, and it is unlike many other books found in Corporation archives in that it does not repeat itself ; in common with other chroniclers, he drew from the popular historical narratives of his day; as Town Clerk he had access to many authentic sources of information which he made free use of. $\mathrm{He}$ divides his book into " six principall matiers," prefacing the whole with a prologue in which he dedicates it and explains its origin, and devotes a few words to point out what each "Principale" is "to shew."

The first Part consists of the History of England, from Brute to the defeat of Harold, the early part taken from some version of Geoffry of Monmouth; at the end are added three other extracts on different subjects. $\uparrow$ The story of Arthur $\ddagger$ is the most favoured

* Boys' Hist. of Sandwich, Pref. p. v, p. 495. † Doscribed in the note pp. 7, 8.

¥ The relation of the beginning of the quarrel between Arthur and Lucius is 


\section{among those of the early apocryphal kings, which are for the most part told very shortly.}

different to what $I$ have seen elsewhere, and is so picturesque that it may be interesting to give it here.

[Letter from the EMperor of RoMe, AND KiNg ARTHUR's Reply.]

"The thirde day of the feste, as kinge Arthur sate at his dyner amonges these kinges and grete lordes, came to fore hym twelf aged personnes, richely vyseene in silk, and curteisly salued the Kinge, seieng they were comme from Rome, Messingers from themperoure, and deliuerd him a lettre seyeng in this wise :-

We Mervaille gretely that thowe art ones so hardy to opyn the eyen in thyn hedde to begynne stryff and werre against vs of Rome, that aught and must jugge all the worlde. But thu hast not yet previd ne assaied the strenght of the Romaynes, but thu shalt knowe and preve it in short tyme. Julius Cesar oure Auncestre conquerid alle Bretaigne, and toke thereof Truage, and oure people hane sithen contynued the same, and thu through thi pride nowe withholdest it. Wherfore we command the that thu pay it. And yet thow hast doon grettir foly, for thu hast slayne Frolle, owre good baronne and oure capitaigne of Parys, and kepist Fraunce wrongfully. Therfore all the Cominaltee of Romains somon the, and commaunde the vpon lyf and membre that thow be in hast at Rome to do right of thi folie, and make amendys of that thu hast misdone. And yef thu comme not we shalle passe the mountaignes with grete strength, and shalle seche the whereuer thow may be founde, and thu shalt not holde oon fote of grounde but we shulle haue it, and aftirwards do by thi body at oure wille.

Whan this lettre was redde alle tho of Kinge Arthurs hows were wrothe and the Bretonnes wolde have slayne the messingiers. But Arthure wolde not suffre them. He saide they were messingers and shulde have none harme, but receiued them worshipfully, and ded them grete chiere. And after dyner he counceillid with his Kynges, Erles, and Baronnes, whate aunswere was best to make vnto the messingers. And they counceilled him all by one accorde to assemble all his pouer of all his lordeshippes, and to avenge him on the Emperoure of the dispite that he ded him in sendinge that lettre. And so all they swere God and his holy names that they wolde goo with him and help him by all theire pouer, and never to faille him to dey for. And then Arthure let write a newe lettre, and sende it to themperoure by the saide messingiers, seyeng in this wise :-

KNOWE YE WELL amongist yow of Rome that I Arthur am kinge of Bretaigne, and $I$ holde Fraunce and shall holde it, and hastely shalbe at Rome, not for to paie truce but for to aske truce. For Constantyne, the sonne of Eleyn, quene of Bretaigne, was Emperoure of Rome and of all thonnoure belonginge thereto. And Maximian kinge of Bretaign conquered all Frannce and Alemaigne and past the mountaignes and conquered all Lombardy. Thees two were myn auncestres, and all that they had and hield I shall haue and holde, yef God will. 
The second Part is an abridgement from Matthew of Westminster (in part of which it seems that Ricart had the help of another scribe), with occasionally a few additions woven in.* Though abridged, the chronicle is faithfully carried on year by year from the beginning of William the Conqueror's reign: and this Part, together with the next, presents the uncommon sight of an attempt made to record in one book, either events, or officers chosen, for every year from the Norman Conquest down to the present time.

The third Part begins with the Coronation of Henry III., and the first entry of Mayor and Prepositi is made under the first year of that king's reign. This it is to be presumed is the earliest year for which Ricart could find the officers recorded, though he himself says, at the beginning of the fourth Part, that "there hath been alweyes Maires in this worshipfull toune seth the Conquest and byfore." + No other record of the officers beyond this date is known among the City archives, and Ricart's book, which contains the unbroken list down to the present day, and still continues in use in each succeeding year, is looked upon as authoritative. In the oldest book belonging to the Corporation of Bristol, the "Little

When this lettre was made and seallid, Arthur gave the messingers riche gifftes, and so they departid from the Courte home to Rome, and shewid vnto the Emperoure how nobly and how richely they founde Arthur, and whate company was with him, and how he demeanid him in his hows, more richer and rialler then any Emperoure or kyng lyveng.

* See the preliminary note on p. 17. The reader is requested to supply the omission, in its proper place on p. 23, of the passage referred to in that note as to Eleanor, John's niece, as follows : “Mccij. Joh'is iiij. * * * And the same king John send Alianora, suster of the said Arthur, vnto the Castell of Bristowe, and ther lay in prison vnto the cominge of kinge Harry, son to kinge John, and so there she deide."

+ Seyer, who was well acquainted with the City documents, and printed the Charters of Bristol, says, that, " so far as I can find, no charter for the election of a Mayor has been discovered, or quoted by any succeeding charter." Mem. Bristol, vol. ii. p. 7. 
Red Book," at fos. 8 to 10, there is a cotemporary list of Mayors, Sheriffs, and Bailiffs, from $40 \mathrm{Edw}$. III. to $4 \mathrm{Edw}$. IV. (1367 to 1465), with which Ricart's Chronicle for the same period agrees, with but one or two trivial exceptions, and an apparent difference of one year in some of the dates. This last however is to be explained, as are several other apparent discrepancies of this kind, by the endeavour of the writer to reconcile the different dates,- the year of the mayoralty which began on the 15th September, the regnal year which began differently with each king, and the year of our Lord which began on 25th March. Lists of the Mayors of Bristol have been printed before, by Barrett (History of Bristol, 1789, p. 668), and Pryce (Popular History of Bristol, 1861, pp. 474-493), the last of whom also gives the other officers. Barrett is however inaccurate in many particulars, both as to names and dates; Pryce has copied Barrett's list as far as A.D. 1478 (after which date he has followed Ricart), saying, while he acknowledges that it differs from Ricart's, that "it is perhaps as correct as any other, and the only one with which the popular reader can be at all familiar"!

Going over the record of these chief officers for a space thus exceeding 600 years, it is found that while the name of Mayor has remained constant since Henry III., the names and number of his "brethren," as Ricart calls them, have varied from time to time, as is shown by the following table:

1 Hen. III. to 50 Hen. III., Mayor and two Prepositi.

51 Hen. III. to 3 Edw. II., Mayor and two Senescalli.

4 Edw. II. to 46 Edw. III., Mayor and two Ballivi.

47 Edw. III. to 15 Hen. VII., Mayor, Vicecomes, and two Ballivi.

$16 \mathrm{Hen}$. VII. to $21 \mathrm{Hen}$. VIII., Mayor, and two Vicecomites ac Ballivi.

22 Hen. VIII. to $5 \& 6$ Will. IV., Mayor, and two Vicecomites.

$5 \& 6$ Will. IV. and at present, Mayor, and one Sheriff.

CAMD. SOC. 
Among many entries of interest made by Ricart and his successors, attention may be called to the following:*-notes as to the building [or repair] of Redcliff Church $\dagger$ (pp. 32, 36), and as to William Canynges (p. 44) ; the refusal of assistance by Bristol to the Cornish rebellion of 1497 (p. 48); the provision of the wages for the Members of Parliament (pp. 49,50) ; the disconnection of Bristol with the Court of the Marches of Wales (p. 51); the visit of George Wishart to Bristol (p. 55) ; conspiracies in the West against Elizabeth (p. 61) ; the entertainment of Anne, Queen of James I. (p. 65); help to the wounded in the fight between Van Tromp and Blake in 1652 (p. 67).

The fourth Part is one of the most curious in the book; Ricart specially wrote it for the guidance in their duties of the officers of the town, whom he most earnestly exhorts to read it. It details the manner of electing the Mayor and the customs connected therewith;

* When Ricart wrote, Edward IV. was King, who seems to have been popular in Bristol, and to have been well received there with shows and rejoicings (see p. 43). In a MS. in Lambeth Palace (vol. 306, fol. 132), is found the following fragment, illustrating this, written apparently in the early part of the sixteenth century :

"The receyvyng of kyng Edward the iijth at Brystowe. First atte the comyng ynne atte Temple Gate there stode Wylliam Conquerour with iij. lordis, and these were his wordis:-

Well come Edwarde, oure son of high degré,

Many yeeris hast bou lakkyd owte of this londe,

I am thy fore fader, Wylliam of Normandye,

To see thy welefare here thrugh goddys sond.

Over the same gate stondyng a greet Gyaunt delyueryng the keyes. The Receyuyng atte Temple Crosse next folowyng. There was seynt George on horsbakke vppon a tent fyghtyng with a dragon, and be kyng and be quene on hygh in a castell, and his doughter benethe with a lambe. And atte the sleyng of the dragon ther was a greet melody of aungellys."

$\dagger$ The authenticity of Ricart's information in these two passages has been doubted (Pryce "The Canynges Family," p. 219; Archæologia, vol. xxxv. 282). No one has noticed however that he did not write them at all. See after, p. 32 note. 
it recounts the taking of oaths* by the officers, and many matters concerning the government of the town, the regulation of bread, ale, wood and coal, the administration of justice, and keeping the peace. Here it is found, as in several other towns, that the Mayor and corporate officers took part in the popular festivals and plays as a matter of right and custom; they were ready to receive St. Katherine's players in November; and next month to give the weight of their authority to the festival of the Boy Bishop ; $\dagger$ while they were careful also to keep their Advent sermons. It may be observed that these matters are treated of in the order of the almanac, beginning on 1st September and ending with Christmas, which accounts for the fact that other popular customs known to have existed in Bristol, such as the setting of the watch on the eves of St. John and St. Peter, are not mentioned. $\ddagger$

The fifth Part does not carry out the first idea of a kalendar

* Of the oaths themselves there is a collection, probably of the date 1344 , in the "Little Red Book," similar to that in the Liber Albus, pp. 300-314. See also those entered after Ricart's time, after pp. 87-90.

+ Sharp notes the use of "the play of St. Katherine," at Coventry (Coventry Mysteries, p. 9). As to the festival of the Boy Bishop, see Hone's "Ancient Mysteries," pp. 195-199, Brand's “ Popular Antiquities," vol. i. pp. 328-336, and Dr. Rock's "Church of Our Fathers," vol. iii. part 2, p. 215.

- ‡ Bristol, like Worcester ("English Gilds," p. 408), adds another to the number of towns where the keeping of the midsummer watch was an important ceremony held by the municipal officers attended by the crafts. In the "Great Red Book," fol. $14 b$ (mis-quoted by Barrett, p. 125), it is recorded that " 20th May, 28 Hen. VI. it was ordained by William Canynges, Mayor, and the Common Council, that the drinking at St. John's and St. Peter's nights should utterly be lefte among persons of crafts, going the nights before the Mayor, Sheriff, and notable persons ; and that the Mayor and Sheriff on forfeiture of five marks apiece, the one at St. John's night, the other at St. Peter's, should dispense wine to be disposed to the said crafts at their halls : viz. to the weavers and tuckers each ten gallons, provided that the craftsmen send their own servants with their own potts for the same," enumerating twenty-six crafts who were to have ninety-four gallons of wine among them. See this subject treated fully in Sharp's Coventry Mysteries, pp. 174-206. 
of franchises and liberties (see p. 5), but is simply a transcript of the Charter of $47 \mathrm{Edw}$. III., together with a table of the contents of John's Charter.*

:The sixth Part is, Ricart tells us, "wretin oute of a boke that was maistir Henry Daarcy sometyme recorder of London in kinge Edward the thirdes daies." The constant communication between Bristol and London, and the friendly feeling between them, receive illustration from this borrowing of "grete president" for the laws touching a great variety of important subjects of internal government; but how or when this, which is evidently a transcript of the original French, and not a compilation drawn up by Ricart, was made, can only be conjectured. Henry Darcy was Mayor, not Recorder (as Ricart twice repeats, see pp. 6, 93) of London in 1337 and 1338 ; there was no Recorder of that name during the reign of Edw. III. In $18 \mathrm{Edw}$. III. (1344) the Commonalty of Bristol made a revision of their Ordinances, and caused them to be written down by W. de Colford, their Recorder, in the "Little Red Book" (fol. 13); it would seem not unlikely that at such a time they should have made use of the experience of the great City, and that, more than 100 years afterwards, Ricart going up to London should borrow one of their Books of Constitutions, in order to give his fellow citizens the benefit of the original in his own compilation. I have made a careful search among the old books of the City of London at Guildhall, aided by suggestions kindly made by Mr. H. T. Riley, for any book that might answer to the description of the one used by Ricart, but there is no book known there under the name of Henry Darcy, nor any in which I could find the whole or even many of the laws copied into the Mayor's Kalendar. A large part of them are found 
in the Liber Albus, but that was compiled in 1419, many years later than Edward III. ; Fitz Elwyn's Building Assize, but none else, is found in the Liber de Antiquis Legibus; a considerable portion which contains many points of interest* for the student of the old customs and constitution of London, is not, to the best of my belief, in either the Liber Legum, Liber Ordinationem, Liber Memorandum, or Liber Dunthorn, of London. Perhaps the book may have been one of those formerly belonging to the City and now lost, possibly the Magnus Liber de Chartis et Libertatibus Civitatis, which wás existing in 1327.† However may have been their original, these old Ordinances of London, found in a distant part of the country, are now printed for the first time.

The last entries in the volume are not inserted in the chronicle under their proper date, but are simply copies at the end of the book of the official papers upon which Bristol Castle was annexed to the City, without comment or remark.

Upon the whole, the volume may be held to be a fair specimen of a class of which but few are published. It has been made use of by some of the local writers, principally by Seyer, who printed several extracts in his work. Much of the early chronicle is of course of no value; in preparing it for the press I have therefore left out most of this, so as to begin at a date near to the chronicler's own time; nor have I thought it necessary to give the continuous list of Mayors, \&c. after 1479, because it has been printed by Pryce, as before mentioned, from this very Kalendar. The notes at the beginning of each Part will give further explanation.

As the records in the possession of the Corporation of Bristol,

* See after, pp. 95-113.

† See Mr. Riley's Preface to Liber Albus, p. xvii.. 
which were kindly placed at my disposal by the Town Clerk, and of which I have made frequent use in these pages, are generally unknown beyond the scattered references and allusions to them in the local historians, it may not be out of place here to give a few words as to the nature and contents of the chief of them. The parchment fly-leaf at the beginning of the " Mayor's Kalendar," a very appropriate place, contains the following note, written in $1621:-$

Civitas

Bristoll.
"A trew and perfect note of all bokes, registers, and old recordes as are remayneing in the charge and keppinge of the Towne Clerck at his studye in the Councell Chamber, taken the 24th day of Januarie 1621, Anno Regni Domini Regis Jacobi nunc Angliæ \&c. decimo nono, tempore maiorati Roberti Rogers: and belonginge to the Cittye.

JAMES DieR.

1. This very booke called the Register or Mr. Maior's Kalender.

2. The old Register of Wills covered with leather.

3. Item the great redd booke.

? 4. Item an old Register of Recognizances with two lockes.

5. Item a parchment booke of the Gaunts charters.

6. Item a parchment booke for recoveryes.

7. Item a new register of wills covered with vellam.

8. Item a like Register for recognizances."

Of these books, existing 250 years ago, we have the first before us. There are now in the Council House three books of Wills, one marked the Great Orphan Book and Book of. Wills, and two called Register Books of Wills. The first of these I believe is the same as No. 2 of the note of 1621 (though it is not now covered with leather but vellum); it extends from the 6 Richard II. 1382, to 1633 ; ${ }^{*}$ the greater part of its contents are Wills, but there are also a great many entries of private deeds, indentures of feoffments

* This book is described in the Retrospective Review, vol. ii. of 2nd Series, p. 471 note, as beginning with $\mathrm{W}$ Will of May 8, 1282, $10 \mathrm{Edw}$. I. The first leaf of the book is now gone, but leaf iii contains the date 6 Richard II., 1382. 
and purchases. The second and third are simply Registers of Wills from 1594 to 1633 , and from 1633 to 1674 ; the second is the No. 7 of 1621 , the third of course is new since then. Nos. 4, 6, and 8 I could not hear of', but they are probably safe in some corner, their names and contents alike unknown and undisturbed. No. 5, the Book of the Gaunts Charters, must have been the book containing the title deeds and charters of the religious house of St. Mark of Billeswick, commonly called the Gaunts, which was purchased by the Corporation at the dissolution, and in which an Orphan School was afterwards established, now the Grammar School (see p. 56). The existence of this book also, though it was used and quoted by Barrett (p. 358) so late as 1789 , does not seem to be known in the Council House. No. 3, The Great Red Book, is still in the Council House: this, together with the Little Red Book, and the Mayor's Kalendar, are three of the most valuable and interesting among the records. The Great Red Book is a large thick folio of paper in its original binding; its contents belong chiefly to the reigns of Henry VI. and Edw. IV., though some extend as far as 38 Henry VIII., and are shortly these:-details of the sums payable for each tenement or house as Langable, and rental of the Ferm of the town; Agreements, Charters and acquitances, dating from 24 Hen. I., though entered later; many Acts of Council and Ordinances of Crafts; the documents founding and establishing several Chantries; a few "Recognizances for Orphans;" the duties and privileges of the "Water-bailly." The volume yields several curious and historical notices, for instance, as to the acknowledgement of the Kings Henry VI. and Edward IV., and help given to them, by the Town; the method of "the dispendinge of the gonnepowdyr that was hadde from Harry Maye in the tyme of William Canynges, 
maire," is not without interest; while of more local import, but showing the care taken to maintain the dignity and fair fame of the Mayors, are some curious proceedings, extending over many pages, detailed in a "remembraunce nevir to be put in oblyvion but to be hadde in perpetuell memory of all the trewe burgeises and lovers of the towne of Bristowe, of the innaturell demeanyng and the inordinate behavyng of Thomas Norton of Bristowe, gentleman, against the noble, trewe, and famous marchaunt, William Spencer," Mayor in $18 \mathrm{Edw}$. IV., "gadered and compiled by John Twynyho then. Recorder of the said towne" * (fol. 297).

The Little Red Book is a smaller and more ancient volume than the last; it is of paper, at least as old as 1344, witnessed by the following heading to a body of Ordinances beginning fol. 13: "In honorem dei omnipotentis et pro tranquillitate pacis villam $B$. inhabitantium, ad rogatum communitatis ejusdem ville, ego $\mathrm{W}$. de Colford extunc ibidem recordator $18 \mathrm{Edw}$. III., ordinaciones consuetudines ac libertates subscriptas pro communitate ville predicte factas recordari feci et in presenti papiro, \&c. ascribi," \&c. On the outside of one of the covers is the following inscription, signed by Robert Ricart himself, written on a piece of parchment which is covered with a slice of horn:- "Liber rubeus ville Bristollie, in quo continentur plurime libertates franchesieque, constitucione[s] dicte ville, Ordinaciones diuersarum arcium, composicionesque pluri[m]arum canteriarum, ac aliarum multarum cartarum libertatum $\dagger$ a tempore quo non existat memoria impetratarum.

\section{RICART Ro."}

* The chief part of another similar " remembraunce" on behalf of the Mayor in $22 \mathrm{Edw}$. IV. (fol. 313) was published in the Transactions of the Archæological section of the Birmingham and Midland Institute for 1870.

+ "Libertatu" in the original. 
To this description it may be added that the book contains the Oath of the electors to the Council ; Rentals of the Town; lists of the Mayors (see before, p. xvii) and of the 48 "electors;" Redcliff Charters; the Ordinances named above; "Lex Mercatoria;" many Ordinances of Crafts; the "Roules, de Oleroun" and the "Estatutz de la Myer" (fol. 31b); a list of the towns within the jurisdiction of the Admiralty of Bristol (fol. 99); copies of Bristol Charters ; Compositions of Chantries; enrolments of the Charters of many other Towns shown on the claim of privileges, $i$. e. for "allocatio"; Oaths of Officers; an order to proclaim "The leege taken bytwixt Englond and Castyle 12 July 7 Edw. [IV.]"; Proclamations to be made in the town periodically, \&c. The last entry is dated 1574.

Besides these there are the Mayor's Audit Books, which do not go back earlier than 1532, and the Great White Book of Records, dating from 1496 to 1590 . This book, though half empty, is remarkable for the details of a great Variance between the Abbot of St. Augustine's and the Mayor and Sheriffs of the Town,* which incidentally contain much valuable information as to the old history of the town. It also contains lists of the charges and expenses of different officers; copies of charters; exemptions and liberties given to individuals; orders as to sewers, and orphans, \&c. Many of the official documents bear the signatures of J. Cæsar, Walsingham, and Burghley.

Besides these records, $\dagger$ there is no doubt that there are many

* See after, p. 56 note.

+ The materials for the History of Bristol abound, though scattered, and need but that some one should take up the pen of a Freeman, and complete what Mr. Seyer so well began. The collections made by Mr. Seyer for the second part of his work are unfortunately divided; he bequeathed his MSS. deeds and charters to the Bristol Library (not the City Library), where they are, I believe, about to be arranged and indexed: his notes and papers are in private hands. Some of the parish chests in 
others in the archives of the municipal authorities, which, when the time comes that they shall be examined and arranged so as to ensure their safety from the accidents of unknown loss or decay, may prove equally worthy of consideration. At present it is to be regretted that even these -volumes here noticed, though under most careful custody, are not all labelled or endorsed, so that it is with difficulty they are recognized by those who do not understand their contents.

I must not conclude without the pleasure of rendering my acknowledgments for the courtesies shown me by the gentlemen of the Council House of Bristol, especially by the Town Clerk and Mr. Treasurer Harford ; and for the friendly aid of Mr. J. F. Nicholls, of the City Library, Bristol. My best thanks are also due to Mr. James Gairdner, of the Public Record Office, for the kind assistance he has given me on several occasions in the preparation of this volume.

$$
\text { L. T. S. }
$$

Highgate, March, 1872.

Bristol also do now or did possess large numbers of deeds and other MSS., for instance, All Saints. Barrett mentions (Preface, p. vii.) the existence of a MS. in Corpus Christi College, Cambridge, cCCCV. p. 26, entitled Constitutiones Villa Bristollia, the date about 1314 he thinks; and, to gather in other scattered threads, the British Museum possesses, besides a charter relating to St. Michael's Mount, Bristol, of A.D. 1236 (Add. Charter 6518), several MSS., especially three volumes, the first of which (Egerton 2044) contains transcripts made in the seventeenth century of the City laws and ordinances from 1467 to 1656, and of a number of Wills; the other two (Add. MSS. 24784-5) consist of a large number of official extracts made from the Public Records and otherwise, beginning at an early date, apparently for the purposes of a Case respecting the City dues which was tried some years ago.

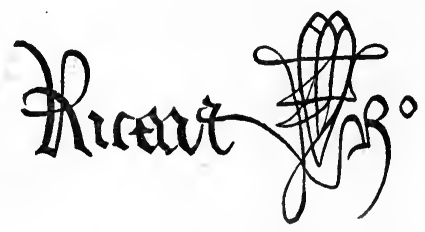




\section{CONTENTS.}

Introduction.

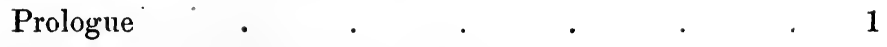

Primum Principale ‘ $\quad$. $\quad$. $\quad$. $\quad$. 6

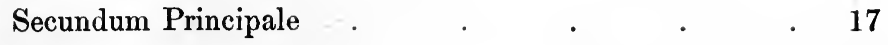

Tertium Principale $\quad . \quad$. $\quad$. $\quad$. 25

Letters Patent making Bristol a bishopric . $\quad 55$ note

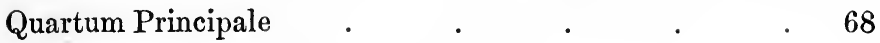

Oaths of officers, temp. Queen Elizabeth . $\quad$ - . 87

Quintum Principale . $\quad . \quad$. $\quad . \quad 50$

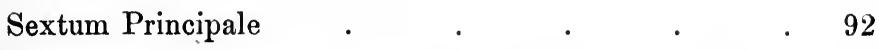

Documents as to the annexation of the Castle . . 113

Swearing-in the Mayor of Bristol . to face the title-page.

Plan of Bristol . . . t to face p. 10.

Facsimile of Robert Ricart's signature. p. xxvi. 


\section{ERRATA.}

Page xxi. of Introduction, read Liber Ordinationum, Liber Memorandorum, \&c.

On page 97 dele the word sic and the asterisk.

P. xiv. line 12 from top, writers instead of writer.

P. xvi. insert inverted commas after the word lyveng, end of first paragraph of note. 


\section{RICART'S KALENDAR.}

* In honorem dei omnipotentis gloriamque, laudem suæ benedictæ Fo. $0 b$. matris, pro tranquillitate pacis ac prosperitate villam Bristolliæ inhabitantium, necnon pro consuetudinibus, ordinationibus, liber. tatibus, et franchesiis dictæ villæ melius imposterum fore conservatis et manutentis, ad requisitum et mandatum venerabilis viri Willi. Spencer, Maioris dictæ villæ, et omnium discretorum virorum dicti majoris consultorum, ego, Robertus Ricart, ex tunc ibidem communis clericus electus a Festo sancti Michaelis Archangeli, anno regni regis E. quarti post conquestum decimo octavo, istum librum incepi, composui, et conscripsi de diversis croniclis, consuetudinibus, legibus, libertatibus, ac aliis memorandis et necessariis diversis, ad perpetuam rei memoriam inviolabiliter observandis.

\section{Assit principio Sancta Maria meo, Amen.}

Jhesus, sacri ventris fructus,

Fo. $1 a$.

$\dagger$ Pie matris prece ductus,

Sit michi via, dux, eductus

$\dagger$ Libenter in hoc opere. Amen.

* At the head of this Latin prologue is a curious drawing, partly coloured in with red and green, which seems to represent the Virgin Mary seated on a throne under a starred canopy, near her an angel standing with a trumpet, while two other figures may be thought to mean the infant Jesus, and the Father looking upon him from the clouds. In the foreground is the figure of a woman kneeling to stir a pipkin which stands on a trivet over a small fire, the floor being covered with a chequered pavement. The whole is somewhat rough in its design and execution, though the dress and throne of Mary display some detail.

$\dagger$ These lines are written in red ink.

CAMD. SOC. 
Thanked be the highe name of oure Lorde and sauiour Criste Jhesu, excellent glorie and eternall reuerence to his blessid moder Seinte Marie, honoure, laude, and due preisinge be to all the Saintes of Hevyn. For asmoche as this noble and worshipfull Toune off Bristowe is holde of oure souueraigne lorde the kinge in Frank burgage and withoute mesne, by reason of his langable of the same, ${ }^{*}$ and is founded and grounded upon fraunchises, libertees, and free auncient customes, and not vpon comen lawe, as it is affermed and ratefied bi oure olde chartres, in as free and semblable wise as is the Citee of London. For the whiche the grete Chartre of Englonde callid Magna Carta will that the Citee of London and all other citees and townes fraunchised holde and kepe theire fraunchises, libertees, and free auncient custumes safly vnblemisshed, $\uparrow$ as tyme oute of mynde it hath be graunted bi the noble progenitours of oure moost dradde souveraigne lorde the kinge, and by his good grace confermed vnto the saide worshipfull Toune in so large wise, that for

* That is, the burgesses of Bristol held the land of their town direct from the Crown, without any middle lord, by the service of land-gable ("per servitium landgabul, quod reddant.infra muros") as their charter of 36 Hen. III. (A.D. 1252) puts it. (Seyer's Charters of Bristol, p. 18; see also Migne's Lexicon Mediæ Latinitatis, $v$. Burgagium.) The land-gable (A.s. land-gafol) seems to have been a certain sum payable on each house or holding, in the nature of a ground rent. In Domesday Book the returns for three places mention land-gable, those for Cambridge, Huntingdon, and Lincoln. In Lincoln, Tochi son of Outi has on each of his 30 houses " unum denarium, id est Land-gable." Goisfrid has the same on " $\mathrm{j}$. mansionem extra murum." For Cambridge and Huntingdon, only the total sums arising from this source are given; "vij. lib. et ij. oræ et duo den." for the former, and "x. lib." for the latter. Spelman says that the land-gable was generally a penny tax on each house. In the Domesday of St. Paul's (A.D. 1222, only thirty years earlier than the Bristol charter of Hen. III.), several individual payments of landgavel by tenants of the manors are named. (Hale's ed. Camd. Soc. Notes, pp. lxix. 56, \&c.) In a deed preserved with others in the church of All Saints, Bristol, an obolus of silver a year for Landgable was reserved out of $a^{\circ}$ grant, by Ric. de Mangotsfield, of land in Bristol.

The payment of land-gable in Bristol is not noticed in Domesday Book.

† Cap. ix. of Magna Carta of 9 Hen. III. This chapter stood throughout the several editions of John and Henry III. 
to shewe or expresse it in certeyn it passith mannes mynde to remembre it. For the whiche tho worshipfull and auncient fadirs that purchased the same, I can no more say for them that nowe lieth in cheste, But pray to God sende theire sowlis goode reste. Amen.

Therfore nowe in maynteyneng of the said fraunchises herafter more duely and freely to be executed and excercised, and the perfaitter had in remembraunce, the right honourable famouse and discrete personne William Spencer, as nowe beinge Maire of this worshipfull Toune of Bristow, in the xviijth yere of the full noble reigne of oure moost dradde souueraigne lord kinge Edward the fourth, hath commaunded me, Robert Ricart, the same yere electid and admitted into the office of Toune Clerk of the saide worshipfull towne, for to devise, ordeigne, and make this present boke for a remembratif evir hereaftir, to be called and named the Maire of Bristowe is Register, or ellis the Maire is Kalender. In the whiche boke is and shalbe enregistred a grete parte of the auncient vsages and laudable custumes of the saide worshipfull towne, tyme oute of mynde vsed and excercised in the same. Whiche boke in substaunce shal rest upon vj principall matiers.

\section{Primum Principale.}

The first to shewe by cronicle the begynnyng and furst foundacioun of this saide worshipfull Toune of Bristowe, whiche was here furst sett and billed vpon a litill hille by twene iij. yatis, scilicet, Seinte Nicholas yate, Seinte Johnes yate, Seint Leonardis yate, and the newe yate, bi that noble prince Bryneus, brother vnto $K_{y n g}$ Bellynus, tofore Thencarnacioun of Crist by recorde of Brutes cronicles. And of al the kynges that were in Englonde affore the Conquest, conveied in a bregement with the yeres of theire reigne, and how many of them were kinges anoynted. 


\section{Secundum Principale.}

The secunde to shewe how many kinges haue bene sith the Conquest, and how the Castell of Bristowe was furst sett and billed, and by whome. The Abbey of Seint Austynes founded, and bi whome. And howe aftirwardes this worshipfull Toune hathe be enlarged, fraunchised, and corporated, by whate kinges daies, and by whoos sute and coste. The laboure, peyne, and travaille of the saide sewtours Almighty God rewarde them in hevyn, for al we ar bounde to pray for the same.

\section{Tercium Principale.}

The thirde to shewe who was the first Maire made and charged in this worshipfull Toune of Bristowe, the first yere of the reigne of Kinge Herry the thirde, sonne vnto Kynge John, that moost freest and moost largiest enfraunchised this worshipfull Toune; whiche Kinge Herry hielde the grete Counceille here in Bristowe,* sone aftir his Coronacioun at Gloucestre, the first yere of his reigne, beinge with hym the same tyme the Pope's Legat Gualo with many lordes spirituall and temporall. And how many Maires haue been sithen in this worshipfull Towne. And whate actes and gestes hath happened to be donne in euery Maires yere, abregged bi cronicle vnto this present yere and tyme of this boke makinge.

\section{Quarifum Principale.}

The fourth to shewe howe thonnourable Maire, Shireef, Baillyfs, and other officers of this worshipfull Toune yerely been chosen and charged, and of thexecutinge of theire offices duringe theire yeres.

* It was at this Great Council (A.D. 1216) that the first and provisional confirmation of Magna Carta was made, speedily to be followed by a second within a year. Blackstone's Magna Carta, Introd., pp. xxvii., xxxiv., xxxix. 
In especiall of the grete hedde Officer, Maire of Bristowe, owre souueraigne lorde the Kinges lieftennaunt and oure Alther Maistir for the yere beinge, in whome must rest the grete substaunce of poletyk prouisioun, wise and discrete guydinge and surveyeng of all officers and others dependinge, concernynge the comune wele of the hole body of this saide worshipfull Toune and procincte of the same. Quoniam in ipso et per ipsum et ad ipsum omnia, etc. Wherfore we al ar bounde hertilly to praie God for to preserue him, helpe, assist, and counsaille hym, that so diligently with grete instaunt coste and laboure shall apply hym to entende the honnoure, welth, and prosperitee of this noble Towne and of al the inhabitauntis of the same.

\section{Quintum Principale.}

The $\mathrm{v}^{\text {th }}$ to shewe by Kalender where and in whate Bookes a man shall fynde, rede, and see many and diuerse fraunchises, libertees, aunciant vsages and customes, with other actez, ordinauncez, composiciouns, and constituciouns, of tyme out of mynde eunated and stablisshed in this worshipfull Toune, by auctoritee of their olde chartres graunted them of the noble progenitorz of our souveraigne lorde the Kyng, and by his good grace confermed, givinge them power and auctoritee so to doo. And in whate places, bokes, and levis the premisez and euery of them may be founde with a wete fynger.*

\section{Sextum ét ultinum Principale.}

The sixte and the last Principalle. Forasmoche as this worship-

* The plan so full of promise sketched out by Ricart in this preface was not, as will be seen, entirely fulfilled, especially in the Third and Fifth Parts. In the Third Part long series of years are passed over with only the record of the mayor and officers for each year, none of the "actes and gestes" done in their time being mentioned. In this Fifth Part also the hope of what might be found by the help of the "wete fynger" is much disappointed. 
full Toune of Bristowe hath alweis vsed comenly to execute his fraunchisez and libertees accordinge in semblable wise as the noble Citee of London hath vsed, and a grete parte hath take his president of the said Citee in exerciseng the same: It is therfore necessary and conuenyent to the officers of this worshipfull Toune of Bristowe for to knowe and vnderstande a parte of the auncient vsages of the saide noble Citee, whiche shalbe shewid them in the $\mathbf{v j}^{\text {th }}$ principalle by a boke that was sometyme belonginge to that worshipfull personne, Henry Daarcy, Recorder of that noble Citee of London in Edward the thirdes daies.*

\section{Encipit primum principale a cronicula $\mathbf{H}$ rute.}

[This First Part consists in the MS. of folios $0 b$ to $19 a$, and contains the history of Britain from Brute to the defeat of Harold by William the Conqueror. Ricart himself says it is " a cronicula Brute," and he appears to have followed Geoffrey of Monmonth as far as Constantine, the successor to King Arthur. In his abridgement from this author he has made several variations, omitting certain names altogether, and altering others, as Aurylambros for Aurelius Ambrosius, Donebaude for Dunwallo Mulmutius, Corynbatrus for Gurgiunt Brabtruc, \&c. Ricart often gives the number of years a king reigned where Geoffrey does not, the figures seldom agreeing even in those cases in which Geoffrey gives them.t It is curious ton that though Geoffrey accounts, after his fashion, for the founding of many towns in Britain, he does not once mention Bristol, although his history was dedicated to that very Robert Earl of Gloucester who played so important a part in the annals of the city. Ricart, however, was an apt pupil, and, not to suffer his famous city to be behind others in antiquity, he introduces the building of Bristol by Brynne, one of the British kings.

The chronicle is carried on briefly, and somewhat imperfectly, after Constantine, through the Saxon and Danish kings; there does not occur anything in it very noteworthy, beyond the quaint style of narration. Alfred the Great is disposed of in a few lines : after telling how Hungar and Hubba had " scomfited dinerse kinges," and that he had prevailed against them, it is simply added that "this kyng Alured

* Ricart here makes an error, which he afterwards repeats. Henry Darey was mayor, not recorder, of London in 1337 and 1338, nor was there a recorder of that name during the reign of Edward III.

$\dagger$ Dr. Giles's edition in "Six Old English Chronicles," Bohn's Library, 1848, is the one that has been here referred to. 
was a noble kyng, and the first kyng anoynted that euer was in this londe."* Much more detail is given relating to Knought (Canute), and the descent of the Empress Mand from the banished son of Edmund Ironside.

Immediately following this First Part, after the rubric "Expliciunt Cronicule ante Conquestum," are some quaint leonine verses, on the character or actions of the kings of England, from Alfred to Henry VI., with the number of years that each reigned placed in the margin. $\dagger$ Ricart has then inserted here, perhaps not finding it to fit in with the chronicle of Brute, a short account of the founding of the church of Glastonbury by Joseph of Arimathea, and of its after history. The first passage of this, from the words "ex quo" to " testantur" (see after, p. 13), may be found, with a few formal variations, at the end of a short piece, "De Joseph ab Arimathia," which occurs in two manuscripts in the British Museum, $\ddagger$ and of which the first portion is from an author named Malkin, quoted by John of Glastonbury. (Part of this passage, slightly different, is also printed in Capgrave's " Nova Legenda Angliæ," fol. 263a, col. 2, and, from the Records of Glastonbury, as quoted by John of Tynemouth, in Archbishop Ussher's "Britannicarum Ecclesiarum Antiquitates," Dublin, 1639, p. 18.) The remainder agrees with the account given by John of Glaston-

* This popular belief appears to have been a mistaken one : records of earlier unction of English kings being in existence. See Taylor's "Glory of Regality," pp. 232, 233.

† In a MS. volume in Heralds' College (Arundel, vol. 48, fo. 99), which contains a collection of historical scraps and compilations made by William Botoner [otherwise Worcester], occurs another version of these verses in his hand. A considerable part of the volume has been printed by Hearne at the end of the "Liber Niger Scaccarii:" these verses are there included in the portion to which Hearne has given

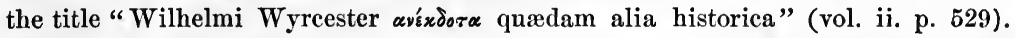
The two versions differ much ; some of the lines are altered in whole or in part, and Ricart has omitted several of the lines given by Botoner, who begins with Ethelbert and Ethelred: the two are, however, both evidently taken from the same original, even to the repetition in both of a few doubtful readings. There is nothing to shew that Botoner was their author, beyond the fact of their being found in his commonplace book : it is not improbable; but, whether he were so or not, he and Ricart were in all probability on good terms, as mentioned in the Introduction, and hence perhaps the appearance of the lines in Ricart's book. Six of these lines are quoted, but incorrectly, by H. Rogers, in a small book, entitled, "Calendars of $\mathrm{Al}$ Hallowen," Bristol, p. 170.

$\ddagger$ MSS. Arundel. 220, fol. 274; Cotton. Titus, $\overline{\mathrm{D}}$. vir. fol. 30. The first passage above cited has been printed by the Rev. W. W. Skeat-to whom I am indebted for pointing the MSS. out to me-in his "Joseph of Arimathie " (Early-English Text Society, 1871), p. 71. 
bury,* and also with that given by Capgrave in his Life of St. Patrick. $\dagger$ Ricart, therefore, may have made up his account from the works of John of Tynemonth and John of Glastonbury, or possibly he may have had access to the then recent work of Capgrave, who appears to have made use of these authors, and have made an abridgment from it. It is, however, against this latter view that the passage from "ex quo" to "testantur" is not given in its entirety by Capgrave.

"Notabilia diversa" of the dates of some events of importance in the ecclesiastical history of England, the founding of certain religious orders and monasteries, \&c. naturally follow the account of the origin of the British Church, thongh what rule of selection guided the scribe it is not easy to discover.

The first few pages of the Part are here printed in order to bring in the fancied bnilding of Bristol; it also serves to show Ricart's style of rendering Geoffry. The three additions above described complete the extracts from the First Part.]

Fol. 3b. For asmoche as it is righte convenient and accordinge to euery Bourgeis of the Towne of Bristowe, in especiall thoo that been men of worship, for to knowe and vnderstande the begynnyng and first foundacion of the saide worshipfull Toune: Therfore let him rede the olde Cronycles of Brute, and he shall fynde howe sone after that Brute had sette and billed the Citee of newe Troie, whiche nowe is London, in remembrans of the grete Troie that he and all his lynage came fro. Then Brute reigned $\mathrm{xx}$ winter and more, and was beried in the newe Troie. And he had iij manly men to sonnes, Lotryn, Albanac, and Kambor. Brute ordeigned Lotryn to be Kinge of this londe called the grete Britaigne, Albanac Kinge of Scotlonde, and Kambor Kinge of Walis. And after the decees and occisioun of Lotryn and Albanac, reignid Madhan $\mathbf{x x x}^{\mathrm{ti}}$ yere. And after Madhan, regnid Memprys xxij yere. And aftir Memprys regnid his sonne Ebrac lx yere, a noble prince and a manly, whiche by his prowesse and manhode and with the help of his Bretonnes conquerid al fraunce and gete there grete richesse; so that when he came home he made and billed a noble citee and callid it aftir his name Eborac, that now is Evirwyk, alias Yorke. And also he billed the castell of Maydens, whiche is Edenburgh in Scotlande.

* Johannis Glastoniensis Chronica, ed. Hearne, pp. 58-60, 66.

+ Nova Legenda Anglix, fol. 263a, col. 2, to 264a, col. 1. 
And aftir this Ebrac regned his sonne Brut Greneshall $\mathrm{xxx}^{\mathrm{ti}}$ yere. And aftir him reignid kinge Leile, whiche bilde the citee of Carleil; in whoos tyme king Salamon reigned in Jerusalem, whiche billed the Temple of our Lorde. And after this king Leil reignid his sonne Ludludubras xiij yere, whiche bield the citeis of Winchester and of Caunturbury. And after this kinge Ludludubras, reignid his sonne Bladud xxj yer, a grete nigremancier, whiche bilde the citee of Bathe and devised ther the hote bathes. And after this kinge Bladud reignid his sonne Leire, whiche billed the toune of Leicestir and called it aftir his name. And sone aftir this kinge Leire, bi occasion of grete werres the lande was departid in foure; that is to say, Englond to one Dowalyn, Scotland to oon Scater, Walis to one Rudak, and Cornewaile to one Cloton. This Cloton by juste title was right heire to all these landes, and he had a sonne highte Donebaude. * * * This kinge Donebaude had ij manly men to sonnes, that one Belyne, and that other Brynne, whiche aftir the decees of their fadre departed the londe bitwene them as their fader had commaunded and ordeignid. That is to say, Belyne the eldest sonne had al the londe a this side Humbre, and Brynne had all the londe beyonde Humbre vnto Scotlonde. And for asmoche as Belyn had the more parte and the better parte, Brynne wexed wrothe and wolde haue had more; but Belyn wolde not suffre him, so they beganne to werre; but Brynne the yonger broder had no force nothir pouer against his brother Belyne, so Brynne, by counceille of his people, voided into Fraunce and there abode long tyme, and gete there grete lordeshippes by mariage, for he was Duc of all Burgoynhe, by that he wedded the doughtir of Duc Selbyn, whiche was heire of all that londe. And whiles Brynne bode in Fraunce King Belyn regnid nobly and in peace in this lande amongest his Bretonnes, and made iiij Roiall weies through all the londe; that one from the Este vnto the West that is callid Wattelingstrete, and that other wey from the Southe vnto the Northe that is callid Ikeneldestrete. And CAMD. SOC. 
other two waies he made a twhert the lande, that one is callid the Fosse, and that other the Fossedyke; * and maynteigned well the lawes that his fadre Donebaude had stablisshid in his tyme.

And in this meane tyme Brynne assembled a grete pouer and a grete oste of Burgoinhers and Frensshmen, and came in to this lande to fight with his brother Belynne. But they were made accorded bi their modre Conswenner with grete instaunce and labour. And then they came to giders with grete joie to the citee of Newe Troy, and there dwellid in fere a hole yere; and then they enterprised and toke upon them for to go conquere al Fraunce; and so they ded, and passid then to Rome and conquerid all Rome, Lumbardie, and Germanye, and toke homages and feautees of Erles, Baronns, and of al other estatis of that lands-bi whome Kinge Arthure toke his title in all his conquestis. And aftir they had this doon the saide two brethern retorned home in to this lande of Grete Bretaign, with theire Bretonnes, and dwellid here to giders in grete joye. And then Brynne first founded and billed this worshipfull Towne of Bristut that nowe is Bristowe and set it vpon a litell hill, that is to say, bitwene Seint Nicholas yate, Seint Johnes yate, Seint Leonardes yate, and the Newe yate. And nomore was bilde not many yeres after. And thenne Brynne repaired home ovir see in to his oune Lordeshippes of Burgoyne and there abode al his lyf. And Kyng Bellyne abode at Newe Troy, and bilde there a noble yate fast by the watir of Tamys, and callid it Bellyngesgate aftir his oune name; and reignid nobly all his lyf, and lieth at Newe Troye.*

* $\quad * \quad * \quad * \quad * \quad * \quad * \quad *$

\section{Expliciunt Cronicule ante Conquestum.}

Immediately after these lines, and filling up the rest of the page, is the plan of the city, of which a facsimile (original size) is given in the opposite plate. A late copy of this plan is to be found in Seyer's History of Bristol, vol. i. p. 263, and another, very ill executed, in H. Rogers's Calendars of All Hallowen. 


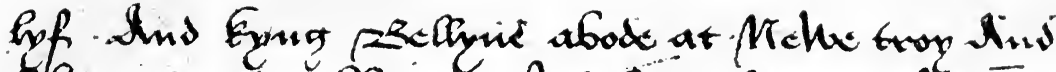

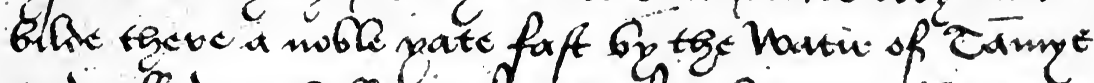

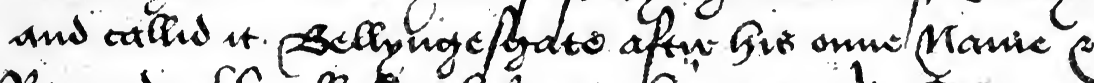

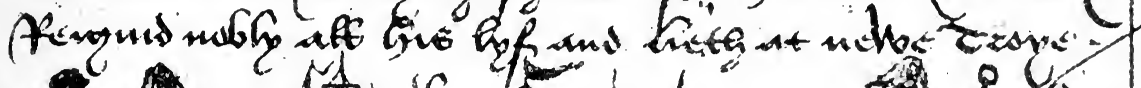
4. (1)

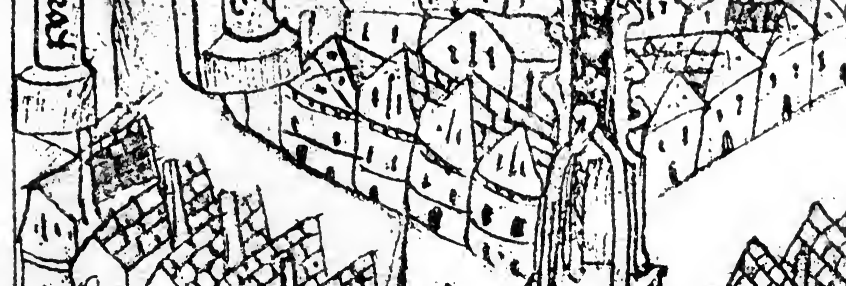
Ju No

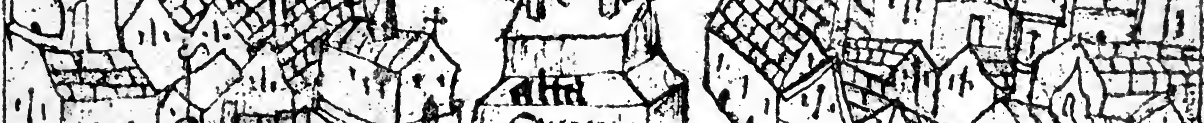
(16) 


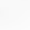


Fo. 15b. These verses folouyng shewith howe many kinges anoynted haue been in Englond as well before the Conquest as sithen:-

Rex Aluredus.

Edwardus.

Ethelstanus.

Edmundus.

Edredus.

Edwynus.

Edgarus.

Edwardus.

Etheldredus.

Edm̄undus.

Knuto.

Harold'.

Hardknutus.
Rex Aluredus erat primus Rex Angligenarum

Unctus qui fuerat, docet ut liber historiarum.

Septem pontifices Edwardus Rex stabilivit;

Belli multiplices sudores ipse subivit.

Magnus Ethelstanus Wallenses suppeditavit,

Et robusta manus ejus Scotos superavit.

$\mathbf{x x x}$ annos.

Rex Edmundus erat feriente latrone necatus,

Ultio non deerat, jugulans fuerat jugulatus.

Edredus meruit discedere morte beata,

Colitus illa fuit Dunstano notificata.

xxiij

Xv

vj

ix di.

Edwynus extiterat juvenis petulans et iniquis, ${ }^{*}$

Dunstano fuerat rex iste ferox inimicus.

iiij

Princeps præclarus, constructor cœnobiorum

Extitit Edgarus, et carus amator eorum.

Dira noverca fuit Edwardo qui sitiebat $\uparrow$

Quæ potum tribuit, dedit oscula, post perimebat.

Sacra statim natus Etheldredus violavit,

Non baptisatus baptisterium maculavit.

xvij

Edmundus justus, audax, patiens, moderatus,

Corpore robustus fuit, Yronside vocitatus.

xij di.

ix

$\mathbf{x x}$

Knuto fuit Danus, pater ejus nomine Svanus, $\ddagger$

Sævus et insanus fuit, $\S$ atque prophanus.

XX

Haroldi nomen regis reticere $\|$ nequimus,

Ejus cognomen Harefote fuit, ut reperimus.

iij

Gratum successum rex Hard[a]knutus habebat,

Qui post discessum fratris diadema gerebat.

* Sic in both MSS.; see before, p. 7.

+ sciciebat in original.

$\mp$ Sevanus in original.

$\S \mathbf{A}$ word seems to be omitted here, the metre being defective.

\| rex reficere in original.

C 2 
Edwardus.

Haroldus.

Willelmas bastard.

Willelmus

Rufus.

Henricus clerc.

Stephanus.

Henricus.

Ricardns.

Johannes.

Henricus.

Edwardus.

Edwardus

Carnarvan.

Edwardus

Wyndsore.

Ricardus.
Rex et virgo fuit Edwardus, qui numerari

Cum Sanctis * meruit in* celis glorificari. xxiij annos.

Vulnus sustinuit Haroldus congrediendo,

Sceptrum deseruit et vitam mox moriendo.

\section{Hic omnes añte Conquestum.}

Viribus armorum Bastard Willelmus agebat,

Ut Rex Anglorum fieret, jus hocque volebat.

Grata sagitta fuit Willelmum qui perimebat,

Dira morte ruit qui dira frequenter agebat.

Henrici regis discretio grata patravit

Oblitæ legis moderamina dum renouavit.

$\operatorname{xxxvj}$

Ad regimen terræ Stephanus male qui veniebat,

Non expers guerræ, sceptrum regni retinebat.

xix

Hic est Henricus sub quo passus reperitur

Præsul magnificus Thomas gladio que feritur. $\quad \quad x x x v j$

Hic fert, ut didici, Ricardus Rex Saladinum,

Nullius medici sanaret cura supinum.

$\mathbf{x}$

Quis dolet aut doluit de Regis morte Johannis, Qui nulli placuit et vixit pluribus annis.

xvj

Rex Henricus constructor cœnobiorum,

Princeps pacificus, operum factorque piorum.

$\operatorname{lvj}$

Scotos dum vixit Edwardus suppeditavit,

Illos $\uparrow$ afflixit, tenuit, pressitque laniavit.

$\mathrm{XXXV}$

Carnarvan natus Princeps Edwardus amatus

Ingratis gratus est, morte gravi cruciatus.

xix

Armis militiæ Rex Edwardus vacat iste,

Nec fruitur requie ; tantum regem rege, Christe!

Principis egregii Ricardi jure secundi

Vix cadit eximii ; $\ddagger$ fallax est gloria mundi.

$\mathbf{x x i j}$

* Sanctus and et in original.

$\dagger$ Wallos in Botoner's MS.

$\mp$ Sic. 
Henricus iiijtus. Nobilis Henricus quartus, pietatis amicus, Belliger invictus, bellorum vicerat ictus.

xiiij annos.

Henricus $v^{\text {tus. }}$ Henricus quintus, quo nemo sanc $[\mathrm{t}]$ ior intus,

Ecclesiæ factor et militiæ fuit auctor.

$\mathrm{x}$

Est verus textus, princeps collegia fundans,

Henricus sextus est moribus almus abundans. $\quad$ xxxviij

[A blank page here intervenes.]

Fol. 17b.

The first place founded of oure Lady was in Avalone that nowe is Glastonbury, as shewith folouyng:-

Ex quo Apostoli divisi erant in diversas regiones ad prædicandum verbum vitæ. Sanctus Philippus Apostolus sortitus est in regionem Fraunciæ cum suis discipulis, de quibus misit in Britanniam xij cim, quorum primus erat Joseph ab Arimathia, qui et Dominum sepelivit, anno ab Incarnacione Domini lxiij ${ }^{\circ}$, et ab Assumpcione Sanctæ Mariæ $x^{0}$ : quibus $x i j$ hidæ* a paganis regibus ibidem inventis $\uparrow$ erant concessæ et confirmatæ. Qui ibidem commorantes, per Gabrielis Archangeli admonitionem ecclesiam in honore Sanctæ Mariæ, ex virgis torquatis muros perficientes, construxerunt, anno a Passione Christi xxxj $^{\circ}$. Quam quidem ecclesiam Dominus noster Jhesus $\ddagger$ Christus in honore suæ matris presentialiter dedicavit, et idem Joseph ab Arimathia cum filio suo Josepvo et ceteris suis sociis ibidem vitam suam finisse $\S$ multi testantur. Anno graciæ - $\mathbf{C v j}^{\text {to }} \|$ sancti prædicatores Faganus et Clebanus $\mathbf{T}$ regnante in Brittannia Lucio Rege per Eleutherium Papam missi, dictum regem cum tota fere sua gente sacro fonte abluerunt, qui [per] partes Britanniæ*** in insulam $\mathrm{A}$ vallacione $\dagger+$ venerunt, et ibidem antiquam prædictam ecclesiam invenientes deuotissime per ix annos in Dei laudibus conversati sunt. Fluxerunt itaque ab adventu discipulorum sancti

* hidas in original.

$\dagger$ inventi in original.

$\ddagger J$ ' $e$ in original.

$\S$ fuisse in original.

\| The scribe has here made an error ; clxvj is the date meant.

I This name is variously given by Capgrave, \&c. as Duvanus and Deruvianus.

** Bruitanie in original.

t+ The isle of Avalon. 
Philipi ut præmittitur usque ad adventum dictorum Fagani et Clebani ciij anni. Qui in memoriam primorum xij ex sociis suis xij eligerunt et in præfata $*$ insula, rege Lucio consenciente, habitare fecerunt; qui postea in eisdem locis in quibus primi xij cim præmissi $\uparrow$ habitaverant. Sicut anacoritæ $\ddagger$ usque ad adventum sancti Patricii successive manserunt; in vetusta tum ecclesia ad divina obsequia devotius complenda crebro convenierunt. Anno ab incarnacione Domini ccccxxxiij sanctus Patricius, postquam Hiberniam ad fidem Christianam convertisset, Brittanniam reversus et insulam A vallone ab anacoritis ibi inventis in illorum Abbatem est electus, quibus omnibus in unum locum congregatis in optima conversatione per xxxix annos ibi permanens, anno ætatis suæ $\mathbf{C x j ^ { 0 }}$ finivit vitam suam. A tempore cujus usque ad Berwald $\S$ abbatem de Anglis primum fluxerunt anni cCxxxvij, per quod tempus fuerunt Glastoniæ plures.

\section{HiC SEQU[U]NTUR NOtabilia DIVERSa.}

Fo. 18a. Anno graciæ lxiiijo constructa est primo a discipulis Sancti Philippi Capella Britañ regni in honore suæ genetricis dedicata, in Insula Avaloniæ, ut superius recitatur.

Anno graciæ DCccCxxxiij fundata sunt Monasteria de Midd' [Middleton] et de Muchelneye.\|

Anno graciæ DCCCclxj fundatum est Monasterium de Tavestochiæ.

Anno graciæ $\mathbf{M}^{\circ} \mathbf{x x x v j}$ ๆ incepit ordo Cartusiensis sub Vrbano Papa.

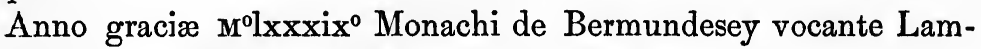
franco Archiepiscopo venerunt primo in Angliam.

Anno graciæ $\mathbf{M}^{0} \mathrm{lxxxxviij}$ Cistertiensis Cænobium inceptum est, et eodem anno incepit Ordo Cistertiensis.

* prefatis in original.

$\uparrow$ premiti in original.

$\ddagger$ anacoriti in original.

§ The first English abbot; in 690 he was made Archbishop of Canterbury.

II See the notes as to the dates of these foundations in Tanner's Notitia, ed. 1787.

T This date is variously given in different authors as 1080,1084 , and 1086. 
Anno graciæ $\mathbf{M}^{\circ} \mathrm{C}^{\circ} \mathrm{vj}^{0}$ constitutus est Ordo Canonicorum Sanctæ Mariæ de Southwerk, London.

Anno graciæ $\mathbf{M}^{0} \mathbf{C}^{0} \mathbf{X v i j}$ incepit Ordo Templariorum. Anno graciæ $\mathbf{M}^{\circ} \mathrm{C}^{0} \mathbf{x x j}{ }^{0}$ fundata est Abbatia de Redyng.

Anno graciæ $\mathbf{M}^{\circ} \mathbf{C}^{0} \mathbf{X x v i i j}{ }^{\circ}$ confirmatus est Ordo Templariorum $a b$ Honorio Papa, et a Stephano Jérosolimæ Patriarcha.

Anno graciæ $\mathbf{M}^{\circ} \mathbf{C}^{0} \mathbf{X x x j ^ { \circ }}$ fundata est Abbatia de Tintarn.

Anno graciæ $\mathbf{M}^{\circ} \mathbf{C}^{\circ} \times \mathbf{x} x \mathrm{j}^{\circ}$ Septimo Idus Maij fundata est Abbatia de la Quarer in Anglia. Et vj ${ }^{\text {to }}$ Kalendas Januarii eodem anno fundata est Abbatia de Fontibus.

Anno graciæ $\mathbf{M}^{\circ} \mathrm{C}^{0} \mathrm{Xx \times vj} \mathbf{j}^{0}$ quinto nonas Maii fundata est Abbatia de Forde.*

Anno graciæ $\mathbf{M}^{\circ} \mathbf{C}^{\circ} \times \mathbf{x x i x ^ { \circ }}$ tertio Idus Novembris fundata est Abbatia de Kyngeswod.

Anno graciæ $\mathbf{M}^{\circ} \mathbf{C}^{0} \times{ }{ }^{2} j^{\circ}$ fundata est religio Canonicorum regularium in ecclesia de Brutone.

Anno graciæ $\mathbf{M}^{\circ} \mathrm{C}^{\circ} \mathrm{Xxxj}^{\circ}$ fratres de Cartusia ingressi sunt habitacula sua in Anglia.

Anno graciæ $\mathbf{M}^{\circ} \mathbf{C}^{\circ}$ lxxxiiij ${ }^{\circ}$ Glastonia cum Abbatia fere tota combusta est.

Anno graciæ $\mathbf{M}^{\circ} \mathrm{C}^{0} \mathbf{X x x x v j}{ }^{0}$ Episcopus Bathoniensis et Wellensis nomine Savarico a rege Ricardo optinuit patronatum Abbatiæ Glastoniensis per Cartam Regis Ricardi concessum in augmentationem Episcopatus sui. Et sic adunatæ sunt ecclesiæ Bathoniensis et Glastoniensis, quam quidem adunationem Celestinus Papa confirmavit.

Anno graciæ $\mathbf{M}^{\circ} \mathrm{CC}^{0} \mathrm{vij}^{\circ}$ Fratres Minores, $\uparrow$ favente Papa Innocentio, emergentes terram repleverunt, habitantes in urbibus et civitatibus, nichil omnino possidentes, de Evaungelio viventes, spontaneam pau-

* This house was founded at Brightley in 1136, and was removed to Ford in 1141.

$\dagger$ There is some error about this date; Pope Innocent approved the rule of the Minor Friars in 1210, and they are said to have come into England in either 1219 or 1224. (See Tanner's Notitia, pref. p. xiii.) See next paragraph, which agrees with the date given by Eccleston (Monumenta Franciscana, Rolls ed. p. 5.) 
pertatem pretendentes, cincti vinculis sive funiculis, nudis pedibus euntes, \&c.

Anno graciæ $\mathbf{M}^{0} \mathrm{CC}^{0} \mathrm{xxiiij}{ }^{\circ}$ nono Calendas Septembris fratres Minores venerunt prius in Angliam.

Anno graciæ $\mathbf{M}^{\circ} \mathrm{CC}^{0} \mathbf{X x v}^{\text {to }}$ confirmata est Regula fratrum Minorum ab Honorio Papa.

Anno graciæ $\mathbf{M}^{\circ} \mathrm{CC}^{0} \mathbf{x} \times \mathbf{x i j}^{0} \dagger$ obiit frater Franciscus, primus Magister ordinis Minorum.

Fo. 20b. NowE SETHEN IT HATH BE SHEWED in the first principall of this Boke the foundacioun and first begynnyng of this worshipfull Toune of Bristowe to fore thencarnacion of Crist, set as it standith vpon a lytill hill bitwene iiij yatis; and also shewid you all the kinges tofore the Conquest, and how many of them were kinges anointed, and of the yeris of theire reigne: And must now procede on the secunde principall of this boke, shewinge al the kings sethin the Conquest, and of theire actis. And howe this worshipfull Toune

$\triangle$ hathe be enlargid, fraunchised, and corporatid, and bi whome; bigynneng at William Conqueroure, Duc of Normandie, whiche was the vijth Duc that euer was in Normandie. For in the cronicles of Fraunce I finde the first Duc that was of Normandy, it was Duc Rollo le fort, and he was a Saresyn + come oute of Denmark into Fraunce, and chased the kinge of Fraunce with so grete werris and bataillez that the kinge was fayne to make peace with him; and accorded in this wise, that the kinge of Fraunce yave him his doughter to wife and all the Duchie of Normandy with her in mariage. And then became Rollo a Cristen man, and was called Robbert, and was the first Duc that euer was of Normandy. Wil- .

* This date should be 1223, according to Stevens's Hist. of Abbeys, vol. ii. p. 6; 1224 according to Eccleston.

$\dagger$ This date should be 1226. (See Stevens, as before.).

$\ddagger$ Sic. 
liam Longspee was sonne to Rollo, and the secunde Duc; Richard Saunzpouer was sonne to William, and the third Duc; Richard the Seconde was sonne to Richard, and the fourth Duc; Richard the Third was sonne to Richard, and the $\mathrm{v}^{\text {th }}$ Duc; Robert was sonne to Richard, and the vj ${ }^{\text {th }}$ duc. William Bastard was sonne to Robert, and the vijth Duc of Normandy. This William Bastard conquered all Inglonde, and his issue succesid enjoied and possessid the same, as shalbe shewid here folouyng.*

\section{Encipit secunoum principale buius libri a cromquestum.}

Fo. $21 a$.

[The intent of the second Part, as regards Bristol, is shown in the prologue (before, p. 4), and in the paragraph above. It carries on the general history from the Norman Conquest, 1066, till the death of John, occupying forty leaves (fos. $20 b$ to $59 a$ ). It mainly consists of a yearly chronicle of events, political, ecclesiastical, and general, and is for the most part translated and abridged from the Chronicle of Matthew of Westminster, in many places following his language very closely. A few passages bear traces of the writer's having had recourse to other sources, among which Roger of Wendover may have been one ; be also inserts here and there facts relating to ecclesiastical affairs not to be found in his original. But we find less allusion than might be expected to the share that Bristol had in past affairs, or to the illustrious personages who were at times within her walls, little in fact beyond the imprisonment of King Stephen in the Tower of Bristowe in 1140, and the imprisonment and death in the Castle of Eleanor, sister to Arthur, and niece to King John.† The death of Robert Earl of Gloucester, "the whiche billed the Castell of Bristowe," is recorded, but little is said of the part taken by this powerful noble in the war in support of his sister the Empress Maud. In regard to the foundation of some of the religious houses in and near Bristol, however, Ricart had probably more means of information, and, accordingly, at the end of William the Conqueror's reign he inserts some memoranda as to some of them, which introduce several historical characters. At the end of the reign of John, who was lord of the honour of Bristol in right of his first wife, Isabella, the grand-daughter of Robert Earl of Gloucester, Ricart stops to enlarge upon the privileges confirmed

* On the opposite page, being folio $21 a$, is the picture of William Conqueror. (See Introduction.)

$\dagger$ The Chronicle of Thomas Wikes, which is the authority for the confinement of Eleanor, does not mention the place, nor the fact of her death in prison. See also Seyer's Memoirs of Bristol, i. 525.

CAMD. SOC. 
to the citizens of Bristol by John's charter to the town, and by subsequent confirmations of charters.

The portions here given are those which relate to the religious houses and the town of Bristol, with two or three incidents which seemed worthy of being extracted from the general history.

Within this Part are included seven portraits of kings, described in the Introduction.]

F.o. 26a. Be it remembred that kinge William Conqueroure, after the decesse of his qwene Dame Mawde, bi assent of his son William Rufes that succedid him kinge, in the yere of oure Lord God Mlxxxiiij. thonnoure of Berton frely he yave vnto the lorde Robert son of Haymon, whiche came with him oute of Normandy into Englond, whiche Robert, at thenstaunce and excitacioun of his wif, Dame Sibille, bi grace of the Holy Goost he founded of the newe, and newe billed, to the worship of God, and of his blessid modre Seynt Mary, the churche of Tewxebury with all the howses of office of the same. Whiche Robert bigate on Sybill his wif iiij. doughters, whose names are these: furst Cecilia that afterward was Abbas of Shaftesbury; and Hawisia the same wise Abbas of Wilton; Mabilia was wedded to Robert son of kinge Harry the First, beinge Erle of Gloucestre; and Amicia was maried to the Erle of Lityll Bretaign. And the foresaide Robert son of Haymon the abbey of Crambourne with the monkes of the saide church, excepte a fewe to the Priory of Tewkesbury, for the bettir foundacioun of the place, chaunged it to an Abbey.* Whiche foresaide Priory bi certein noble Dukes callid Odda and Dodda in tyme of the olde kinges of Englond, in the worship of our Lady was first founded, in the yere of oure Lord God vijcxv. And so monkes there gaderid with londes and possessions, the saide place gretely incresid, as more playner it appierith in other cronicles. And, after the decece of the saide Robert sonne of Haymon, kinge Harry the First thonour of the

* The monks of Cranburn moved to the Abbey of Tewkesbury in 1102, after the enlargements made thcre in that year by Robert. See Leland, Itin. vi. 82; Mon. Ang. (ed. 1819) ii. 53. 
same Robert hield and kepte, the space of $\mathrm{ij}$. yere. ${ }^{*}$ And for that it shulde not be enpeyred ne abused with wrong sewtes, vsages, and customes, bi gode aduice of his counsaille the saide Kinge Harry gave the saide Robert Haymons doughter vnto Robert his sonne callid Robert Consull, $\dagger$ and made him erle of Gloucestre. The forsaide Robert sonne of Haymon levid after the decesse of William Rufes vij. yere, reignyng kinge Harry the First. The foresaide Robert Consulle, erle of Gloucestre, bylde the towre and Castell of Bristowe and the priory of Seinte James of the saide town, and the Castell of Kaerdyff. And the foresaide Robert Consulle, Erle of Gloucestre, levid in his erledome xl. wynter, and moche in the tyme of his fadre Harry the First. $\neq$ And after the decesse of Robert Consulle, succedid him his sonne and heire Erle William Consule, whiche toke to wife Hawisia, Countesse of Leycestre, and begate on her Robert, that decessid affore his fadre. And iij. doughters, that is to say, first, Mabilia maried to the Erle of Euerous in Normandy, of whome came Almaricus, whiche hielde and possessid a lytill whiles therledom of Gloucestre, and sone decessid without issue. Anothir doughtir he had callid Cecilia, which was maried to Sir Richard de Clare, erle of Hertford, of whome came my lords of Bokingham. The third doughter callid Isabell, whiche to fore her fadres decesse was maried vnto John $\S$ sonne of kinge Harry the Seconde and afterwards kinge, which Isabell decessid withoute issue. And so the noble Erle William Consule decessid in the yere of our Lord God $\mathbf{M}^{\mathrm{l}} \mathrm{cl} \mathbf{x x x i i j}$, and in the $\mathbf{x x}^{\text {th }}$ yere of the reign of Kinge

* Robert died in 1107. Henry I. also held the honour for six years after the death of Earl William, from 1183-1189.

† The writer here, evidently not understanding the foreign title of Consul (i.e. comes, earl), has used it as a surname.

\$ The greater part of the foregoing paragraph, down to this word, is quoted by Seyer, Mem. of Bristol, i. pp. 342, 349, 350.

$\S$ This is a mistake; William Earl of Gloucester died in 1183, and his daughter was not married to John till 1189. See the history of this marriage in Seyer, Mem. of Bristol, i. 496, 498-505. 
Harry the $\mathrm{ij}^{\mathrm{de}}$, and his body in the monastery of Keynsham, whiche he in remembraunce of his son Robert founded, lyeth full worshipfully buryed tofore the highe awter ther.

* And the saide Abbey of Keynesham was furst founded bi the saide Erle William Consule, in the yere of our Lord God $\mathbf{M}^{\mathrm{l}} \mathbf{c l} \mathbf{x} \mathbf{x j}^{\mathrm{D}}$. And where as it is afore reherssid that Issabell, the yongest doughtir of the saide Erle William Consule, and wife to Kyng John, dececed without issue, $\uparrow$ she dececed not, but the cause why that she hadde bi him none issue was this; for asmoche as the same yere that Kyng John was crowned kyng of Englond there was a deuorce made bi twene him and the saide Issabell, bicause they were founde and vndirstonde within the thirde degree of consanguinite. And the yere vpon that he was crowned king, he toke to. wife and weddid Isabell the doughtir of therle of Angolisme, vpon whome he begate his son and heire kyng Harry the thirde, and Richard his secounde son Kynge of Alemaigne, and Erle of Cornewale; and iij. doughters, that is to sey, Isabell Emperece of Rome, Elenore Countesse of Pembroke, and Johane Quene of Skotlande.

Seynt Austins
of Bristowe. Nowe to speke of the fundacion of thabbey of Seynt Austyns of Bristow, begynneng furst at Harding sonne vnto the Kynge of Denmarke, whiche dwellid in Bristowe in Baldewynne strete. And he hadde to his sonne the lorde Robert Hardyng, lorde of Berkeley, and founder of the seide Abbey of Seynt Austyns. Addyng herevnto certein covenaunts made bitwene the seide lorde Robbert Harding and Roger of Berkley, lorde of Dorsseley, folouyng here the conveyaunce of the same.

First, King Harry Beauclerk, son of William Conquerour, hadde a doughter callid Maude, that was his heir, whiche was weddid to

* This paragraph begins with fresher ink, as though the worthy chronicler had grown weary and left off for a time: then beginning afresh he found he had made an error, and hastens to correct it at $\dagger$

$\ddagger$ A part of the two following paragraphs has been printed by Seyer, Memoirs of Bristol, vol. i. pp. 465,466 . 
themperour of Alemaigne. And after the decece of the seide Emperoure King Harry sende for his doughter home into Englonde. And bicause he hadde none othir heir, he willid and desired al the barons of Englonde to do fealte vnto the seide Maude, and to admyt hir for his heir. Amongest whome the furst that swere was Stephyn Erle of Boloigne, the kynges nevewe. So it befille that after that, Geffrey Plantagenet, Erle of Angeou, weddid the seide Maude and begate on hur a son callid Harry, whiche afterwards was callid King Harry the second. And a non after the decece of King Harry the furst, the seide Erle Stephyn breke his othe, and toke on him the crowne of Englonde vnjustely agaynst his feithe and fealte that he had made to the seide Maude, vnto whome the Realme of right aught to be conserued. Whois son Harry grew duly vnto mannes state, and came into Englonde to pursewe his modirs enherytaunce and his owne right. Vnto whome Robbert the son of Hardyng assisted bi his power, and departid largely with his golde and seluer to the susteigneng of his armes. And when Harry the secounde was kyng he forgate not the grete kyndenesse of the seide Robbert, but for the same he gave him the Barony of Berkleyshernes* whiche that Roger of Berkley lorde of Dursseley hilde to fee ferme of the kyng. And the same the king toke fro him bicause he paide not his ferme, and also bicause he toke partie with king Stephin ayenst the kyng. Nevir the lees the seide Kinge Harry, at the instaunce and prayer of dyuers of his lordes, he graunted vnto the seide Roger the barony of Dursseley as his enherytaunce. How be it the seide Roger vexed and troubled in many sondry wises the seide lorde Robbert, for the whiche the seide Robbert besought the kynges gode grace to take fro him ayen the seide Barony of Berkley Hernes whiche he hadde geve him, seeng he kowde not kepe it in ease for troublyng of the seide Roger. But then the seide Kyng

* A.-S. hyrnes, what is obedient, a province or lordship. In the Saxon Chronicle, Beorclea hyrnesse is translated by Mr. Thorpe "the district of Berkeley." Rolls ed. vol. ii. p. 192. 
Harry made peace by twene Roger and Robbert, so that Roger gave his doughtir Alice to wife vnto Morice son of Robbert, and gave with hur the towne of Slymbrugge, and made double maryages bi twene their bothe children, and fynall peace bi twene them. Whiche mariages, covenaunts, and peace bitwene the seide Robbert, son of Hardyng, and Roger of Berkley, lorde of Dursseley, were made in the hows of the lorde Robert, son of Harding, at Bristowe, in presence of King Stephin and of the lorde Harry, Duke of Normandy and of Gyayne and Erle of Angeo, in presence of many othirs, lordis and knyghtes spirytuall and temporall.

Be it remembrid that Robbert the son of Harding, Knyght, the first lorde of Berkeley and founder of the Abbey of Seynt Austyns of. Bristowe, beyng bothe chanon and founder of the same, founded and newe billed the seide Monestery with all the howses of office of the same, in the yere of our Lord God $\mathbf{M}^{\circ} \mathrm{Cxl}$, and in the vijth yere of the reigne of king Stephyn. And aftir that in the yere of oure Lord God $\mathrm{m}^{\circ} \mathrm{Cxlvj}{ }^{\text {to }}$ the Bisshoppes of Worcestre, Excestre, Landaff, and Seynt Asse hallowed the seide churche of Seynt Austyns. And after that, Alurede Bisshoppe of Worcestre sende vj chanons fro Wigmore and brought to Seynt Austyns bi the seide founder, on Ester-day, the yere of oure Lord $\mathbf{M}^{\mathrm{l}} \mathrm{Cxlviij}{ }^{\circ}$. Whiche Robbert, son of Harding, hadde by his wife Eve dyuers sonnes and doughtirs. And he levid and contynewed chanon at Seynt Austyns. And Eve his wife founded the Maudeleyns of Bristowe, and levid and contynewid there Prioresse. And the seide Robbert deceded the yere of our Lorde God $\mathbf{M}^{1} \mathrm{Clxx}$, and lyeth beryed with Eve his wife in thentryng of the Quere of Seynt Austyns, bitwene the twoo stalles of thabbot and the Pryoure of the seide monastery there.*

M.lXxv.

The Busshopes see was translated fro Shirebourne vnto Salisbury W. c. ix ${ }^{\circ}$. by Bisshoppe Herman.

* End of fol. 28b. At the top of next page is the picture of W. Rufus. 
This yere was consecrated Lord John the furst Bisshoppe of $\mathbf{M}^{\circ} \mathbf{l}_{\mathbf{x x x}} \mathrm{viij}^{\circ}$. Bathe, unto whome Kynge William Rufes gave the seide Bisshop- W. ruf. sedo. riche. And the seide Bisshoppe billed the churche of Bathe.

This yere in the monthe of Nouembre was foundid thabbey of $\mathbf{M}^{\circ} \mathrm{C}^{\circ} \mathbf{x x x i x ^ { \circ }}$. Kynggeswod in the com. of Gloucestre.

Regs. S. $\mathbf{v}^{\circ}$.

This yere dececed Robbert Consul, Erle of Gloucestre, the whiche Mcxlvijo. billed the castell of Bristowe.

R. S. xiijo.

This yere in Septembre dececede lord Robert, Bishopp of Bathe, uclxvjo. which gave to the hous of Bruton* the churches of Westbury and I. ijdi xiijo. of Banwell. And the same yere in Nouember Robert, the son of William Consulle, Erle of Gloucestre, a childe, dececed at Keerdief and brought and buried at Keynesham, for whos soule the fader and modre foundid thabbey of Keynesham.

This same yere $\uparrow$ was the church of Keynsham founded bi Wil- Mclxxjo. liam Erle of Gloucestre and bi the ladi Hauwisse his wif, and bi H. ijdi xviijo. the Lord Roger, brother to the said Erle, than beeng Bishoppe of Worcestre, in presence of pe Bishops of Bathe and of Excestre.

This yere Sauaricus was made Bishopp of Bathe, whiche had the Mclxxxxvj. same yere of King Richard is gefte the patronage of thabby of R. primi viijo. Glastonbury to thencrece of his bishopriche, and so thei were combyned the churches of Bathe and of Glastonbury, whiche combynacion Celestinus the Pope confermed.

This yere Jocelyn was made Bishop of Bathe, which halowid the Mccrij. churche of Bathe the yere of our Lord MCCxxxix. And he new made Joh'is ix. the cathedrall churche of Welles and purchased many possessions to the same churche, and gretely encreced the noumbre of Chanons and Vicaries of the same church.

* Under the date 1142 is the entry "In August was foundid the religeous of reguler Chanons of the churche of Brewton."

$\uparrow$ See the last extract. 
[At end of history of John's reign is the following:]

Fo. $58 a$.

Yet is it requisite and fittyng vnto thenhabitaunts of the Towne of Bristowe somwhate more to speke and wryte of this Kynge John, for as moche as this worshipfull Towne of Bristowe ys so largely and frely fraunchised, and the burgeises of the same endewed with manyfolde fredoms, libertees, vsages, and free auncient custumes innumerable, tyme oute of mynde graunted by dyuers kinges of Fnglond, passing any mans witte al to remember or expresse, as in the beginnyng of this boke it hath ben shewed. Wherfore this kinge John, whome God assoille, amongest others ar that he was kinge, beyng Erle of Morteyn and Lorde of Bristowe, bi just title and ryght of Dame Issabell then his wiff as ryght heire of the Castell and Towne of Bristowe, graunted vnto the burgeisis of the same dyuers fredoms and libertees; that is to sey:-Furst that no burgeis of Bristowe shall not emplede a nother burgeis oute of the Towne of Bristowe for no maner cause, but hit be for londes and tenementes lyenge and beeng withoute the lybertees and procincte of the saide Towne. Also that they shall be quyte of murther within the saide Towne. Also that no burgeis shall not wage no bataille in lasse then he be appelyd of the murther of a foreyne man. And that no burgeis ne enhabitaunt of Bristowe shall receiue none oste into his howse * by lyverance of the kynges Marchall ayenst the wille of the burgeis. And that thei shall be quyte of tolle, lastage, passage, and of al other custumes through all his londe and power. And who so trowble or interipte them to pay $x$ li. And no burgeis to be amercyed ne pay no mercyment but after the lawe of the hundred, and that the hundred be hold ones euery woke. And that none estraunge marchaunt by ne sille within the towne with none other straunger, and that none straunge marchant abide with his marchaundyse in the saide Towne above $x l$ dayes. Ne no straunger to retayle within the saide Towne. And that they hold al theire

* "Nemo capiat hospitium infra muros" in the original Latin of John's Charter. Seyer's Charters of Bristol, p. 6. 
landes and tenements within the procincte of the saide Towne in Free burgage, by reason of the langable. And lycens for to bilde all the voyde places within the sayde procincte, and vpon the ryueres sydes of the same Towne at their pleasure. And also graunted theim lycens to chese their Crowners with in theym self." Thes freedoms with many others Kynge John graunted to the burgeisis of Bristowe full liberally, as by his chartrez of the same- more playner it apperith. Whiche fredoms and libertees, with many and dyuers others therto addid by his noble son, that Prynce of blessid memorie Kyng Harry the third, haue ben ful largely and graciously confermed, and after hym by his son that blessed and vyctoryous Prynce Edward the furst. And so after by al theyre successours ful largely encresed and confermed in fraunchesyng of this noble Towne. And nowe shal y procede on the thirde Pryncipalle of this boke.

\section{Tercium |arincipale.†}

[In the Third Part Ricart carries on the yearly chronicle, but heads each year with the names of the mayor and provosts, stewards, bailiffs, or sheriffs, as the case may be, beginning, with the 1st Henry III. The narration of "Actes done" is but slight : in the earlier years it has been mainly drawn from Mathew of Westminster. There are many pages where nothing beyond the names of the officers appears, each page being arranged with the headings for two years, but time or opportunity having failed the compiler to fill them in. Coming near the writer's own time, however, and later, many notices of value to local history are scattered through the pages, along with the general history. It is remarkable that one of these is related at length by Fabyan, who was a contemporary, though it is little, if at all, mentioned in other chronicles.

The Part occupies more than 150 leaves (beginning at fol. 59), but not consecutively ; it is interrupted by Parts IV. and V. in two places (see Introduction). Ricart's hand, which is firm and clear, appears as far as the end of Henry VII. (fol.

* John's charter, which has no date, but was probably granted between 1183 and 1190, was confirmed in $36 \mathrm{Hen}$. III. (1252), and again in $28 \mathrm{Edw}$. I. (1300). The power to choose their own coroner was first declared by the charter of $40 \mathrm{Hen}$. III. (See after, Quintum Principale.)

$\dagger$ There is no title in the original to this Part.

CAMD. SOC. 
135, 136); after that a small close hand continues. In one or two places a more modern hand has inserted a short quotation from Stow.

In printing this part it has been necessary, as before, to make a selection, but the original form and chronological order have been preserved as far as possible. The reader will therefore find-The complete list of mayors and officers up to A.D. 1479 (see Introduction) - the chronicle for most of this portion has been omitted, as containing nothing but what is to be found elsewhere ; the entire chronicle from 1422 to 1550 , with the names of mayors only; from 1550 to 1698 , the portions of most interest,-nothing being omitted but a few unimportant notices of well-known events.

In the MS. the dates of the years of our Lord, and of the reign; are put in the margin, to every year throughout (in Roman figures up till 1680), and the names of the officers are arranged thus :

\section{Adam le Page, Maior. \\ Stephanus Stanekyn, \\ Reginaldus Hazarde, $\}$ prepositi.}

For convenience the years A.D. only are printed where the names alone occur, the regnal years being retained with the record of events, in order towards fixing the date, and for comparison with other similar chronicles. For convenience also the numerals have been altered into arabics.]

Fo. $59 a$.

And nowe the thirde Principall of this boke folouyng shal shewe fro the tyme and decece of this saide kyng John, and fro the begynnyng of the reigne of his son that noble Prince kyng Harry the thirde, the names of al the Maires, Provostis, Shirefs, and Baillifs that have been and contynewed tyme out of mynde in this worshipfull Towne. And somme of the Actes that haue be done in euery of theire yeres, in perpetuell remembraunce to thenhabitaunts of the same.

Whiche kynge Harry the thirde was crowned at Gloucestre in the day and feste of Symon and Jude Apostils in the yere of oure Lorde $\mathrm{M}^{1} \mathrm{CCxvj}$, and in the $\mathrm{ix}^{\text {th }}$ yere of his age. And forthewith aftir his coronacioun there he came to Bristowe and hilde there his grete Counseile in maner of a Parlement.*

* The picture of Henry III. is placed here, on fo. 596 . 
A.D.

Maiores.

1217. Adam le Page.

1218. Martinus Vndiryate.

1219. Johannes at Hulle.

1220. Robertus Holburst.

1221. Rogerus de Stanes.

1222. Walterus Mombray.

1223. Johannes de Berdewyke.
Prepositi.

Stephanus Stanekyn.

Reginaldus Hazarde.

Ricardus Martyn.

Hugo Upwell.

Ricardus le Palmer.

Johannes Snowe.

Johannes Oldeham.

Henricus Vynepeny.

Petrus le Goldesmyth.

Robertus de Monmouth.

Johannes de Romney.

Philippus le Cok.

Robertus de Westone.

Willelmus Daxe.
Fo. 60 .

H. tercii primo.

This same yere a rose a grete persecucion in the Citee of London H. tercii vijo. by Walter Bokerellys appechement, so that Constantyne the son of Arnulphe, the morowe aftir our lady day Assumpcyon, was y-drawen and $y$-hanged. Also this same yere the kynge was in purpos to have y-caste down the wallis of London.*

A.D Maiores.

1224. Jacobus de Rowborowe.

1225. Walterus de Wyntone.

1226. Hugo de Fayreforde.

1227. Johannes de Mersshefielde.

1228. Henricus le Long.

1229. Nicolaus Heyhome.

1230. Johannes Bruselaunce.

1231. Henricus de Berewyke.
Prepositi.

Thomas le Spycer.

Walterus de Vbbeley.

Robertus Martyne.

Johannes Methelam.

Ricardus de Bury.

Johannes de Bradewas.

Willelmus Colpek.

Nicolaus Coker.

Alexandre Rope.

Henricus de Camene.

Willelmus Tyarde.

Ricardus Bryan.

Nicolaus de Portbury.

Willelmus le Hayle.

Radulphus Atteslupe.

Walterus le Rede.

* This account seems to have been taken from the same source as that used by Fabyan, as it mentions Walter Bokerell and the King's intention to throw down the walls, points which other writers do not allude to. 
A.D. Malores.

1232. Elyas Spryngham.

1233. Walterus le Fraunceis.
Prepositi.

Johannes de Keredief. Johannes at Walle. Henricus le Walleys. Thomas de Pedyrtone.

H. tercii xvijo. This yere dececid Richard of Keynesham, aftir whome succedid John of Swyneshede.

A.D. Malores.

1234. Ricardus Aylard.

1235. Jurdanus Browne.

1236. Jacobus le Warre.

1237. Ricardus Horston.

1238. Philippus de Powlet.

1239. Ricardus Forstall.

1240. Ricardus Aylard.
Prepositi.

Gilbertus le Plommer.

Thomas le Chalner.

Thomas Vpdiche.

Johannes Ergleys.

Willelnuss Clerk.

Johannes le Belyetere.

Willelmus Golde.

Ricardus de Bury.

Thomas Ayleward.

Rogerus Cantok.

David le Wight.

Ricardus de Leymstre.

Willelmus Tonarde.

Johannes Northfolke.
H. tercii xxiiijo.

This yere was the Trenche $y$-made and y-caste of the ryvere, fro the Gybbe Tailloure* vnto the key, by the maanovre of alle the Cominalte, as wele of Redcliff warde as of the Towne of Bristowe. And the same tyme thenhabitaunt3 of Redecliff were combyned and corporatid with the Town of Bristowe. And as for the grounde of Seynt Austyn's side of the forseid ryver hit was yeve and grauntid to the Cominaltee of the seid Towne by Sir William a Bradstone then Abbot of Seynt Austyns for certeyn money therfore to hym paide by the seide Cominaltee. As appereth by olde writyng therof made bitwene the forseid Maire and Cominaltee and the seid Abbot and Covent. $†$

A.D. Maiores.

1241. Thomas de Weston.
Prepositi.

Ricardus Osmonde. Johannes de Callande.

* See this place mentioned after, under date 1574 .

$\uparrow$ The covenant made between the two parties is given from the original by Seyer (Mem. Bristol, ii. p. 19 ; it is contained in the Great Red Book, fo. 1), who 
A.D. Maiores.

1242. Robertus le Bele.

1243. Willelmus Clerk.

1244. Willelmus Spakstone.

1245. Radulphus Monjoy.
Prepositi.

Willelmus de Chiltone.

Henricus le Cheynere.

Willelmus de Bellomonte.

Robertus Kylmanan.

Willelmus de Leigh.

Robertus Parmenter.

Paulus Cute.

Rogerus Snake.

has a long account of this important undertaking of the early engineers. The " trench" then made runs along the place now known as the Broad Quay, continued by the Narrow Quay : the old course of the river Frome was filled up, and its waters made to fall into the Avon lower down near the present bridge at Prince's Street. At the present time the name of "Floating Harbour" is given to what is really the old course of the Avon ; what is now called the "river Avon," near the City, is the modern cut, finished in 1809.

There was a close connection between the men of Bristol and their neighbours of the Marsh, afterwards called Redcliff. This is shown in several charters, of which one was from Henry II., and another from Robert son of Harding (who died in 1170; see before, p. 22). Transcripts of these charters are in the Little Red Book, fo. $12 b$, which must be where Barrett found them, though, as Seyer complains, he does not give either the originals or his authority. They are as follow:-

"Henricus Rex Angliæ, Dux Normaniæ et Aquitanniæ, Comes Andegaviæ, omnibus baronibus justiciariis vicecomitibus et omnibus ministris suis Angliæ et Walliæ, salutem. Concedo quod homines mei qui manent in feodo meo in Marisco juxta pontem de Bristollia habeant suas rectas consuetudines et libertates et quietancias per totam Angliam et Walliam, sicut mei burgenses, et nominatim in Bristollia et per totam terram comitis Glouc', sicut carta mea testatur, et prohibito ne super hoc aliquis eis faciat aliquam injuriam vel contumeliam."

". [Robert] Filius Hardingus omnibus amicis suis et hominibus præsentibus et futuris salutem. Notum sit vobis, quod ego concessi et confirmavi quod homines mei qui manent in feodo meo in marisco juxta pontem de Bristollia, habeant suas consuetudines et libertates et quietancias quas homines de Bristollia habent, sicut rex dominus noster eis concessit et carta sua confirmavit; et volo quod ita integras et plenarias eis maneant tempore meo et heredum meorum omnium. Teste Ricardo Abbate Sancti Augustini," \&c.

The "men who dwell in the marsh" of these charters are spoken of as "men of Redclive" in a charter granted by Maurice the son of Robert. Maurice's charter, together with a mandamus of $24 \mathrm{Hen}$. III. to the men of Redcliff to join in the expense of making the trench, and the charter of 31 Hen. III. A.D. 1247, are all contained on fo. 12 of the Little Red Book. The last of these drew the connection still closer, if they were not already incorporated with Bristol, as stated in the text. (See Seyer's Mem. Bristol, ii. pp. 30, 31, 45; Charters of Bristol, No. v.) 
A.D. Maiores.

1246. Elyas de Axbridge.

1247. Reginaldus de Penes.

1248. Galfridus le White.

1249. Johannes Adryan.

1250. Rogerus de Bury.

1251. Elyas Long.

1252. Thomas le Rous.

1253. Reynoldus de Wight.

1254. Henricus Adryan.

1255. Adam de Berkham.

1256. Robertus de Kylmaynan.

1257. Rogerus de Berkham.

1258. Rogerus de Stokes.

1259. Clemens de Romeney.

1260. Willelmus de Gloucestre.

1261. Johannes de Lyme.

1262. Robertus de Kylmaynan.

1263. Adam de Berkham.

1264. Thomas le Rous.

1265. Henricus Adryan.

1266. Stephanus Ormestone.

1267. Thomas Selby.
Prepositi.

Johannes de Sancta Barba. Ricardus de Tylloy.

Johannes de Westone. Walterus de Berkham.

Walterus Tropyn. Willelmus Snake. Walterus Talmage. Henricus Farneham. Thomas de Norwodde. Johannes Cornehill.

Robertus de Bellemonte. Gilbertus de Marlebrege. Johannes at Knolle. Robertus at Wodde. Radulphus Oldeham. Willelmus Hazildene. Hugo Mychell. Willelmus Sevare. Robertus Shyrley. Willelmus Frebody. Johannes Berwyk. Rogerus Golde. Hugo Mychell. Willelmus de Berwyk. Thomas Eldesham. Robertus Pykerage. Rogerus Pepyr. Thomas Wynfyelde. Johannes Hertishorne. Robertus Horneby. Radulphus le Brydde. Stephanus le Cokke. Thomas Trenwyth. Ricardus de Russhton. Thomas de Hanyngfield. Galfridus Vssher. Henricus de Puxton. Robertus Tren'worth. Thomas Caperon. Willelmus Chadborne. Radulphus Bawdewyne. Johannes Exhulle.

Senescalles.

Reginaldus Ricard. Johannes Peperton. 
A.D.

Maiores.

1268. Symon Clerk.

1269. Robertus Mauncelle.

1270. Rogerus Fissher.

1271. Radulphus Paldene.

1272. Johannes Wissy.

1273. Ricardus de Wellis.

1274. Petrus de Keynesham.

1275. Thomas de Hamelesden.

1276. Gerardus le Fraunces.

1277. Symon de Bardeney.

1278. Johannes Lydeyarde.

1279. 'Rogerus le Tavyrnere.

1280. Petrus de Romeney.

1281. Willielmns Beauflure.

1282. Nicolaus Horncastell.

1283. Thomas Cokere.

1284. Petrus de Romeney.

1285. Ricardus Mangottesfield.

1286. Ricardus Mangottesfielde.

1287. Johannes le Warre.

1288. Rogerus de Graftone.

1289. Ricardus le Draper.
Senescalles.

Johannes Wissy.

Hugo Mychelle.

Johannes Legat.

Petrus Martre.

Symon Adryan.

Rogerus Draper.

Ricardus Austyne.

Thomas Haseldene.

Rogerus de Canto.

Willelmus Berwyk.

Robertus Snoward.

Symon de Wedmore.

Johannes Salekene.

Radulphus de Axe.

E. primi primo.

Symon Adryan.

Willelmus de Maryna.

Johannes de Portishened.

Robertus Lancastle.

Robertus de Kyngeswod.

Reginaldus le Eu.

Robertus Trewelove.

Willelmus le Skryvene.

Johannes Bryan.

Nicolaus at Oke.

Johannes Hodde.

Thomas Colston.

Johannes de Kerdyef.

Robertus de Wylmersshe.

Willelmus.de Wedmore.

Robertus Goldyng.

Ricardus atte $\mathrm{Ok}$.

Guillemyne de Boys.

Ricardus Tombrelle.

Willelmus Wychewelle.

Henricus Horncastelle.

Galfridus Snelle.

Thomas de Westone.

Johannes Tony.

Willelmus Hawdene.

Thomas Prestlay.

Thomas Roystone.

Johannes Benyngtone.

Johannes de Cheddre.

Johannes le Longe. 
A.D.

Maiores.

1290. Ricardus Mangottesfielde.

1291. Rogerus Turtle.

1292. Thomas de Tilley.

1293. Walterus le Fraunces.

1294. Symon de Burton.
Senescalles.

Symon de Burtone.

Willelmus de Randolf.

Johannes Fraunces. Hugo de Langbrige.

Walterus Glenne. Symon Rycrofte.

Galfridus a Goddeshalf. Johannes le Tavirnere.

Johannes Snowe. Johannes de Cheddre.

E. primi xxij॰. This yere the abovesayd Simon Burton began to build Redclyf churche.*

A.D. Maiores.

1295. Symon de Burton.

1296. Symon de Burton.

1297. Willelmus Randalf.

1298. Johannes Snowe.

1299. Ricardus de Mangottisfield.

1300. Rogerus Tortle.

1301. Thomas de Tylley.

1302. Walterus Adryan.

1303. Thomas de la Grave.

1304. Symon de Burton.

1305. Symon de Burton.
Senescalles.

Robertus de Oterey.

Nicolaus de Roborough.

Robertus de Oterey.

Willelmus de Roborowe:

Thomas Vpdyche.

Robertus Hobbusshe.

Johannes le Lung.

Adam Welishot.

Galfridus a Goddeshalf.

Willelmus le Maryner.

Johannes Fraunces.

Hugo de Langbrige.

Ricardus Collepyt.

Willelmus de Glastunbury.

Robertus Bostok.

Johannes Harssalle.

Johannes Tyke.

Rogerus Beufloure.

Willelmus Vpdyche.

Robertus Horehurst.

Robertus de Otrey.

Nicolaus de Rowborowe.

* This note is not in Ricart's hand, but in one of much later date, and appears to have been added in about the beginning or middle of the seventeenth century. The same hand wrote the note under the date 1376 , after. 
A.D. Maiores.

1306. Willelmus Randalf.

1307. Johannes Snowe.

1308. Johannes le Tavyrner.

1309. Johannes le Tavyrnere.

1310. Willelmus Randalf.

1311. Johannes du Seler.

1312. Willelmus Hore.

1313. Johannes le Tavyrner.

1314. Reginaldus de Panys.

1315. Willelmus Randolf.

1316. Robertus Passoure.

1317. Rogerus Tortle.

1318. Rogerus Tortle.

1319. Ricardus de Tilley.

1320. Ricardus de Tilley.

1321. Ricardus de Tilley.

1322. Ricardus de Tilley.

1323. Willelmus de Axe.

1324. Johannes de Keynesham.

1325. Johannes de Rumsey.

1326. Johannes de Rumney.

1327. Rogerus Turtle.

CAMI). SOC.
Senescalles.

Johannes de Cheddre.

Johannes le Long.

Nicolaus de Burton.

Thomas de Berwyk.

Willelmus de Olyef.

Gilbardus Pokerell.

Robertus de Otrey.

Adam Welishot.

Johannes Romney.

Walterus Tropyn.

Ballivi.

Thomas le Spysour.

Robertus Randalf.

Johannes Beaufloure.

Thomas le' Spicer.

Laurencius de Cary.

Ricardus le White.

Radulphus Wynemone.

Johannes le Honte.

Robertus le Holburst.

Johannes Walishot.

Ricardus Colpek.

Henricus Vynypeny.

Johannes Fraunces.

Hugo de Langbrige.

Thomas le Spicer.

Johannes de Rumsey.

Ricardus de Paynes.

Ricardus le White Iremonger.

Willelmus Hanyngfield.

Hugo le Prowte.

Gilbertus Puckerell.

Clemens Turtle.

Gilbertus Puckerell.

Clemens Turtle.

Robertus de Lutelbury.

Galfridus de Wroxall.

Everardus le Fraunces.

Stephanus le Spycer.

Gilbertus Puckerell.

Henricus de Eston.

Jobannes Fraunces.

Walterus Prentise.

Robertus Gyen.

Euerardus Fraunces.
E. secundi primo. 
A.D.

Maiores.

1328. Rogerus Turtle.

1329. Hugo Langebrige.

1330. Johannes Fraunces.

1331. Johannes de Axbrige.

1332. Rogerus Turtle.

1333. Rogerus Turtle.

1334. Enerardus le Fraunces.

1335. Rogerus Turtle.

1336. Hngo de Langbrige.

1337. Rogerus Turtle.

1338. Euerardus le Fraunces.

1339. Stephanus le Spycer.

1340. Euerardus le Fraunces.

1341. Rogerus Turtle.

1342. Rogerus Turtle.

1343. Robertus de Wryngtone.

1344. Stephanus le Spycer.

1345. Stephanus le Spycer.

1346. Robertus Gyen.

1347. Robertus Gyen.

1348. Robertus Wryngtone.

1349. Johannes le Spycer.

1350. Robertus Gyen.
Ballivi.

Robertus Gyen.

Euerardus Fraunces.

Joceus le Rayny.

Nicolaus le Freo.

Johannes at Wall.

Henricus de Framptone.

Rogerus Pluste.

Henricus Babcary.

Stephanus le Spycer.

Henricus Babcary.

Stephanus le Spycer.

Henricus Babcary.

Joceus le Rayny.

Thomas Torpen.

Jacobus de Rayny.

Petrus Testyne.

Stephanus le Spycer.

Thomas Torpen.

Ricardus de Calne.

Walterus de Pelevile.

Thomas Tilley.

Johannes de Lexam.

Robertus de Wryngtone.

Johannes le Spycer.

Thomas Torpyn.

Johannes de Cobyntone.

Jacobus Tylley.

Thomas Blanket.

Thomas Turpyn.

Thomas Blanket.

Johannes Curteys.

Willelmus Hanny.

Willelmus Haynes.

Thomas Albone.

Willelmus Haynes.

Thomas Albone.

Johannes Nele.

Jacobus Tilley.

Robertus Godemer.

Willelmus Hanny.

Rogero Beauner. Walterus Wenelake.

Johannes Cobyndon. Robertus Prentise.

Edmundus Blanket. Johannes Castelcare. 
A.D. Maiores.

1351. Johannes Wycombe.

1352. Johannes Spycer.

1353. Johannes Cobyntone.

1354. Ricardus le Spycer.

1355. Ricardus le Spycer.

1356. Thomas Babcare.

1357. Reynoldus Frensshe.

1358. Walterus Framptone.

1359. Reynaldus Frensshe.

1360. Thomas Babcare.

1361. Robertus Cheddre.

1362. Ricardus Brandon.

1363. Robertus Cheddre.

1364. Walterus Derby.

1365. Johannes Stoke.

1366. Walterus Frampton.

1367. Johannes Stokes.

1368. Walterus Derby.

1369. Johannes Bathe.

1370. Elys Spelly.

1371. Johannes Bathe.

1372. Ricardus Spycer.
Ballivi.

Reynaldus le Frensshe.

Willelmus Combe.

Walterus Derby.

Robertus Cheddre.

Johannes Castelcare.

Thomas de Coventre.

Robertus at Welle.

Johannes Stoke.

Johannes Stoke.

Ricardus de Dene.

Ricardus Inhyng.

Johannes Cobynton.

Walterus Derby.

Thomas Inhyng.

Ricardus Brandone.

Galfridus Benfloure,

Johannes Soor.

Henricus Vyell.

Walterus Derby.

Johannes Stoke.

Elyas Spelle.

Willelmus Somerwell.

Walterus Derby.

Willelmus Canynges.

Elys Spelle.

Henricus Wiliston.

Henricus Wylliston.

Willelmus Wodderove.

Willelmus Hayle.

Johannes Bate.

Johannes Sloo.

Henricus Williston.

Willelmus Somerwell.

Johannes Kene.

Willelmus Dagon.

Johannes Blount.

Johannes Blount.

Johannes Vyell.

Willelmus Canynges.

Johannes Vyell.

Thomas Beupeny.

Henricus Vyell.

Johannes Inhyng.

Johannes Preston. 
A.D. Maiores. Vicecomes. Ballivi.
1373.* Willelmns Canynges. Johannes Vyell.
1374. Willelmus Canynges. Johannes Vyell.
1375. Walterus Framptone. Thomas Benpeny.
Thomas Sampson. Walterus Stodley. Thomas Sampson. Walterus Stodley. [blank.]

E. tercij $1^{\circ}$.

1376. Willelmus Canynges. Henricus Vyell. [blank.]

This yere $\dagger$ William Canynges builded the bodye of Redclyf church, from the crosse Iles downewardes. And so $y^{\mathrm{e}}$ church was ffynished as it is nowe.

1377. Walterus Derby.

R. secundi primo.
1378. Thomas Benpeny.

1379. Elyas Spelly.

1380. Johannes Stokys.

1381. Walterus Derby.

1382. Willelmus Canynges.

1383. Elyas Spelly.

1384. Thomas Beaupeny.

1385. Walterus Derby.

1386. Willelmus Canynges.

1387. Thomas Knappe.

1388. Willelmus Somerwell.

1389. Johannes Vyell.

1390. Willelmus Canynges.
Willelmus Sómerwell.

Walterus Studley.

Willelmus Coombe.

Thomas Knappe.

Willelmus Somerwell.

Johannes Candavir.

Johannes Canynges.

Robert Candavir.

Thomas Sampsone.

Johannes Somervell.

Petrus Baroghe.

Willelmus Froome.

Willelmus Wodroof.

Johannes Barstable.
Willelmns Combe. Thomas Knappe. Thomas Sampson. Walterus Tyddeley.f Willelmus Erlyngham. Johannes Stanes.

Johannes Stanes. Johannes Barstable.

Robertus Candavir. Willelmus Canynges.

Walterus Saymour. Johannes Pristone.

Johannes Stanes. Willelmus Warmystre. Johannes Somervell. Peter Baroghe.

Johannes Yonge. Willelmus Draper. Rogerus Touker. Johannes Tryt.§ Willelmas Frome. Thomas at Hay. Thomas Colston. Willelmus Snell. Thomas at Hay. Johannes Stephins. Johannes Banbury. Johannes Hauering.

* The picture of the first Sheriff is inserted after this year.

$\dagger$ See before, under 1294, note.

$\ddagger$ In the "Little Red Book" this name is written Tydstyll.

$\S$ Brytt in "Little Red Book." 
A.D.

Maiores.

1391. Elyas Spelly.

1392. Thomas Knappe.

1393. Johannes Canynges.

1394. Johannes Somerwell.

1395. Willelmus Frome.

1396. John Barstaple.

1397. Thomas Knappe.

1398. Johannes Banbury.

1399. Johannes Canynges.

1400. Thomas Knappe.

1401. Willelmus Frome.

1402. Johannes Barstaple.

1403. Johannes Stephins.

1404. Thomas Knappe.

1405. Robertus Dudbroke.

1406. Johannes Barstaple.

1407. Johannes Droyes.

1408. Thomas Blount.

1409. Johannes Fissher.

1410. Johannes Droys.

1411. Johannes Sely.

1412. Thomas Yonge.

1413. Johannes Cleve.
Vicecomes.

Ballivi.

Thomas at Hay.

Johannes Banbury.

Walterus Saymoure.

Johannes Hauering.

Johannes Stephins.

Rogerus Towker.

Willelmus Warmynstre.

Johannes Pryston.

Robertus Baxster.

Thomas Blont.

Robertus Dudbroke.

Thomas Nortone.

Johannes Sely.

Thomas Gloucestre.

Johannes Droyes.

Marcus William.

Johannes Fissher.

Thomas Yonge.

Johannes Cleve.

Jacobus Cokkys.

Nicolaus Excestre.

Johannes Spyne.

Johannes Sharpe.
Robertus Dudbroke. Johannes Selwodde. Johannes Burtone. Ricardus Hanteford. Thomas Norton. Ricardus Brokworth. Willelmus Solers. Thomas Blont. Johannes Prystone. Johannes Castell.

Robertus Dndbroke. Johannes Castell.

Robertus Brokworthe. Johannes Hardewyk. Willelmus Draper. Henry Bokerell. Johannes Lemman. Johannes Sodbury. Thomas Gloucestre. R. secundi Galfridus Barboure. Marcus William. Johannes Sely. Ricardus Panys. Simon Algode. Thomas Yonge. Nicolaus Excestre. Johannes Droyes. Adamus Inhyng. . Robertus Russelle. Gilbertus Joce. Johannes Cleve. Johannes Newtone. Jacobus Cokkys. David Dudbroke. Johannes Spyne. Robertus Barstable. Johannes Sharpe. Johannes Leycestre. Johannes Sutton. Willelmus Benley. Robertus Colvelde. Walterus Parle. Willelmus Stephins. David Ruddok. Thomas Hendy. Willelmus Baret. xxiijo et $\mathrm{H}$.

iiijts primo. 
A.D. Maiores.

H. $v^{\text {ti }}$ primo. 1414. Thomas Nortone.

1415. Johannes Droyes.

1416. Johannes Sharpe.

1417. Thomas Blount.

1418. Robertus Russell.

1419. Johannes Newtone.

1420. Jacobus Cokkys.

1421. Thomas Yong.

H. $v^{t i} i x^{0}$.
Vicecomes.

Johannes Newton.

Robertus Russell.

Willelmus Beneley.

David Dudbroke.

Johannes Leycestre.

Johannes Burtone.

David Ruddok.

Rogerus Lyvedon.

Nicolaus Bagod.
Ballivi.

Willelmus Westirley. Walterus Milton, sen. Johannes Draper. Johannes Miltone. Nicolaus Baggod. Johannes Shipwarde.

Johannes Burton. Nicolaus Devenyssh. Rogerus Leviedone. Walterus Miltone. Thomas Halwey. Johannes Langley. Henricus Gildeney. Thomas Fisshe. Ricardus Trenolde. Johannes Coton. Ricardus Arves. Edmundus Browne.

This same yere the xiijth day of August the newe wethir cokke was sette vpon Seynt Powles stepill in London. And this same yere the last day of August, the noble kyng Harry the fifte aftir the Conquest, at Boys Seint Vyncent beside Paryes in Fraunce, endid his lyfe, in the begynneng of the $x^{\text {th }}$ yere of his reigne. Whois bones the vij day of Nouembre then folouyng were worthely enterrid at Westmyster, as yet apperyth. And this yere the forsaide Shiref dececid and John Mylton accomplisshid the yere.

H. vj" primo.

1423. Marcus William.

1424. Johannes Burton.

1425. Johannes Leycestre.

1426. Johannes Cleve.

1427. Robertus Russell.

1428. Johannes Newtone.

1429. Rogerus Levedone.
Ricardus Trenolde.

Thomas Halwey.

Thomas Erle.

Robertus Colvelde.

Nicolaus Devenysshe.

Johannes Sharpe.

Henricus Gyldeney.
Thomas Erle. Johannes Peers. Johannes Heethe. Ricardus Elysaunder. Johannes Sharpe. Johannes Hoke. Walterus Powere. Johannes Snethe.

Clemens Bagod. Hugo Wethiforde. Andreas Parle. Johannes Eyre. Johannes Talbot. Johannes Troyte. 
A.D. Maiores.

1430. Johannes Burtone.

1431. Johannes Leycestre.

1432. Ricardus Trenolde.

1433. Johannes Sharpe. vicecomes.

Johannes Shipwarde.

Hugo Wethrforde.

Clemens Bagod.

Ricardus Arveys.
Ballivi.

Ricardus Foster. Johannes Alburton. Willelmus Dunstar. Johannes Papenham. Johannes Spycer. Nicolaus Freme. Thomas Noreys. Willelmus Canynges.

This yere was the grete Clipse $\mathrm{y}$-seen in Bristowe.

1434. Johannes Fissher.

1435. Thomas Halleway.

1436. Johannes Miltone.

1437. Ricardus Forster.

1438. Clemens Bagod.*

1439. Hugo Wethrforde.

1440. Johannes Sharpe.

1441. Nicolaus Freme.

1442. Willelmus Canynges.

1443. Clemens Bagod.

1444. Johannes Stanley.

1445. Johannes Shipwarde.

1446. Nicolaus Hille.

1447. Ricardus Forster.
Ricardus Forster.

Thomas Fissher.

Johannes Spycer.

Walterus Powere.

Nicolaus Freme.

Willelmus Canynges.

Ricardus Roper.

Johannes Stanley.

Johannes Shipward.

Nicolaus Hille.

Willelmus Codir.

Johannes Foorde.

Johannes Boltone.

Johannes Troyte.
Johannes Englisshe. Thomas Markes. Ricardus Roper. Johannes Stanley.

Nicolaus Hille. Willelmus Clynche. Willelmus Codir. Johannes Forde. Thomas Hore. Thomas Balle. Thomas Mede. Johannes Gosselyne. Willelmus Pavy. Johannes Shipwarde. Johannes Wethrforde. Willelmus Howelle.

Nicolans Stone. Robertus Sturmy. Ricardus Hatter. Ricardus Haddone. Willelmus Skyrmot. WillelmusPownesham. Phillipus Mede. Thomas Rogers. Ricardus Marshall. Ricardus Bailly. Willelmus Damme. Willelmus Talbot.
H. $\mathrm{vj}^{\mathrm{ti}} \mathrm{xxv}^{\mathrm{o}}$.

This yere Kyng Harry the vj ${ }^{\text {tus }}$ came furst vnto Bristowe, and was there worshipfully receyued.

* T'homas Bagod in the "Little.Red"Book." 
A.D. Maiores. Vicecomes. Ballivi.

H. vjti $\mathrm{xxvj}^{\circ}$. 1448. Ricardus Forster. Thomas Balle. Willelmus Rolffe.

Johannes Wykam.

This yere the Kyng came ayen to Bristowe, and this yere the Baillifs of Bristowe brought into the comen cofers $\mathrm{C}$ marcs sterlinges to the vse of the Chambre, a yenst theyre wylle, for they were cohartyd thereto by the counseile; whiche money as it was saide was stole fro a vicory of Alhallowen.

H. vjti xxvijo. , 1449. Johannes Burton.

Willelmus Pavy.

Johannes Estmonde. Johannes Benet.

This yere the Bakke* of Bristowe was repayred, al the egis of it and of the slyppes, with free stone.
H. vjti xxviijo.
1450. Willelmus Canynges.
Thomas Hore.
Ricardus Alburton.
H. $\mathrm{vj}^{\mathrm{ji}} \mathrm{xxix}^{\mathbf{0}}$.
1451. Johannes Burton.
Robertus Sturmy. Willelmus Spencer.
H. $\mathrm{vj}^{\mathrm{ti}} \mathrm{xxx}^{\mathrm{o}}$. 1452. Johannes Stanley.
Ricardus Hatter.
H. jj $^{\text {ti }} \times \dot{x x j}^{\circ}$. 1453. Willelmus Codir.
Thomas Mede.
Johannes Sharpe jun. Willelmus Dillyng.
Robertus Jakys. Johannes Hoopere. Thomas Asshe. Willelmus Raynes.

This yere in the begynneng of May William Pole, Duke of Suffolke, was slayne in the Nicholas of Toure, a lytill besides Sandewyche. $\uparrow$
H. $\mathbf{v j}^{\mathrm{t}} \mathrm{xxxijo}$.
1454. Robertus Sturmy.
Willelmus Howell.
Thomas Kempson.
Nicolans Long.

* The Back is a river-side street extending along the Avon southwards from Bristol Bridge. Back is a name of several streets in Bristol, as Augustine's Back, Redcliff Back, St. James's Back, Hollow Back (see under date 1484), and appears to mean the street at the back of the water, not to be the word beck, as has been suggested, which would be applied to the water itself, not to the street.

+ The pursuit of the Duke of Suffolk by the vessel Nicholas of the Tower, and his murder, were recent enough to have been within Ricart's own ken, yet he misplaces the date; 1450 , not 1453, was the year in which they took place. See Stowe's Annals (Howes), p. 388; Fenn's Paston Letters, vol. i. pp. 39, 40. 
A.D.

Maiores.

1455. Ricardus Hatter.
Vicecomes.

Philippus Mede.
Ballivi.

Johannes Cogan. Willelmus Hotton.

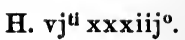

This yere the Thorsday byfore Whitsonday, that is to say the xxj day of May, kyng Harry and the Duke of Yorke mette at Seynt Albons violently, where there was sleyne Edmonde Duke of Somerset and the Erle of Northumburt and the lorde Clifforde: and fro thens forthe the Duke of Yorke toke rewle of Kynge Harry.

1456. Johannes Shipwarde. Thomas Rogers.
Johannes Bagod. Robertus Bolton.
H. $\mathrm{jj}^{t \mathrm{x}} \mathrm{xx \textrm {iiij }}$.

This yere certein Iressh burgeisez of Bristowe began a sewte a yenst the Maire and the Counseile byfore my lorde Chaunceler, with subpenas and prevy sealis, of the whiche Iressh men one Harry May was vaunt parloure and chief labourer; for the whiche he and al his fellowes were discomenyd of theyre freedom, til they bought it ayen with the blodde of theyre purses, and with weping Ien, knelyng on their knees, besought the Maire and his brothern of their grace.*

1457. Willelmus Canynges.

1458. Willelmus Codre.

1459. Philippus Mede.
Willelmus Damme.

Johannes Wykam.

Johannes Bagod.

\author{
Johannes Jaye. \\ Henricus Chestre. \\ Johannes George. \\ Robertus Bulle. \\ Johannes Haukes. \\ Johannes Jaye.
}

H. $\mathrm{j}^{t i} \times x \times v i j$.

This yere the saide Philip Mede, Maire, sewid byfore the kyng and his counseile al the Lumbards Janueys at that time in Englande, bicause of the takyng of Robert Sturmy and of his shippes. Whiche Janueys, aftir long sewte of the same, were judged and con-

* The Irish were evidently in bad odour in Bristol, for a few years before, in 17. Hen. VI., two severe ordinances were passed by the Common Council, under which no Irishman born might be admitted into the Common Council by the mayor, on penalty of 20l. each from the mayor and from the Irishman. - "Little Red Book," fol. 31 .

CAMD. SOC. 
dempned to pay the saide maire and his brothern the some of $\mathbf{i x} \mathbf{M}^{1}$ marcs, to be paide at certein termes.* And the Sondaye by fore Mighelmas, James Lorde of Audeley was slayne at Blourehethe besides Drayton in the countee of Stafford.

A.D. Maiores.

H. vj"xxxviij. 1460. Thomas Rogers.
Vicecomes.

Robertus Jakys.
Ballivi.

Johannes Gaywodde. Johannes Sey.nte.

This yere the $x^{\text {tus }}$ day of Julhe were slayne at Northampton Humfrey Duke of Buks, John Erle of Shrowisbury, John lorde Bewmont, and Thomas Percy lord Egremont. This same yere, that is to say the Satirday the vij day of Februare, in thentryng of the xxxix yere of Kyng Harry, was slayne at Herforde Oweyn Tydur.

E. iiij"primo. 1461. Willelmus Canynges. Thomas Kempson.

Willelmus Wodyngtone.

Lodvicus Mors.

This yere the Tewisday aftir Chrismas were slayne Richard Duke of Yorke, Richard Erle of Salisbury, and Edmonde Erle of Rutelonde. And this same yere vpon Palme Sonday was the bataille of

* There is so little mention of this affair with the Genoese, that it is worth transcribing Fabyan's account of it here. "In this yere, after some auctours, a marchaunt of Brystowe, named Sturmyn, whiche with his shyp had tranaylyd in dyuerse partyes of Leuaunt and other partyes of the Eest, for so moche as the fame ranne vpon hym that he hadde gotten grene pepyr and other spycys, to have sette and sowen in Englonde, as the fame went, therefore the Januays wayted hym vpon the see, and spoylyd his shyp and other. But this is full lyke to be vntrewe that the Januays shnlde spoyle hym for any suche cause : for there is no nacion in Englonde that delyth so lytle with spicis. But were it for this cause or other, trouth it is that by that nacion an offence was done, for the which all the marchauntys Januays in London were areysted and commyttyd to the Flete, tyll they had founden suffycyent suretye to answere to the premysses. And fynally, for the harmys which theyr nacion had done to the sayde Sturmyn and to this realme, vjM marke was sette to theyr payne to paye; but howe it was payed no mencion I fynde."-Chronicles, Ellis ed. 1811, p. 633. See also Seyer's Mem. Brist. ii. p. 189. 
Ferybrigge, othirwise callid Saxonesfielde,* whiche lyethe bitwene Shirbor and Datkastur, in the whiche batailhe was ovircome Kyng Harry the vjth

[A space is here left for the portrait of Edward IV., which however has never been drawn, the letters of his name only being illuminated above. Under this space is the following.]

This noble prince kyng Edwarde the fourthe in the furst yere of his reigne came furst to Bristowe, where he was ful honourably receyvid in as worshipfull wise as evir he was in eny towne or citee. And there was the same tyme hangid, drawen, and byhedid Sire Bawdon Fulforde knyght $\nmid$ and John Heysaunt esquiere.
A.D. Maiores.
Vicecomes.
Ballivi.

1462. Philippus Mede.

Willelmus Spencer.

Robertus Strange. Henricus Balle. $\ddagger$

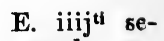
cundo.

This yere the said Philip:Mede maire, bi assent of al the Counseile of Bristowe, was sende vnto the Kynges gode grace for the confirmacioun of the fraunchises and preuilegis of the saide Towne, whiche Maire spedde ful wele with the kynges gode grace, confermyng and ratefieng al the libertees of the said Towne, with newe speciall addicions for thonour and comen wele of the same.§

1463. Johannes Wykam.

1464. Johannes Shipwarde.

1465. Willelmus Codir.
Ricardus Alburtone.

Johannes Hawkys.

Johannes Cogan.
Johannes Foster. Galfridus Greffithes. Willelmus Birde. Walterus Costone. Willelmus Rokys. Johannes Eytone.

* Otherwise the battle of Towton.

† In 1460 "Sir Baudwine Fulforde undertooke on paine of loosing his head that he would destroy the Earle of Warwicke." He then kept his head notwithstanding his failure, but now lost it at the hands of the other side.-Stow's Annals, p. $406 b$.

¥ This name is Broun in the "Little Red Book."

$\S$ The citizens, anxious to make sure of their liberties under the new order of affairs, obtained three charters, the first to confirm the charter of Ric. Il., dated 14 Dec. 1461; the second to secure their peculiar privileges with regard to the Admiralty, 22 Oct. 1461; the third to affirm certain fresh privileges to the city, 12 Feb. 1461.See Seyer's Charters of Bristol, pp, $96-120$. 
A.D. Maiores.

1466. Willelmus Spencer.

E. iij" $^{\text {tijo. }}$
Vicecomes.

Johannes George.

1467. Willelmus Canynges.

Johannes Gaywodde.
Ballivi.

Johannes Shipward, junior. Edmundus Westcotte.

Thomas Rowley. Walterus Grymstede.

This yere the saide William Canynges Maire shulde haue be maried, by the kyng our souerain lordes commaundement as it was saide. Wherefore the said Canynges gave vp the worlde, and in al haste toke ordirs vpon hym of the gode Bisshoppe of Worcestre callid Carpynter, and was made preest and sange his furst masse at Our Lady of Redeclif the yere folouyng, $\mathrm{R}^{\mathrm{s}}$ Jakys beeng Maire, at Whitsontide: and aftir that he was Dean of Westbury certein yeris, and dececid and was buryed worshipfully at Redeclif, by his wife, in the south ende of the medyll yle of the saide churche.

1468. Robertus Jakys.

E. iijti $\mathrm{ix}^{\circ}$.
1469. Philippus Mede.
Johannes Hooper.

Robertus Strange.
Johannes Skrevyn.

Willelmus Wykam.

Johannes Godard. Johannes Nancotone.

This yere was the Bataille of Bambery, where as moche Walsshe people were distrussid.* And there were behedid the lorde Herbert, the lorde Ryvers and his son, and many othirs; and Sire Richard Herbert, a gentil knyght and a manly, was there slayne. And one of the lorde Herbert his brothirn was slayne at Bristowe the same yere at Seynt James tide.

E. $\operatorname{iijij}^{t} x^{0}$.

1470. Johannes Shipwarde.

Willelmus Birde.

Henricus Vaghan.

Johannes Powke.

This yere George Duke of Clarance and Richard Erle of Warwyke, with grete people to the nombre of $\mathrm{v}^{\mathrm{ml}}$, past out of Dertmouth in to Normandy, askyng helpe of the Kyng of Fraunce. And the same yere they came ayen in to Englonde with grete pouer, reryng al the West contray, and came to London, and made Kyng Edwarde to voyde the lande in to Flaundres.

* Spoiled, undone, Cotgrave. 
A.D. Maiores.

1471. Thomas Kempson.
Vicecomes.

Henricus Chestre.
Ballivi.

Johannes Stephins. Willelmus Toket.
E. iijit $^{\mathrm{t}} \mathrm{xj}^{\mathrm{o}}$.

This yere Kyng Edwarde came ayen into Englande vnto London in the Passion woke, and on Estir eve he went out of London with viij $\mathbf{M}^{1}$ men vnto Bernart's fielde, and met with therle of Warwik with $1 \mathbf{M}^{1}$. [The] Kyng hadde the fielde, and there were slayne therle of Warwyk and the lord Mountegewe. Then the kyng retorned to London with kyng Harry, and within xv. daies kyng Harry deied in the Toure. And the same time londid in Devon Quene Marget with Edward hir son, gedering grete people came to Bristowe, and met with kyng Edward at Teuxbury, where the Kyng had the fielde; and there were slayne Edward sonne of Kyng H., therle of Devon, the lord John of Somerset, the lord Wenlok, and many othir knyghtes; and was behedid Duk of Somerset, the lord of S. Jones, with many othir knyghtis; and Quene M. taken.

1472. Johannes Haukes.

1473. Johannes Cogan.

1474. Willelmus Spencer.

1475. Robertus Strange.
Willelmus Wedington. Johannes Penke. Johannes Estirfielde.

Johannes Jaye.

Edmundus Westcotte.

Johannes Forster.
Johannes Gregory. Johannes Gurney.

Johannes Swayne. Thomas Flexalle.

Thomas Hextone. Willelmus Rowley.

This yere cam kyng Edward that noble prynce to Bristowe, and lodged in the Abbey of Seynt Austyns. And the same tyme he had of thenhabitauntz of this Towne and of the contreyes adioynyng a grete benivolence of money gyven hym, to the sustentacion of his werres. And the same yere he passid ovir to Caleis and into Pykardy, and there in that parties of Fraunce he had a comunicacioun with the Frensshe kyng, where they appoyntid and made peace for vij. yere, for the which the seid Frensshe king bere and paid our seid souerain lord yerly a grete tribute of golde.

1476. Willelmus Birde.
Thomas Rowley.
Ricardns Shermone. Johannes Snygge. 
A.D. Maiores.

1477. Johannes Bagod.

1478. Johannes Shipwarde.

1479. Willelmus Spencer.
Vicecomes.

Willelmns Wykam.

Henricus Vaghan.

Johannes Skryvene.
Ballivi.

Johannes Chestre. Philippus Capull.

Johannes Batkok. Clemens Wilshire.

Johannes Druez. Ricardus Bonde.

1483. Robertus Strange, Maior.

E. iiijt xxijo. This yere the viijth day of Aprile the king Edward the iiijth dyed at Westminster, and was buryed at Wyndsore the xix ${ }^{\text {th }}$ day of the same moneth, and on Sonday the vijth day of Jule then next ensewing Richard Duc of Gloucester, brother to the saide king Edward, was made king and crowned at Westminster.

1484.

Henricus Vaghan, Maior.

R.tercijprimo. This yere, the $\mathrm{xv}^{\text {th }}$ day of Octobre, was the grettest flode and the grettist wynde at Bristowe and in the cuntrey there abouts that euer was seen, and grete hurt doon in merchaunts sellers in wode and salt; shippes lost at Kyngrode, the Anthony of Bristowe and a ship of Bilbowe set a lond at Holow bakkes, and other botes and cokkes lost; Saltmerssh drowned, corne, catell, and houses borne awey with the see, and moche people drowned, to the noumebre of CC. and mo. And sone after Herry Duc of Buks was bihedded at Sarum.

* And this yere the two sonnes of King E. were put to scylence in the Towre of London.

1485.

Willelmus Wikeham, Maior.

R. tercij se- This yere Harry Erle of Richmount londed at Milford Haven in Wales, and sone after he' mette with King Richard at Bosworth feld, and there gate the feld of King Richard, the $\mathrm{xxij}^{\text {th }}$ day of August, where the same King Richard was slayne. And sone after there was a sodeyn sikenes in all places

* This is written by Ricart in the margin, as though he had gone on and forgotten it. 
of Englond, called the sweting syknes, wherof moche people dyed.

Edmundus Wescote, Maior.

1486.

This yere the saide Edmond Wescote, Maire, dyed within xv. Anno primo daies after Mighelmas. And Herry Vaghan was elect into his Henrici seprome. And this yere the King maryed Elizabeth the eldest doughtir of King E. the iiijth.

Willelmus Wykham, Maior.

1487.

This yere the Quene was crowned. And a felde was made this H. vij secundo yere ageinst the king by therle of Lyncoln, the Lord Louell, and Martyn Swarte, and they all wer slayne.

Johannes Esterfeld, Maior.

1488.

This yere a grete ship called the Anthony of Bristowe was lost at $\mathrm{H}$. vij tercio. Kingrode, in defaute of the M[aster] of the same ship. And this yer the prince Arthur was borne at Winchester.*

Johannes Penke, Maior.

1489.

This yere the Kyng sent an army of vij $\mathbf{M}^{1}$ men into Brytaign $\mathbf{H}$. vij quarto. to socour the Duches of Britaign. Also this yere the king sent for the Maire, Shiref, and Baillifes to come to his grace to London. And they brought vp with them ij. men of Waterford bicause the Baillifs had taken them and imprisoned them for brynging of Irissh money to the town. $\dagger$

Robertus Strange, Maior.

This yere the brigge vpon the Were was newe made.

1490.

Johannes Stephens, Maior.

H. vij quinto.

1491.

This yere dyuers stretes in Bristowe were new paved, $\mathrm{p}^{\mathrm{t}}$ is to say $\mathrm{H}$. vij $\mathrm{vj}^{\mathrm{t}}$. Horsstrete, Knightsmyth strete, Brode strete, Highe strete, Redclif strete, Seynt Thomas strete, Temple strete, Towker strete, the Bak,

* Holinshed places this event in 1488, Fabyan in 1486.

+ In 1 Hen. VII. a proclamation had been issued providing a remedy for the complaints that were made against the silver money coined in Ireland, which was henceforth only to be coined in Dublin and Waterford. Irish money was frequently however a source of difference.-See Letters and Papers of Rich. III. and Hen. VII. (Rolls Series,) ed. Gairdner, vol. ii. pp. 286, 372, 377. 
Baft strete, Seynt Mary strete, Lewensmede.* And the High Crosse was peynted and gilt, which cost $\mathbf{x x}^{\text {li }}$. This yer the King was at Bristow wher he had a beniuolence of $\mathbf{x v i i j ~} \mathrm{C}^{\mathrm{li}}$. Also this yere Mathew Jubbes purchaced a ground of the town in Seynt Nicholas strete for terme of [blank].

1492.

H. vij vijo. Willelmus Toker, Maior.

This yere the King went to Calice with a grete armye ageynst Fraunce. But peace was made withoute bataille.

1493. Clemens Wilteshire, Maior.

H. vij viijto. This yere the saide Clement Wilteshire deyed and John Hawkes was elected to occupy oute his rome.

1495.

H. $\operatorname{vij} \mathbf{x}^{\circ}$.

1496.

H. $v i j \mathbf{x j}^{\circ}$.

Johannes Esterfeld, Maior.

This yere Sir William Stanley, Lord Chamberlain, was biheddid. Willelmus Regent, Maior.

This yere the King and Qwene came to Bristowe with dyuers lordes spiritual and temporall. And this yere the Duc of Bedford, the kinges vncle, decessid at Thornbury, on whois sowle God have mercy, and was buryed at Keynesham. And the saide Maire and his brethren met with the saide Duc in Kyngeswode with ij $\mathbf{M}^{1}$ men on horsbake, all in blake gownes, and so brought his body to Keynesham, for the which the saide Maire and his brethern had grete thankes of the King.

$1497 . \quad J o h a n n e s$ Drewes, Maior.

H. vij xijo. This yere the Cornyshmen rebelled ageynst the King, and the lord Awdley arose with them. And the King met with them at Blak heth, and ther had victory of his enemyes rebelles, and the saide lorde Awdley was taken ther and behedded at [Tower Hill]. $\dagger$ The same lord when he was at Wells with the blak smyth callid Mighell Josef, Capteyn of the Cornysh

* The Private Act 3 Hen. VII. c. 9 (1488-9), was passed "for the Mayor, Sheriffs, Bailiffs, and Commonalty of the Town of Bristol, for paving of the streets there."-See Rolls of Parliament, vol. vi. pp. 390, 391.

$\dagger$ This is left blank in the MS. 
men, hauyng with them $\mathrm{xl} \mathrm{M}^{1}$ men, sent to the Maire of Bristowe to ordeign loddgyng and vitaill for $\mathrm{xx} \mathrm{M}^{1}$. But the Maire sent them worde $\mathrm{b}^{\mathrm{t}}$ they shuld come no nere, and if they wold come ner, at their oune aduentur. And then the Maire mustred and made redy to withstond the said rebelles, and garnished the town walles with men harnessid and with gonnes, and brought shippes and botes aboute the mersshe, garnisshed with men, artillery, and gonnes. And the said rebelles hereng of this chaunged theire purpose, and toke anoper wey.*.

Johannes Shipman, Maior.

1522.

$\dagger$ This yere whete, corn, and other graynes rose at a dire price, by reason whereof the said Maire, of his gode disposition inclynyng his charitie towardes the comen wele and profite of this Towne, auctorized Mr. Ware and others, vndre the comon seale of this said towne, to provide whete, corn, and other graynys necessary and beneficiall for the comons of this same towne, within the shire of Worcestre, or therabout, by vertue of the kynges moost gratious lettrez patentz to the said Maire, at his meke supplication graunted; by reason wherof greate abundaunce of whete, corn, and other graynes was so provided, that the inhabitauntes of the said towne were greatly releved and comforted in mynysshing of the price of whete, corn, and other graynys, sold in the open markett of this said Towne.

Willelmus Wosley, Maior.

1523.

Md. that the first day of Aprill, in the xiijth yere of the reign of H. viij xiiijo. kyng Henry the VIII ${ }^{\text {th }}$, Clement Bays, Robert Salbrige, William Shipman, Robert Avyntry, Robert .Ellyott, and Roger Cooke, late Shrifs of this Towne of Bristowe, came before the said Maire, Shrifs, and Comen Counsaill then assembled in the Counsaille house of the same towne; and then and there every of theym paid vnto the for-

* The names of officers for the remaining thirteen years of Henry the Seventh's reign seem to be in Ricart's hand, and there he laid down the pen; no further events, save the death of the sheriff in 1506 , were recorded by him for those years.

+ The writing here changes to an extremely minute, though tolerably clear hand.

CAMD. SOC.

$\mathbf{H}$ 
named Maire, to thuse of the Chambre of the said Towne, towardez the chargez and expensis of the knyghtes of the shere and burgeises of the Parliament, at euery tyme as the Parliament shall be holden, xx s., according to thact therof made the iiijth day of Octobre, in the $x j$ yere of the reign of kyng Henry the VIII ${ }^{\text {th }}$ forsaid, in the tyme of John Willyams, Maire then being; as in the same act more plainly appereth.*

1524.

Johannes Wilkyns, Maior.

H. viij $\mathbf{x} \mathbf{v}^{0}$.

This yere the xviijth daie of Marche, Maister Pollard, oon of the kynges Justicez of his Comon place of Westminster, satte with the said Maire in the Guyhald of Bristowe, by reason of a nisi prius suyd by oon Anthony Bridgegode agaynst Robert Elyott, late oon of the Shrifs of Bristowe, vpon an accion of dette of $\mathbf{x x}^{\mathrm{li}}$, affirmed vpon the statute of kyng Henry the vij ${ }^{\text {th }}$ in the xix $^{\text {th }}$ yere of his reign, for the distreignyng and takyng of custome named Scavage or Sewage, $\uparrow$ of oon Morice, bochor, whereof treuth it was founden by the veredict of xij men in the said Guyhald, that the said custome was taken by the same late shrife for kayage, and not for scavage or sewage, as in the

* In 11 Hen. VIII. a dispute between a late sheriff and the Corporation was carried before the Star Chamber, as to the yearly charges to be borne by the Sheriffs, a record of which is kept in "The Great White Book of Records," fos. 48-58. Three lists of charges are entered, in the earliest of which there is allowed for the " costes of the parliament," "by estymacion," $£ 16168$.; in the second, being the schedule appended to the complaint, "To the knyghts of the shere, $£ 10$;" and in the third, contained in the Ordinance of Common Council of 4 Oct. above cited, which settled what future charges should be, "The sherifs shall bere and pay yerely to the Chambre of Bristowe, towardes the charges and expens of the knyghtes of the shere and burgeises of the parlyament, agaynst suche tyme as any parlyament shall be holden, xls." (fo. 57.) The sums paid above were thus the arrears for three years. There had been two Sheriffs since 16 Hen. VII.

† By 19 Hen. VII. c. viii. it was enacted that mayors and officers of cities, boroughs, and towns, must not take the custom called skavage or shewage (payable by strangers) from merchants denizen for their merchandize, under the penalty of £.20. Scavage was a toll taken by cities, towns, and boroughs, of merchant strangers, for wares shewed or offered for sale within their liberties.-Blount's Law Dict. 
copy of the record therof.inrollid in the which boke, ff. cclxxj, more plainly at large appereth.*.

Johannes Hutton, Maior.

1525.

This yere Maister Maire, as well with his costes as with the costez of the comons of this wurshipfull Towne, caused to be taken downe Stalenge Crosse, beyng right old, corrupt, and feble, and caused the Crosse there nowe to be made of the newe; not oonly that Crosse, but also he commaunded that the heddes of the crosses at the galowes and markett place shuld be made of the newe, as they nowe be.

Johannes Ware, Maior.

1528.

This yere the Pryncesse directed hir discrete lettres vnto the said Maire, commaundyng hym by the same that he shuld appere in proper person or by his attorney before hir consaill at Ludlowe, the xvjth day of May, and to bryng with hym Sir John Popley, Clerk, at the sute of oon Galyurd de Brassaley, bycause the said Maire attached nott the same Sir John by hir former letters to hym before directed. And thervpon William Chestre and John Collys, by commaundement of the said Maire, rode to Ludlowe, and there appered accordingly. And for asmoch as the said Maire, by his attorneys, there pleded that the Towne of Bristowe is exempt and not comprised within othir auctorite or jurisdiccion, $\uparrow$ which there was evidently proved, therefore the said Maire was clerely dismyssed and discharged, as well of his apparance as of Sir John Popley above named.

Thomas White, Maior.

This yere $\ddagger$ dyuers burgeises of Tewkesbury in the name of all the burgeisez, there being of their part Sir William Kyngeston knyght,

1531.

H. viij xxij.

* I have searched for this record, but without success.

$\dagger$ The Court of the President and Council of Wales and the Marches held its sittings at Ludlow; the Princess Mary (there being no Prince of Wales) was now at its head. It claimed to have jurisdiction over four English counties, of which Gloucestershire was one. But under the charter of Edward III. Bristol had been made into a county of itself, with its own officers of justice and jurisdiction.

$\ddagger$ An entry is here made of the death of one of the sheriffs, and the choice of another to fill the vacancy. 
Mr. Maideston, and others, mette with the said Maire at Neweport the xxiiijth day of August, and there it was condescended and agreed by way of arbitrement, made by the said Maire and Sir William Kyngeston, that the inhabitaunts of Tewekesbury shall pay to the Shrifs of Bristowe for the tyme being, half custume for kayage and murage, as more largely appereth in an Act therof made the $\mathbf{x v}^{\text {th }}$ day of January, $A^{0}$ regni regis $H$. VIII. xxiijj ${ }^{\text {to }}$, in the tyme of Clement Bays, Maire. The copy of the chartre of Tewkesbury forsaid is inrolled in the white boke, fo. cclxxj.

1532. Thomas Pacy, Maior.

H. viij xxiijo. This yere, for as moche as Robert Poole and Thomas Bell, Shrifs of the Towne of Gloucester, not oonly stopped and stayed iij wayes and $\mathrm{vj}$ busshels of whete and corne, bought and provided by oon Robert Granger to and for thuse of Thomas White, Maire of this towne, and cominaltie of the same, in tyme of scarsenes, but also without auctorite made sale of the said whete and corne, by the commaundment of William Hassard, Maire of the said Towne of Gloucestre; Therfore it was decreed in the Sterre Chambre that the said Shrifs shuld delyuer at the said Towne of Bristowe, to thuse of the same Towne, a thisside the Feest of the Nativite of our Lord next ensuyng, iij Wayes and vj busshels of whete and corne, and that they shuld pay to the Maire and Cominaltee of Bristowe vjli. xiij s. iiij d. for costes. And further that a subpena shuld be awarded agaynst the said maire of Gloucestre. For which premissez to be appeised the fornamed Robert Poole and Thomas Bell the same whete, corn, and money truly delyuerd and paid accordingly. Which decre is inrolled in the White Boke, fo. cclxxij.

Item, this yere the drapery worke in tymbre and the paynted or stayned clothes were made and ordeigned within the Comptoir of the comen audience of the said Maire.*.

* The following items for work done on this occasion are taken from the " Audit Book" of the Corporation for 1532 (the earliest of those books in existence), being part of the account for the " $\mathrm{ix}^{\text {th }}$ weke of the iijith quarter," that is, about the 
Clemens Bays, Maior.

1533.

[Under this date are recorded the marriage of the King and the coronation of $\mathrm{H}$. viij xxiijo ${ }^{\circ}$. the Queen.]

Willelmus Shipman, Maior.

1534.

This yere M. Maire and Cominaltie of this Towne of Bristowe haue received of Emanuel Lucar, Executor of the testament and last will of Rubert Thorne, late of London, merchauntailor, decessid, ccccc li. sterling to thentent to socour yong men which ar full mynded to make cloth within the same Towne, according to the said testament and last will. Thordynance wherof appereth in the Boke of Ordenaunces in the tyme of the said Maire the xxij day of January, Anno r. r. H. VIII. $\mathbf{x x v}^{\text {to }}$; whiche $\mathbf{c c c c c}$ li. were devided accordingly, and seuerall obligacions therof made and delyuerede vnto Gilbert Cogan, Chambrelayn of the same Towne, for the due execution of the Testament and will abouementioned.

Rogerus Coke, Maior.

1535.

This yere the xviijth day of August, the kynges highnesse had his H. viij $x \times v j^{\text {to }}$. repaire for hym and his trayne vnto his manor of Thornebury, and there contynued by $x$ dayes. And for asmoche as his moost noble grace then fully determined that his highnes wold not resort vnto this his Towne of Bristowe, bycause the'Plage of pestilence then reigned within the said Towne; Therfor M. Thomas White and M. Nicholas Thorne with M. Chamberlayne, by the consent of M. Maire aboue-

fourth week in August. The Tolsill or Tolsey, otherwise the Counter or Comptoir, was where the Mayor held his court; the View of Frankpledge, and other public business, took place at the Guildhall (see after, Quartum Principale):

"Item, $\mathrm{p}^{\mathrm{d}}$ for bordde nailys, cawfoote nailys, and hache nailys, for the werke at the tolsill

Item, $\mathrm{p}^{\mathrm{d}}$ for ix bewdeley borddes for the crestes, after iij the bordde

Item, paied for tacke nailys, and racke hookes to fastyn the staynyd clothes at the tolsill

Item, $\mathrm{p}^{\mathrm{d}}$ to $\mathrm{W}$. Kelke for $\mathrm{v}$ yardes for to be stayned for the tolsill .

Item, $\mathrm{p}^{\mathrm{d}}$ for $\mathrm{ij}$ new payre of gymmewys for bothe the new dorrys at the tolsill

Item $\mathrm{p}^{\mathrm{d}}$ for a lache and a cache $\mathrm{w}^{\mathrm{t}}$ avise

Item, $\mathrm{p}^{\mathrm{d}}$ for another lache $\mathrm{w}^{\mathrm{t}}$ a ryng apon it

vij d.

ij s. iij d.

iiij d.

0 s. $0 \mathrm{~d}$.

$\mathrm{xxd}$.

iiij d.

v d." 
said, and the comen Counsaill of the saide Towne, the $\mathbf{x x}$ day of August aboue remembred resorted vnto the forsaid manor, and there in the name of M. Maire abouesaid and the Cominaltie of this said Towne, presented vnto the kynges high maiestye $\mathrm{x}$ fatte oxen and $\mathrm{xl}$ shepe towardes his moost honorable houshold, and to the right excellent Quene Anne oon cuppe with a cover of siluer ouergilt, waiyng xxvij vnces, with $\mathbf{c}$ marks of gold within the same cuppe, as a gifte of this the kynges Towne and hir Chambre of Bristowe, hir grace then promysing to demaund or haue noon other gifte but oonly that, if hir said grace wold resorte to this said Towne at any tyme therafter.*

1538. Willelmus Chester, Maior.

H. viij xxixo. $\quad M^{d}$. that this yere the $x i^{\text {th }}$ day of Octobre our right famous Prince was borne of the moost gratious Quene Jane at Hampton Court, to the ineffable joy, consolation, and comfort of all this noble realme. And within the chappell of Hampton Court forsaid, the Moneday next ensuyng, beyng the $\mathrm{xv}^{\text {th }}$ day of Octobre aboue specified, abowte xij at the clok of the same day, was with high and condigne solemnite cristened. Whos godefaders were the bisshop of Canterbury and the right honorable the Duke of Northfolke, with the right prudent Lady Mary, godmother; whiche named this moost excellent Prince, by the high providence of God procreated and lawfully producted, Edward, whos lyf to contynue all this said realme and others have greate cause for to pray, \&c. $\dagger$

This yere was laste thofferyng on Mighelmas day at S. Mighells.

* See after, p. 65; and the Petition to Henrietta Maria as to the Castle, where Bristol is called the "Queen's Chamber, as London is called the King's Chamber." The citizens of London made use of that title in their address to Richard II. on his succession to the throne. Stowe's Annals, ed. 1614, p. 277. The gift mentioned above as given to Anna Bulleyn seems to have been of the nature of Queen-Gold, an ancient revenue accruing to every Queen Consort. See Prynne's elaborate treatise, Aurum Regina, 1668, especially pp. 2, 122-126.

. A full account of the christening of Edward VI. is to be found in the British Museum, Add. MS. 6113, fo. 81. In explanation of Ricart's date of the birth, 1538, instead of 1537 as usually given, see Introduction, touching dates of mayors. 
Thomas Jeffrezs, Maior.

1539.

Md. that this yere, the $\mathbf{x v}^{\text {th }}$ day of May, a Scott named George H. viij $x x x^{\circ}$, Wysard * sett furth his lecture in S. Nicholas church of Bristowe, the moost blasphemous heresy that euer was herd, openly declaryng that Christ nother hath nor coulde merite for hym ne yett for vs. Wich heresy brought many of the Comons of this Towne into a greate errour, and dyuers of theym were persuaded by that heraticall lecture to heresy. Wherupon the said stiffnecked Scott was accused by M. John Kerne, Deane of this Diocese of Worcestre, and soone after he was send to the moost reuerend Father in God the Archbisshop of Canterbury, before whom and others, that is to singnyfie, the Bishops of Bathe, Norwhiche, and Chechester, with others as doctors, \&c. And he bifore theym was examyned, conuicted and condemned in and vpon the detestable heresy aboue mentioned. Wherupon he was inioyned to bere a Fagott in S. Nicholas church forsaid and [about] the parisshe of the same, the xiijth day of July Anno predicto; and in Christeschurch and parisshe therof, the $x^{\text {th }}$ day of July abouesaid. Which Iniunction was duely executed in forme forsaid.

Md. that this yere all the Fryers of this Towne surrendid their places vnto the kynges moost high maiestiez hands. $†$

Johannes Spryng, Maior.

1540.

$M^{d}$. that this yere the Abbott and Conuent of Seynt Augustynes H. viij xxxjo. of Bristowe surrendred that monastry vnto the kynges moost noble graces handes. $f$ And so in like wise the maister and his brothers of Gauntez, with theire assentz made.

* This incident in the life of the martyr Wishart is mentioned in R. Chambers' Biographical Dictionary of Eminent Scotsmen. The fact that he preached at Bristol is referred to in the sketch of his life given in Rose's Biographical Dictionary, but among a great number of accounts these are the only two that refer to it.

† In the "Suppression of the Monasteries," Camd. Soc. pp. 196, 210, are two Letters from the Bishop of Dover to Cromwell, relating, among others, to the surrender of the religious houses of Bristol.

$\ddagger$ By letters patent, dated 4 June, 34 Hen.VIII.(1542) Bristol was made a bishopric, with St. Augustine's church for a cathedral, and the town erected to the dignity of a city. Fo. 226 of the MS. contains a copy of the first and the last or operative 
$M^{d}$. That this yere the scite and the demeanes of the Gauntes* of Bristowe, then dissolued, with all manors, londez, tenementes, and other the hereditamentz belonging to the same, were purchased by the Maior and Cominaltie of Bristowe abouementioned of the kynges highnes, for the summe of $\mathbf{m}^{1}$ li., wherof $\mathrm{vj} \mathbf{c}$ li. were paid in parte of payment this yere vnto Edward North, Esquyer, Treasorer of the Court of Augmentations.

1543.

H. viij xxxiiijto.

Henricus Whyte, Maior.

This yere xiiij. days before Myghelmas the said Harry Whyte, mayor, dyed. $\quad$ nd John Repe was chosen to supplye his rome.

And this yere in the tyme of the said John Repe beyng mayor, the xvijth day of Septembre, the Erle of Surrey, the Duke of Norfolk's son and heire apparant, came to Bristowe, and was

parts of this document: it does not occupy quite the whole of the page, but it appears to have been an official copy, as after the words "per breve de privato sigillo, data prædicta, aucthoritate parliamenti" is the autograph signature "Martyn." Another copy of the same length, and with the same signature, is in the "Great White Book of Records," fo. $299 b$.

The entire document is in Rymer's Fœdera.

* According to Tanner (Notitia, Bristol, No. 11) the founder of this house, Maurice de Gaunt, put it under the management of the canons of St. Augustine's, but afterwards his nephew made it into a separate house, with a master and three chaplains. Not quite fifty years before the surrender in 1540, there had been a great "variance" between the abbot of St. Angustine's and the mayor and sheriffs of Bristol, in which some of the principal matters in dispute concerned the " house of Seint Marke of Billeswyk, and the precincte of same called the Gauntes, adjoyning unto [Seint Austyn's] grene," touching (among other things) the right to hold a leet or law-day within the precincts of the monastery of St. Augustine's, and also to whom suit was owing from the precincts of the Gaunts or Gauntis-side. The records of the "bills" "and " replications," \&c. in this "variance," which was settled by mediation of the Archbishop of Canterbury and the Chief Justice of the King's Bench in 1496 (11 Hen. VII.), are contained in the first several leaves of the "Great White Book of Records," belonging to the Corporation of Bristol.

In later days a hospital was founded "at the Gaunts" for "poore fatherless children," by Wm. Bird, Mayor, out of money left in 1586 for that purpose by John Carr, merchant of Bristol (see after, p. 62). See as to the family of the founder, and further as to the history of the house, Barrett's History of Bristol, pp. 352-376. 
receved by the mayor and thaldremen of the saide citie vpon the Brige of Bristowe, and so they gave hym a bankett.

Willelmus.Jay, Maior.

1550.

In this yere the new Tolsel * was buylte, and in that same yere was $\mathbf{A n}^{\circ} \mathbf{E} \mathbf{v i}^{\mathrm{il}} \mathrm{ijj}^{\circ}$. the stipe strete goieng vp to Saincte Michaells was brought lower and in good fassion. Also in this yere, was Redclif strete, Saincte Thomas strete, new pight. $\dagger$ In this yere there was an order taken aboute the admaraltie, that all straungers that take ankerage of vs beyond the see, they shoulde paie like ankerage here.

Willielmus Pepwall, Maior.

1568.

In this yere a new Cutt was made in the ryver of Bridgwater, within the Lordshipp of Hamp iuxta Bridgwater belongyng to this citie; by Anno Elizabeth $\mathbf{x}^{\mathrm{mo}}$. reason of a grete compasse or fetch abowt of the water of the said ryver, the sea bancks or walls of the said ryver vpon the north-east side therof, nighe to a tenement in the tenure of Roger Popham, was so decayed and so worne (not withstonding yerlie reparaciouns therof doune to no small charge), that if the sea shuld haue broken over, wherof the inhabitauntes of the countries nighe the same werre in grete feare, it would haue drowned above $\mathrm{x} \mathrm{m}^{1}$ acres of ground, beside other grete harmes would haue ensewed thereof. It was therfore prevented and forseen by the Commyssioners of the Sewars, $\ddagger$ namelie, Sir Hughe Powlet knight, Sir George Speke knight, $\S$ Sir Morrys Berckley knight, Mr. Humfrey Coles esquier, Mr. Henry Portnam

* See before, p. 53. + i.e. pitched, the local word for paved.

¥ A Decree, dated 17 Sept. 9 Eliz., in the matter of these Sewers is recorded in the Great White Book of Records, fo. 318b. Another old MS., copying this entry, has "Sea-walles" instead of "Sewars." (Seyer's Mem. Bristol, ii. 240.) The word is here used in its true and original sense, and this orthography carries it back to its derivation. (See Toulmin Smith's "Laws of England relating to Public Health," 1848 , pp. 67,80 .)

$\S$ Sheriff of the counties of Somerset and Dorset in 1562 (Harl. MS. 1385, fo. 1). His son, George Speke, esq. was Sheriff of Dorset in 1592. For an interesting sketch of the Speke family see "Trotandot's Rambles" by Mr. G. P. R. Pulman, 1870 , p. 95.

CAMD. SOC. 
esquier, and manie other of the said commyssion, with thadvise of the best heads of good yomen of the said countrie, that a new Cutt shüld be cut straight over.

1571.

Elizabeth xiijo.

Willelmus Tucker, Maior.

In this yere the markett in Sainte Thomas strete, for wooll and yarne and cattall, to be kept on euerye Thursday, was purchesed in the name of the Maior and Cominaltie.

$1572 . \quad J o h a n n e s$ Stone, Maior.

Eliz. xiiijo. [Execution of the Duke of Norfolk in June; exchange of ambassadors-Lord Clynton and "Mons. Memaranse"-between England and France "for the establishinge a leage of peace."]

1573. Johannes Browne, Maior.

Elizabeth $\mathbf{x v}^{\text {to. }}$ This Maior caused a good reformacion to be made for mesures of barrells and kilderkins, which weare made larger and of a bigger assise then they weare before. And the old vessells repelled.

1574. Thomas Kelke, Maior.

Flizabeth xvjto.

This yere on Satterday, beinge the xiiijth day of August, the Queene came to this citie, and Mr. Maior and the Common Counsell ridinge with foote clothes, receaved her highnes within Laffardes gate. And ther Mr. Maior delyvered the gilt Mace vnto her Maiestie, and she then presentelie delyvered it to him againe. And so Mr. Maior knelinge whiles Mr. John Popham esquier, Recorder of this citie, made an Oracon, did after it was ended stand $\mathrm{vp}$, and delyvered a faire purse wrought with silke and golde having an hundred poundes in gold in it, vnto her highnes. And therevpon Mr. Maior and his bretheren toke theire horses, and Mr. Maior rode nighe before the Queene betwene two Sergantes-at-armes. And the residewe of the Common Counsell rode next afore the Nobilitie and Trumpeters, and so passed throughe the towne vnto Mr. John Yonges howse, where she lay vntill Satterday then next followinge, on which day a litle before her Maiesties departure hence she made five knightes,-(that is) the said Sir John Yonge, Sir Richard Barkeley of Stoke, Mr. Tracie, Sir Thomas Porter, and Sir William Morgan of Penycoite. 
And duringe her abode here (amonge other thinges devised for plesure) there weare iiij c. soldiers in one sute of apparell, whereof iij c. weare harquebussiers and $\mathrm{j} \mathrm{c}$. pikemen in corselettes. Also there was made a greate large forte standinge in Trenemill meade over againste Gibtaylor, which was assaulted. by land and water iij. daies. And there was also another litle forte called the base fortt, standinge upon the hill beyond, which was wonne the first night that the assault was given. And the Queene was there at euerie assault duringe the saide iij. daies, for whose standinge there was builded a large scaffolde of tymber in the Marshe. Whiche martiall experiment beinge verie costlie and chargeable (especially in gonnepowder), the Queene and Nobilitie liked verie well of, and gaue Mr. Maior and his brethren greate thankes for thcire doinges.*

Georgius Snygge, Maior.

1575.

This yeare began the plage to be very hott aboute St. James tyde, $\begin{gathered}\text { Elizabeth } \\ \text { xvijmo. }\end{gathered}$ and betweene St. James tyde and Powles tyde $\uparrow$ there died aboute 2,000 persons.

Johannes Prewett, Maior.

1576.

In this yeere a shipp of Bristoll named the Peter, beinge of 220 Eliz. xviijo. ton, laden with oyles, secks, $\ddagger$ and other merchandizes was loste and caste awaie within xij. myles of the Cittye, and of all the men butt

* A longer account of this entertainment is quoted in Nichols" "Progresses of Elizabeth," i. 393-406, from "Churchyard's Chips" published in 1575. A prayer by the Queen on this occasion, "giving thanks for her preservation on that long and dangerous journey," is also extant. (See Calendar of State Papers, Domestic, sub. 1574, p. 486, No. 13.)

+ i.e. between July 25 and January 25.

¥ Secks, or sack, and bastard, a kind of sweet muscadel, coming, as is here said, from Spain, may be both found noticed among other medixval wines in "The Babees Book: Manners and Meals of the Olden Time," ed. by F. J. Furnivall for the Early English Text Society, 1868, p. 205. "These hote wynes, as Malmsey, wyne corse, wyne greke, Romanyke, Romney, Secke, Alygaune, Basterde," \&c. Andrew Borde, quoted $i b$. 
iiij. saved; the shippe of Tho. Williams, merchante, and most parte of the goods lost and taken awaie.

1577.

Eliz. xix

Johannes Wade, Maior.

In this yeere came from Andoluzia suche sweete and pleasant secks* ingenerall as by reporte the like was neuer knowen, as pleasant as bastards.*

1578. Thomas Colstone, Maior.

Eliz. $x^{m}{ }^{m o}$. In this yeere here arived in October a greate shipp and a small barke from Cataye, laden with golde ore estemed to be very riche, and was putt into the Castle to be refyned and keept, butt after was sent to London and litle estemed and not worth the chardges. $\dagger$

1579. Johannes Roberts, Maior.

Eliz. $\mathrm{xxj}^{\circ}$. In this yeere beinge the $\mathrm{xxv}^{\text {th }} \ddagger$ the shipp called the Golden Lyon $\ddagger$ Sic. of Bristoll, beinge of the burthen of v c. ton and also accordingelie appoynted, came from Andoluzia but not all laden, and beinge in Hungrode, for lake of good attendance and want of anckers and suche like, was overthrowen and soncke in the river, and by her ouerthrowinge did sincke a new hulke which was mored by her, the which hulke was of iiij c. ton, soe that the river was in greate dainger vtterlye to haue pirished, yfe greate and diligent care had not bene presentlie executed by the Maior and Comminaltie, who gave greate enterprises with shipps caskes, liters, and bootes, to recouer the same, yet notwithstandinge all attempts coulde not in halfe a yeere remove her.

1580. [Rebellion of Desmond, "hee and his brother were proclaymed traytors."]

Eliz. xxij․

1581.

Nliz. xxiijo.

[Arrival in London, by way of Ireland, of "many of the most noble men in Fraunce. * * * After iij. weeks they retorned."]

* See note, p. 59.

$\dagger$ This refers to one of Frobisher's voyages. (See State Papers, Domestic, Eliz. vol. 126, Nos. 20, 21, 22.) Two of his ships had unladed at Bristol the year before, and many curious details as to the ore and its trial are preserved in the State Paper Office. (See Calendar of State Papers, Domestic, 1547-1580, pp. 556, 602, \&c.) 
Philippus Langley, Maior.

1582.

In Marche the Erle of Pembroke was receaued into Bristoll Eliz. xxiiijo. honorablie with lx. horsemen of honest burgesses, the Maior with the Aldermen and comon Counsell receaued him in Wyne streete, and then wente to the Tolsey and there stayed vntill one Mr. Temple had ended his oration in Latten.

Thomas Aldworth, Maior.

1583.

[After a note of the death of Robert Halton, one of the Common Conncil, another Eliz. xxv ${ }^{\text {to }}$. and later hand has written the following.]

On the front of the Pomell of the Sundays Sword is Qu. Eliz: arms, on the Reverse a Cross, 1583.

On the Exergue:

This Sworde we did repaire,

Thomas Aldworth being Mayor.

Walterus Pyke, Maior.

1584.

This yeere before Christmas were many taken and arrayned in Eliz. xxvj ${ }^{\circ}$. theis countries for conspiracies against our gracious Queene, whome God defende.

Thomas Rowlande, Maior. 1585.

This [year] the $\mathrm{ix}^{\text {th }}$ of November Mr. Richard Cole was chosen Eliz. xxvijo. burgesse of the parliament by the ffreeholders of this Cittie. Alsoe one Frogmorton attaynted of treason was drawen, hanged, and quartered. Alsoe one Thomas Parry, a notorious traytor to the Queenes $\mathrm{ma}^{\text {tie }}$, who conspired her death, was alsoe hanged and quartered.

Ricardus Cole, Maior. 1586.

This yeere there was provided by Thomas Aldworth, alderman, Eliz. xxviijo. and James Cullimore of London, haberdasher, v. shippes laden with corne out of Lyne and Boston, with wheate, rye, malte, and barley, to the valew of 2,600 li. worth, and brought to the Cittie of Bristoll at the chardge of the saied Thomas and James, and did relive Wales 
vp Seavorne, and the country about vs, to the great comfort of all the people.

[John Carre, merchant of Bristol, died and left lands for building " an Hospitall in the Cittie for the bringing $\mathrm{vp}$ of poore fatherlesse children." Names of the executors given.]

1588.

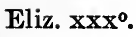

John Barnes, Maior.

In this yeere the Queene of Scots was beheded, and a great many traytors alsoe hanged for treason against her majestie.

Alsoe thys yeere the Spanyshe army came to invade this lande with a greate Navye of Shipps, but in the end they were fayne to retire home with great lose, bothe of shippes and men and great treasure, whome the lord be praysed for ytt.

1590.

Eliz. xxxijo.

William Birde, Maior.

This yeere aboute iij. weekes in lent, there was presented in the house a patente from her ma ${ }^{\text {tie }}$ as concerneinge a hospitall to be erected by the name of Queene Eliz: Hospitall, yssueinge oute of John Carres landes** Which said Hospitall was the same yeer, by the greate dilligence and charitable endevour of the said William Birde, founded at the Gaunt3, and xij. poore children placed therein for a beginninge of the sayd goode worke, to the which the sayd William Birde was a bountifull benefactor and gave-therevnto 530 li. in money for the advancement thereof.

1594.

Michaell Pepwall, Maior.

Eliz. xxxvjo. This yeere Thomas Aldworth, alderman, did buy to the use of the commones of this Cittie, from Christmas till Mychellmas followinge, 1,200 li. worth of wheate and rye, and did bringe and caused to be brought into the markett euery markett daie a quantitie, and thother daies did serve the Commons of the cittie, to the greate good of the whole comunaltie of the cittie, as by accompt maye be seene.

* The rest of the sentence is in a different hand to that of the foregoing. 
William Parfey, Maior.

1596.

This yeare all manner of Corne was deere, and Mr. John Whit- Eliz. xxxriijo. sune of the Citty of Bristoll, merchant; did buy of Mr. Thomas Offeley of London, merchant, 3000 quarters of Dansk rye for the prouision of this Cittie, which rye ariued here in the moneth of July, and was presently sould, and there was clearely gained thereby seauen hundred pounds, a great part whereof was spent in procuring an Act of Parliament for Ophants [Orphans] causes, Mr. George Snigg, Recorder, and Mr. Alderman Ellis beinge then Burgeises of the Parliament for this Cittie; and the resedue of the money remained to the Mayor and Commonaltie.

William Yate, Maior.

1597.

This yeare likewise all manner of graine was very deere, and the Eliz. xxxix Exor. of Mr. Robert Kitchin, Alderman, gaue weekly 100 marks for the relief of the poore in diuers parishes. More, the said exor. gaue this yeare 20 marks towards the bewtifyinge of the key pipe. This yeare all the men of habilities within this Citty were injoyned to give one meale of meate to poore people euery day, viz. some 8 , some 6 , some 4 , and some 2 , accordinge to their habilitie.

[The City spent $£ 400$ in purchasing and building a new market, out of the rents of which $£ 20$ yearly to be given for placing apprentices.]

[Purchase of lands by John Whitson at Winterborne for the Corporation.]

Radulphus Hurte, Maior.

[Deatb of Elizabeth and coronation of James I. on $25 \mathrm{July}$.]

1598.

Eliz. $x l^{\circ}$.

1602.

Eliz. xliiijo.

1603.

Eliz. xlvo.

This yeere in the moneth of July the greate plague began in this Citie, and contynewed eighteene monethes, and from July vntill the $\mathrm{xxix}^{\text {th }}$ of September followinge there died of the plague one hundred persons or thereabouts.

Johannes Whitson, Maior.

1604.

This yeere there dyed of the plague in this Citie 2,950 persons. Also this yeare vppon the fowerth of October was the greatest snow 
that euer was knowne by the memory of man, which continewed fower dayes, and by reason that the leaues were then vppon the trees very many trees of all sorts, espeacially of fruite trees, were throwne downe by the roots, and the limbs and boughes of many others were broken in pieces.

1605.

Christoferus Kedgwin, Maior.

An $^{\circ}$ secundo

R. Jacobi.

This yeere there dyed of the plague in this Citie 150 persons. Alse this yeere the vij ${ }^{\text {th }}$ of November, Kinge James was proclaymed Kinge of Greate Brittaine, France, and Ireland, by the Towne Clarke of this Citie at the highe Crosse there.

1605.

Thomas James, Maior.

An. tertio Reg. [Short notice of Gunpowder Plot. A basin and ewer, silver gilt, left to the City Jacobi. for the Mayor.]

$1606 . \quad$ Johannes Barker, Maior.

An. quarto R. [Among other entries.]

Jacobi. Also this yeere there was the greatest inundacion that hath bin heard of, which happened on the $\mathrm{xx}^{\text {th }}$ day of January, by reason of the force of the winde blowinge at South south west, by meanes whereof the whole country of Brintmarshe and Saltmarshe and many people and cattell were drowned then, and many merchants of this Citie sustained greate losse in their Sellers vpon suggars, woade, and salte.*

1608. [Visit of the Duke of Lennox to Bristol.

An ${ }^{\circ} \mathbf{j}^{\circ} \mathbf{R}$.

Jacobi.

1609.

$\mathrm{An}^{\circ}$ vijo $R$.

Jacobi.

1612.

[Visit of the Duke of Brunswick on 9th May; he was met by the City officers at the Tolsey, and an oration made nnto him, and was entertained at the White Lyon in Broad Street, by the Mayor, \&c.; " about the middle of supper there were 300 men or thereabouts gave them a volleye of shott."]

Abellus Kitchin, Maior. An $\mathbf{x}^{\circ}$ R. This yeere in the moneth of Aprill the Lord president of Wales, the Lord de la Ware, the Lord Clifton, with divers other knights and gent. with their ladies, came to this cittie, where they were

* A long contemporary account of this inundation is quoted by Seyer, Mem. Bristol, ii. 261. See also Cal. State Papers, Domestic, 1607, p. 348, No. 51. 
accomodated with lodgings and entertainment by the Maior and Sheriff Barker, whoe tooke the same very kindly.

Alsoe this yeare the high and excellente Princes Queen Anne, daughter of the noble Prince Frederick kinge of Denmark and Norway, and syster to Christierne the nowe kinge of those countries, and wyfe to our most deere and dread soueraigne Lord James, kinge of great Brittaine, Fraunce, and Ireland, havinge bin at the cittie of Bathe * for her health and recreacion, was disposed to come from thence to visite this cittie of Bristoll, beinge called and accompted her Mates Chamber; Of whose comminge thither the Maior having some intelligence, did with the advyse of his brethren the Aldermen and Counsell of this cittie make such provision for the receiving and entertaining of her $\mathrm{Ma}^{\text {tie }}$, as could be accomplished vppon soe soddaine and shorte warninge; whervpon he caused all the streets where hir $\mathrm{Ma}^{\text {tie }}$ shoulde passe through the cittie to be sanded, and all the companies of Arts and Misteries, with three bands of trayned souldiers, to the number of 500 souldiers, well apparelled and furnished, vnder the chardge of three captaines, to be in readiness for the attendinge and guardinge of hir highnes through the streats. And soe the Maior, Aldermen, Sherives, and Common Counsell, all in Skarlett gownes, tooke their horses and roade on footclothes from the Tolzey to Laffords gate on Fridaie the fourth of June, where they mett and receaued hir Ma ${ }^{\text {tie }}$, Mr. Laurence Hide, esquier, then Recordor of the cittie, making a brief Oration vnto hir Matie; which beinge ended the Maio $^{r}$, usinge some gratulatory speeches in few wordes, presented vnto hir highnes a faire purse, of satten, imbrodered with two letters for hir name (viz. A. R.), in which purse were 100 vnites $†$ of

* Mention is made of a projected visit to Bath in a letter of Feb. 12. Mrs Green's Calendar of State Papers, Domestic, sub. 1612, p. 119, No. 62. See also Wood's Fasti Oxon. (edit. Bliss,) i. 270, and Nichols's Progresses, \&c., of King James I. vol. ii. p. 643.

+ The unit or unite was a gold coin which was coined in 2nd of James I., and took the place of the sovereign. It seems to have been named to commemorate the

CAMD. SOC. 
gould, amountinge to the summe of 110 li., as a guyfte from the Maior and Commynalty of this Cittie, which hir Matie most gratiously accepted, and soe the Maior and Recordor ${ }^{\mathbf{r}}$ tooke their horses, and the Maior beinge placed betwene two gent. vshers roade next before the lord Carie, whoe roade next vnto hir $\mathrm{Ma}^{\text {ties }}$ charriott, and soe the Maior with his brethren and companie brought hir $\mathrm{Ma}^{\text {tie }}$ to the house of the Ladie Marques, sometime the house of Sir John Younge knight, noe sword beinge [t] hen borne before the Maior (hir Matie beinge guarded by the souldiers as she passed through the streets to the house aforesaid), noe sound of drumme or gunne beinge heard as she passed. But when hir highnes was placed and settled in hir lodging, the bands of souldiers beinge all sett in good order vpon the Kay, they gave a great valley of shott, and imediatlie thervpon there were 60 peeces of greate ordnaunce dischardged neere the Kay, and then the souldiers retorned and dischardged their peeces againe before hir highnes Courte, hir $\mathrm{Ma}^{\text {tie }}$ behoulding hem forthe of hir chamber window and much commending them. And the same night certaine speciall souldiers were sett and appointed to watch and to guarde hir Maties person at the said house. And the next daie, beinge somethinge rainye weather, hir Matie made hir aboade in hir house, Mr. Maior entertaininge many of hir highnes servaunts at dinner in his house, that daie. And on Sundaie following, the Maior, Aldermen, Sherives, and Common Counsell with their officers repaired to hir highnes Courte, and attended hir Matie from thence to the Cathedrall Church of St. Augustines, where she heard the sermon preached by Mr. Doctor Robson, Deane there, and soe retorned to the Courte, being guarded by the souldiers, as hir highnes passed thither. And the next daie, beinge Mundaie, Mr. Maior invited the Lords and Ladies, and other Knightes, whoe dyned at his house, and in the afternoone there was a showe made for pleasure on the river, by a shipp sett union between England and Scotland, as it bore the legend: " Faciam eos in gentem unam." It was raised in value from 20s. to 22s. by Proclamation dated May 18, 1611. 
on and assaulted by two Turkishe Gallies, a scaffold beinge made in Canninges Marsh for hir Matie to behould the same and the takinge of the said shipp in fight by the said Gallies, which her $\mathrm{Ma}^{\text {tie }}$ beheld with great delight. And the same night the Ladie Drumman with other Ladies and gent. being hir Maties servaunts did suppe at Mr. Maio ${ }^{\text {rs }}$ house. And then the Ladie Drumman did deliuer vnto Mr. Maior a ffaire ringe of gould sett with diamonds very richly, as a favor from the Queene $\mathrm{Ma}^{\text {tie }}$. And the next daie hir Ma ${ }^{\text {tie }}$ departed from this Citty to Syston in Gloucestershire to the house of $\mathrm{S}^{\mathrm{r}}$ Henry Billingsly, the Maior with his brethren and the rest of the companies bringinge and attendinge hir highnes to Laffordes gate; and there Mr. Maior and his brethren tooke their leaves of hir Ma ${ }^{\text {tie }}$, whoe gave Mr. Maiour and his brethren greate thankes for hir entertainment, which she most gratiously accepted, and promysed to shew the Cittie anie ffavour in any thinge wherin she might be occasioned to vse the same for their good.

[After this time the entries of events are very few and far between, some few apparently having been inserted quite recently. Under 1634 we find, in a contemporary hand, "This yeare the writ for shipping mony began." In 1646 "there happened a lamentable fire vppon the Bridge of Bristoll, which burnt all the houses on the north part of the bridge, from the Chappell, on both sides, to St. Nicholas Gate, and through the industry of good people it pleased God to put a stop to it, and was shortly after rebuilt." The stirring events of these times elicited no other comment from the recording officer here than that "In the moneth of January, 1648, K. Charles was behedded." This man must have been a Parliamentarian, but a touch of the divisions existing among men in Bristol is here, for immediately beneath is written in quite another hand, " $\mathrm{xxx}^{\circ}$ January 1648, $\mathrm{y}^{\mathrm{e}}$ martyr dyed."]

In the moneth of Feb. 1652, ther was a very desperate fight 1652 betwene the English and Holland fleets vpon the South Coast, the Hollander being 80 men of warr and 200 marchant men, the English not beinge in all 80 sayle, yet after 3 dayes ingagement the Lord gaue the English a glorious victorie, soe that there weare taken of the Douch of their men of war and marchant men, besides what suncke and fyred, aboue sixty sayle: tooke about 1,500 prisoners, and 'tis thought 2,000 and more weare slayne. The Englishe withe lost and what wounded about 450 men, higgayon seluh.* It is to bee * Psalm ix, 16. 
remembred that the Maior, and some of the Aldermen assigned, with other honest Cittizens, vpon the report of this good newes, made a collection through the Cittie for the wounded men, and gathered 200 li. in money, besides much good old lyninge, all which was sent and distributed at Weymoth and othir ports to the wounded seamen. Which charitable act beinge taken notice of by the Parliament, and soe well reseaued by them, that they sent the Cittie the thankes of the howse in letter from the Speaker.*

[The visit of Charles II. and his Queen to the City in 1662, also of James II. on 25 Aug. 1686, are recorded. Under 1687 is recorded the withdrawal of the Charter of the City by James II., and under the following year its restoration, and the consequent change of officers. Nov. $4 \mathrm{th}, 1688$, the landing of the Prince of Orange at Torbay.]

1695. This year a guinea was current at thirty shillings, by debaseing and clipping the silver coin.

1696. This year a mint erected for recovering the hammered silver money.

1698. This year a pile of brick building erected on Broad Key, the first brick building in this City.

\section{Fncipit quartum principale bujus libri.†}

Fo. $153 a$.

Sethin it is so that I, Robert Ricart, Towne Clerke of Bristowe, haue made and devisid this present Boke for a Remembratif, to be named and callid the Maire of Bristowe is Regestre, or ellis the Maires Kallendre, whiche boke is growndid and restith vpon vj principall matiers, as in the begynnyng of this same boke more pleynlier it apperith. Wherof nowe the Fourth Principalle foloweth here, sheweng the laudable costumez of this worshipfull

* "A collection was ordered to be made in the House [of Commons, on reading the news of this victory] for the widows of sailors killed in the action." Cobbett's Parl. Hist., iii. p. 1380.

$\dagger$ This Part, the whole of which is here printed, occupies fos. $152 a$ to $164 b$; and is preceded by the whole-page picture of the induction of the Mayor. 
Towne, and of the eleccion, charge, rule, and demenyng of thonourable Maire, Shiref, Baillifs, and othir officers of the same Towne in thexecuting and guidyng of theire said offices during theire yeres. With other manyfolde fraunchisez, libertees, and diverse comendable vsages and ordenaunces of tyme oute of mynde grauntid, hadde, vsid, and accostumed in the same Towne, as in this boke here folowyng shall be shewid. I therefore the said Towne Clerk, in my most herty maner, exhorte and praye all suche worshipfulle persones as hereafter shall be callid and electid to the seide officez, at theire ceasons of leysoure to rede or do to be redde and overseen this present boke, so that by the ouersight of the same they may the better, sewrer, and more diligenter, execute, obserue, and ministre their said Office3, in assistyng and mayntenyng the fraunchise3, liberteez, and laudable custumes foresaide, to the honoure and comen wele of this worshipfull towne, and all thenhabitaunts of the same.

HIT is so, that there hath been alweyes Maires in this worshipfull Fo. $153 b$. toune seth the Conquest, and byfore, whiche,-after that the castell of Bristowe was first founded and bylde by that noble erle of Glouc', Rob ${ }^{t}$ Consul, son bastarde vnto king Herry Beauclerk, the yongest son of William Conquerour,--the Mayres in that tyme used yerely on Mighelmas daye to feche and take theire othe and charge at the castell yate of Bristowe, of the constable of the saide Castell. And the same vse contynued vnto the comyng of that blissid prince king Edwarde the thirdde, whiche, among othir fraunchisez of his gode grace grauntid, by his honourable chartres exemptid the saide maires, and discontynewed theym, to feche their saide charges at the castell yate of the foresaide Constable, but ordeigned by the same fro that tyme sethens, every mayre on Mighelmas daie to be chargid, and take his othe of his next predecessour in the Guyldehall of Bristowe, before all the Cominaltee there. For the whiche it hathe alweyes sethen be usid yerely, that the iiij. Sergeauntes, waytyng on the mayre, shall vpon Seint Giles day, the first daie of the moneth of 
Septembre, warne all the worshipfull men of the Counceill of Bristow to be in theire Counseill Hous, at the Guyldehall of the same, the morowe vpon the daie of thexaltacion of the holy Crosse, Election of the at thellection of their Mayer and othir officers for the yere following; Mayor on 15 September. every man on peyne of $x$ li., as it was ordeigned in the tyme of Stephyn le Spycer, being Maire in the xviii $^{\text {th }}$ yere of the reygne of kyng Edward the thirde. And then in their saide Counseill hous sytting, the Maire, the Shiref, and all theire brethern, ffurst the Maire to exhort theym all and euery of them, with a pater noster and an ave, to pray the Holly Goste to be at their seid eleccion. And therevpon the Maire, first, by his reason to name and gyve his voice to som worshipfull man of the seide hows, and after hym the Shiref, and so all the house perusid in the same, euery man to gyve his voice as shall please him; which shal alle be wretyn by the towne clerk, and by the same reporte and present hym that hathe moste voises. Whiche persone so in due fourme electid to be Maire shal rise fro the place he sat in, and come sytt $a$ dextris by the olde maires side. And after all their communications there at that tyme he shall be worshipfully accompanyed, with a certein of the seid hous, home to his place.

Item, after all this doon, the seide persone so electid maire shalle haue his leysour to make his purveyaunce of his worshipfull householde, and the honourable apparailling of his mansion, in as plesaunt and goodly wise as kan be devised, untill the festall daie of Seynt Mighell Tharchangell then next folowyng, whate daie that evere he fall in the yere. The seide new Maire then to come to the Guyldehalle, accompanyd with the Shiref and all his brethern of the Counseill, to feche him at his hows and bring him to the saide hall, in as solempne and honourable wise as he can devise do to his oune worshippe, and to the honour, laude, and preysyng of alle this worshipfull towne. That is to say, yf that he haue be maire byfore thenne, he to come in his habite, that is to seie his Skarlat cloke, furred, with his blak a lyre hode, or tepet of blak felwet, and all tho 
that have be mairez in the same habite and lyverey, clokid. And if he haue not be maire byfore tyme, then he to come withoute eny cloke, in his skarlet goune. And all other that haue be maires, the same wise, sauf there servants shulle bere their clokes after them; and in the seid Guyldehall, solemply stonding at the high deise of the same, after the stynting of the commen bell, ffurst the olde Maire to take his leve of his brethern and of all the comyns ther beyng, hauyng his wordes and speking under this maner of fourme:-

"WorshIPFULL maisters and frendes, it is not owte of your The old remembraunce that this daie xii. moneth, $I$, vnworthy, was sworn to be maire of this honourable Citie for this yere that is passid. And Michaelmas Sirs, if that I haue done, of my negligens and wilfulnes, otherwise Day. then right lawe and good conscience wolde to ony man or woman, I will pray theym come to me, and $I$. shal be redy to make theym amendys in that I have offendid theym, yf my goodes will suffice therto, or ellys I shal aske theym forgevnes in as herty wyse as I can, trusting verilly in God they shal haue no grete causez of ferther complaynts.

"F URThermore, Maisters and ffrendes, $I$ am not sufficient ne can not thanke you of your godenes accordinge to youre due merits, for in you hath bene trewe obedience to kepe the king our alther liege lorde is lawes, and my commaundment in his name, at all tymes. For whiche, where as I am not able ne of power to deserve it vnto you, I pray [vnto]* almighty God rewarde you with [also]* moche joy, prosperite, and peas, as evir had comens and true Cristen people.

"Furthermore, Maisters and ffrends, here is a worshipfulle man, A.B., chosen to be oure Maire for this yere comyng, whiche of his grete wisedom, by goddes grace, shal refourme and amende alle such thinges as I of my sympilnesse haue not duely ne formably executed and fulfilled; and, worshipfull maisters and frends, the holy

* The erased words within brackets [ ] are by a later hand. 
Trinitee blesse you all and kepe you in prosperouse peas and felicite, long to contynewe, and [the holie Gooste]* evir be with you, Amen." $\dagger$

Item, after this done, so standing at the seide high deise of the Yeldehall, byfore all the seide Comyns, the saide olde maire to holde a boke vnto the seide new maire, and the Towne Clerk with his boke to stand vppe, and rede the Maires Othe and his charge concerning his office, vndre this maner of ffourme.

The Oath and charge to the new Mayor.

"Thus here ye, A. B., my predecessoure maire, and all the goodmen of Bristow, that I, R. S., shall be good and true to King Edward the ffourth, Kyng of England, oure alther liege lorde, and to his heirs and his successours, and trewly with all my power I shall saue and kepe this his Toune of Bristow, to hym and to his heires and to his successours. I shall kepe and meyntene the peas of the same toune with all my power. I shall reproue and chastice the misrewlers and mysdoers in the forsaid toune, as lawe and reason wolle, by my power. The fraunchisez and free custumes whiche beth gode in the saide toune I shall meyntene, and all euell custumes and wronges I shall put awey and anyntese, be my power. I shall kepe, meyntene, and defende, the Wydowes and Orphans of

* The words between brackets are added in the margin in the original.

$\dagger$ Fo. $154 b$ of the MS. finishes with this paragraph, and here two leaves have been carefully inserted, on which is written the Mayor's oath in the time of Henry VIII. It recites him as " defendor of the Faithe," \&c., and includes all the clauses of the oath given by Ricart (Edw. IV.) but a clause is added (next before that in support of the house of the Kalendars (a), p. 73) in the words enjoined by sec. 6 of the Act 28 Hen. VIII. c. 10, for "extynguysshing the auctoryte of the Busshop of Rome." In the time of Philip and Mary the oath was again corrected; their names and style are inserted instead of those of Henry, which are crossed out; and the fresh clause as to the bishop of Rome, and the old one as to the Kalendars, are struck out. To complete the history of the oath, fo. $195 b$ contains a copy of the oath as taken (according to a side-note) in 1598, 40 Eliz., which resembles that of Edw. IV. but omits the clauses as to Lollardries, the causes of the church, the kalendars, and as to bye-laws of the City, being the portions marked on pp. 73, 74, between brackets. A new clause of supremacy, under the Act 1 Eliz. c. $1, \S 9$, is added. 
this forseide toune sauely in hir rights, be my power. I shall well and truly serue the king in the office of the Eschetour in pe shire of Bristowe. And I shall do the kinges profite in all thingez that longith to me to done, bi my konnyng and my power. And I shall trewly kepe his rightes which that longeth to the Crowne. I shall not assent to destry ner do no councelement of the kynges rightes, nor of his fraunchises. And where I may know the kynges rights of his Crowne, be it in landes, be it in rentes, or in fraunchises, or in sute3, conceled or withdrawe, I shall do my trew peyn to repele and reforme it, and, yf I may not do it, I shall say to the king or to them that beth of his counseil which I shall be in certeyn* shall sey it to the kyng. I shall trewly, and with right, trete the people of my bailly, and do every man right, as wel to the poer as to the riche, in that that longeth to me to do. And nouther for ghifte, nor for loue, affeccion, promesse, nor for hate, I shall do no man wronge, nor destourbe no mannes right. I shall take no thing wherthurgh the kyng may lese or the kynges right may be destourbed. I shall take myne enquestis in open places, and not in prevy place, and that by endenture after the purport of the Statute made of Eschetours. (I shall do my entier payne and diligence to put awey, cesse, and destruye, all maner heresies and errours, clepid openly lolladries, within my bailly, from tyme to tyme, with all my power. And I shall be assistent to the Ordinaryes and her commissariez of holy chirche, and fauor them and mayntene them, atte alle tymes, in all rightfull causes, when $I$ shall be therto required by the same Ordinaries or be her Comissaries. (a) Also, I shall be helping, supportyng, and fauoringe to the Prioure and his brethern the prestis of the hous of the Kalenders of Bristowe, in all thinges that I may lawfully and honestly do of right, as her verray patron, to the confirmacion and defence of the rentez, londez, and tenementez of the same hous; sauing euery mannes right.) Also I shall holde, kepe, and meyntene all laudable ordinaunce3, whiche

* One or two of the words in this line are inserted, and others are erased.

CAMD. SOC. 
hath be made and used afore this tyme be my predecessours, Maires, Aldermen, Sherifs, and the commen counseille of this toune, vnreuokid and vnrepelid; (and alle that shalle be made after this tyme, be my pouer welle and trewly, vn to the tyme that they be reuokid and repelid by the Maire, Aldermen, and Sherifs, and commen counceille of this same toune which shall be for the tyme.) And I shall do euery man right, as well to the poer as to the riche. And all othir thinges that longith and perteyneth, as well to thoffice of the Maire, as of the Eschetour, trewly do, [as nyghe as God wol give me grace*]. So God me helpe atte halydome [and by this boke*]." And so kysse the boke, \&c.

And after this done, the olde Maire to deliuer vnto the new maire the kynges Swerde, and his hatte, and the casket with the seale of office, the seale of the Statute of the Staple, the seale of the Statute merchant, with other autentike seales encluded in the same. And then the both maires to chaunge their places, then to avoid the halle. And all the hole company to bring home the new Maire to his place, with trompetts and clareners, in as joyful, honourable, and solempne wise as can be devised; and there to leve the new Maire, and then to bring home the olde Maire. ' [ It is ordered at Common Counsell that the new Mayor tenne the old Mayor at his owne house, and goe home with the sword before him afterward. $\dagger$ ]

Item, it hath be usid on the seide Michelmasse day, the moste parte of the Counseill for to dyne with the both maires, that is to sey, a grete parte of theym with the new Maire, and a parte with the olde Maire; in especial all officers to dyne with the olde maire. And after they haue dyned, to assemble all the hole Counseille at the High Crosse, and fro thens the new maire and the olde maire, with alle the hole company, to walke honourably to Seint Mighels churche, and there to offre. And then to retorne to the new Maires hous, there to take cakebrede and wyne. And then, euery man

* The words between square brackets have been inserted. See before, p. 72, note $\dagger$.

$\uparrow$ This is added in the margin in a much later hand. 
taking his leeve of the Maire, and to retray home to their evensong.

Item, it hath be usid, that on the morowe upon Michelmas day, Next day, the the new Maire, the Shiref, and certeyn of their brethern, to resorte ${ }^{\text {officers of the }}$ coration are unto the Counter, and there to call afore theym the Baillyfs, to take their Touneclerk, Styward, and all the Sergeauntz of Bristow, with all the porters of the yatez of the same Toune; and so fro the seide Counter to go to the Yeldehall, there to take their othes after the maner and forme conteyned in the rede boke, of olde tyme by the common counseill of Bristowe made, ordeigned, and to be kept for euer.* And therevpon forthwith one of the Baillifs, by the maires commaundement, to go kepe the markett court.

Item, it hathe be vsid, on the thirde day after Michelmasse day, after alle suche othes geven to the forseid officers, that then the seide Maier to call to hym the most worshipfull of his brethern of the Counseill, to go with hym to the yeldehall, there openly to be redde the Shirefs commyssion, the dedimus potestatem, the wryt of attendaunce; and therupon the Shiref to take his othe, after the

* The "rede booke" here named must mean the volume known as the "Little Red Book," some of the early pages of which contain a number of oaths to be taken by the city officers, written in French in the time of Edw. III. The oath of the Town Clerk is as follows (fo. 18). "Sacramentum clerici eommunis. Ceo oyetz vous Maire et bones gentz qe ieo serrey foyal et loyal a nostre seygnur le Rey et a les maire et commnnaltee de B., et le counseyl del dist nostre seygnur le Rey et de la ville celerey, et loyalment les plez, pledez en la gihald de la diste ville devaunt les distz maire et baillifs par lauys de le Recordour, ${ }^{1}$ en roule entray, et nulle fause querele ne meynteyndrey nautry droyt ne destourberey a moun ascient, et la fraunchise, la pecz, custumes, et ordinaunces qe bones sount garderey et defenderey. Et toutz les briefs, comissiones, remembraunces, et totes altres choses tochanntes la diste commun a lyuerez a moun poayr saluement garderey, et altres choses appendaunts a moun office loyalment fray a moun ascient, sy dieux meyd." The oath of him who seems to have been Clerk to the Counter is on the same page. See after, p. 88.

1 "le Recordour" is written over two words now illegible. 
forme and effect of a Cedule sende fro our Soueraigne lorde the kyng, enclosid within the seid dedimus potestatem, if so be that it be then $y$-come.

And the same tyme, in semblable wise, there to be redde the Maires Commission of the Staple, with the dedimus potestatem, and vpon the same the Maire there to take his othe, after the ffourme and effect of a Cedule enclosid withyn the seide dedimus potestatem $\mathrm{yf}$ it be then $\mathrm{y}$-come. And the ij conestablez like wise.

Item, it hath be vsid, that the Maire the same daie shall kall byfore hym all his Sergeauntez, and to make theym bryng yn their suertees to be bounde with theym vnto the seide maire, euery of them in their seueral obligacion, of $x$ li. or $x \mathbf{x}$ marcs of their good abering and trewe executing of their officez during that yere, as wele in the Staple court as othirwyse, for to make due levey, and truly pay and content almaner of ffynes, issuez, mercementez, condempnaciones, and executiones, at eny tyme had and recovered in the seide Maires Court, vnto the seide Maire and to such personez as the seide recovrees belongeth to of right.

And in semblable wise, the same tyme, to kall byfore theym the Shirefs' Sergeaunt3, and to be bounde in lyke wyse vnto the Baillyfes, for the yer folouyng.

Item, it hath be vsed, on the iiijth daie aftir Mighelmas, the seide newe Maire to let sommen all the chauntry preestis whos composicions are enrolled in the rede boke; that is to seie, Everard le Frenshe his preestis, Richard Spicer his prestis, John Spicers preest, John Stokes prest, Water fframpton is prest, Edmond Blanketts preste, Thomas Halleweyes preeste, John Burtons prest, William Canynges preestes, John Shipwardes preste, and Thomas Rowley is preste, to com before the Maire to the Counter, there to take their othes, truly to obserue their seide composicions; * and theire seide

* A "composition" was a bond or agreement, in these cases establishing a chantry and containing ordinances for its government. (See a very curious "composition" or agreement for the payment of church dues in London in 1457, 
othes to be made vnder this forme, that is to seie, euery of them to ley his lyfte hand on the boke, and his righte hande on his breste, makyng his othe per sancta euangelia and per verba sacerdotis.

Item, it hath be vsid, the said iijth day after Michelmas daie, and The Masters of fro thens forthe, the seide Maire to let somon all the maisters of the crafts are Bakers, Bruers, Bochers, and of all other craftes of the Towne, to the fourth day come byfore hym, and then to go and assemble them att their halles mas. and places accustumed, to thelleccion of their maisters for the yer folowyng; and therupon to bryng theire seide maisters and present them before the Maire, pere to take their othes in the maires

Arnold's Chronicle of London, p. 71.) The "rede boke" appears again to mean the "Little Red Book" before mentioned; in it are many of these "compositions," for the most part in Latin, and thence we learn that the dates of their foundations were:- E. le Franceys, 1350; Richard Spicer, 1377; John Stoke, 1385; Walter Frampton, 49 Edw. III. (1376); Edmund Blanket, 1389. Two others contained in the Little Red Book are those of Richard de Welles, in 1333, and Richard White, in 1334. That of Joan Hallewey (for her husband Thomas) is in English: it may serve as a specimen of the others. (L. R. B. fo. 157.)

“This is the composicioun and ordenaunce of Johanne Hallewey, laat wif of Thomas Hallewey, laat burgeis and marchaunt of the towne of Bristow, maad creat and establisshid for the gode reule of a chaunterie laat foundid bi pe saide Johanne, as executrice of the testament of the saide Thomas, in the chirche of Allehalwis for enermore, as hit apperith in articles herafter, and y-made the vij day of Junij the yerre of the reygne of our soueraygn lord the kynge Herry the sext after the Conquest $\mathrm{xxxj}^{\mathrm{t}}$." The document goes on to appoint a priest to perform chantry services, and gives him a salary and "chambre and mansion" in a new house lately built; the appointment of such priest to be made by the Mayor under seal, the priest to make oath yearly before him to perform his duties in the services. The priest is to find his own "singing breed and wyne." The Mayor is to assist the procurators (churchwardens) of the church in looking after the rents and property of the chantry, and for this trouble certain sums are to be paid to the City Officers. (See the case of Canynge's Chantry, after, p. 79.) The procurators to make account of the property at the same time that they account for the "liflood [income] and other thinges" of the church, in presence of the Vicarie " and the worthiest men for the time being of the saide parisch." Dated 20 Juyn, 31 Hen. VI. (1453). This instrument not only explains the connection of the chantry priests with the mayor, but gives a very interesting glimpse of the management of parish affairs at that date. 
presence, after the form conteyned in the Rede boke.* And therupon the seide maire to commaunde, and see to be doon, that euery of his Sergeauntes duly therafter bryng before hym, of every warde of Bristow, as many gode and wele disposid personez to be swore constables for the yer folowyng, as every warde will of right aske and require, by the discrecion of the saide maire.

Usual procla- Item, it hath be vsid in the seide toune, that the Satirday next mations, \&c. to he made. after the markett court done, the Maire to do to be proclaymed all the articles of the commen proclamacions of all vitaillers, and othir thyngez, of olde tymes ordeigned, by the common counseill of Bristowe, to be proclaimed within the same toune. And therupon the seide Maire to procede to all his courtes, of almaner accions personely bifore the Maire and Shiref, or bifore the Bailyfs for the tyme beyng to be holde. And therupon to sett and proclayme the daies of Assise and pleas of land, vndre this forme, that almaner of pleyntifs and defendaunts, demaundants and tenaunts, that haue a do before the Maire and the Shiref of Bristowe, or the Maire and Baillyfs of Bristow, in eny assise or in eny othir plee of lande, that they keep their daie in the Guyldehall of Bristowe.

* In the "Little Red Book" there are entered the Ordinances of divers crafts of the town, and the following extract from one set of these throws some light on the above paragraph. It has no date, but stands between other ordinances of $21 \mathrm{Hen}$. VI. and 35 Hen. VI. and was written about the same time. (L. R. B. fos. 148, 149.) " To worschipful sires, Maier, schireve, and godde folke of the commune counsaile of the towne of Bristow, prayeb mekelich pe goode folke of the craftes of fferours, smythes, cotillers, and lokyers of the said towne," that they will " gracyouselich grawnty to be seyd goode ffolke" certain articles and ordinances following, among which is:-

"And vppon thees ordynaunces and artycles be gode folke of be seid iij craftes preyeb bat fowre maystres mow be chose by be seid craftes everich yere, for to surveye the defawtes of be seid craftes, and $y$-swore to fore the Mayer, trwlych to present to the mayer and to his mynystres of pe seid towne alle the defawtes bat they mow fynde.

"Reseruyng alle tyme to be mayor of Bristow and to be consayle of be towne power to correcte, to pynyssche, amercye, and redresse, as wel be maystres and alle oper persons of the seyd fowre craftes, everych after her deservyng and trespasse, as be case askyth." 
Item, it hath be vsid, that within a moneth aftir Mighelmas day The Law day the Maire, Shiref, and Baillyfs of Bristowe, to holde their lawe day or View of in the Guyldehall, by the Toune clerk of the same Towne, there to call, furst the hole counseill of Bristowe, withoute eny mercemente3, and after that to call all free holders and commen sewters, vpon peyne of their mercementez, and then to call the constables of euery warde. And so to procede to his enquests. And when the seide Toune clerk hath engroced his lawe daye, then within vij or viij daies upon that, the seide Maire, Shiref, and Baillyfs, to holde their The affering fferyng day, and therupon the seide Toune clerk to make vp his day. Stretys vnto the Baillifs, keping a Registre of the same to remayn with the Maire, as of olde tyme it hath be vsid and accustumed.

Item, hit hath be vsed, vpon Al Hallowen day the Maire and the 1st November. Shiref of Bristowe, after dyner, to assemble with all the hole counseill, at the Tolsey, with many othir gentils and worshipfull comeners, such as apperith there at that tyme, and fro thens to go into All Hallowen chirch, there to offre, and fro thens to walke, all in fere, vnto the Maires place, there to haue their ffyres and their drynkyngs with spiced Cakebrede, and sondry wynes; the cuppes merilly seruyng aboute the hous: and then fro thens euery man departing vnto his parish chirch to evensong.

Item, the morowe vpon All Sowlen day, the Maire is vsid to walk 2nd Novemto Redclyff, and the Toune clerk with him; there to sytte in Audite ber. vpon William Canynges $i j$ chauntryes, and the vicorye and the propters* with them. And aftir the seide Audyte is fynesshid, the Towne clerk to entre thaccompte of the same in a boke there, callid Canynges liger, and there the Maire to receyve I noble, the toune clerk xxd., the swerdberer viijd., and the four Sergeauntez of the Maire xvi d. $\dagger$

* So in the original, but evidently au error for Proctors, the contraction of Procurators (or churchwardens). Canynges' Chantries were but a very few years old in Ricart's time ; he founded them in $7 \mathrm{Ed}$. IV. 1467. The principal documents concerning them are contained in the "Great Red Book," fol. 288 to 296.

$\dagger$ See, before, note on p. 77 . 
And fro that day fforth, the Maire, Shiref, and othir officers to go and kepe the generall Obites, holden in the said Toune, as wele in winter as in somer, and to receyve their ffees at the seyde Obytes, as is notid here folowyng in this present Boke, all the seide Obitez and the ffees and rewardes of the same.

23rd Novem-

Item, on Seynt Clementez even, the Maire, Shirif, and their breber. thern, haue vsid to walke to Seynt Clementis chapell within the Berthelmeus : there to hire their evensong, and on the morowe their masse. and to offre there.

24th Novem-

And on Seynt Kateryns even, in semblable wyse, the saide Maire ber. and Shiref and their brethern to walke to Seynt Katheryns Chapell within Temple church, there to hire theire evensong; and from evensong to walke vnto the Kateryn halle, theire to be worshipfully receiued of the wardeyns and brethern of the same; and in the halle theire to have theire fires, and their drynkyngs, with Spysid Cakebrede, and sondry wynes; the cuppes merelly filled aboute the hous. And then to depart, euery man home ; the Maire, Shiref, and the St. Katherine's worshipfull men redy to receyue at theire dores Seynt Kateryns players. players, making them to drynk at their dores, and rewardyng theym for theire playes. And on the morowe Seynt Kateryns day the Maire, Shiref, and theire brethern, to be at the Temple churche, and 25 November. fro thens to walke with the procession aboute the Towne, and retorne to the seide Temple churche, there to hire masse, and offre. And then euery man retray home.

On St. Nicho- Item, on Seynt Nicholas Eve, yn semblable wyse, the Maire, and las day, 6 December, all join in the festival of the Boy-bishop.

Shiref, and their brethern to walke to Seynt Nicholas churche, there to hire theire even-song: and on the morowe to hire theire masse, and offre, and hire the bishop's sermon, and have his blissyng; and after dyner, the seide Maire, Shiref, and theire brethern, to assemble at the maires counter, there waytyng the Bishoppes comming; pleying the meane whiles at Dyce, the towne clerke to fynde theym Dyce, and to have I d. of every Raphill; and when the Bishope is come thedir, his chapell there to synge, and the bishope to geve 
them his blissyng, and then he and all his chapell to be serued there with brede and wyne. And so departe the Maire, Shiref, and theire brethern to hire the bishopes evesonge at Seynt Nicholas chirch forseid.

Item, the morowe vpon Seynt Nicholas day hit hath be vsid the Baillifes of Bristowe to make deliueree of the Towne ray lyvereies vnto all thofficers of the same, in maner and forme folowyng; that is to sey, to the Toune Clerk, xlij. rayes, and as moche pleyne clothe accordyng; and to his clerk, xxxij. rayes, and the playne clothe accordyng. To the Steward, xlij.rayes, and as moche pleyne clothe acordyng; and to his clerk, xxxij. rayes, and the pleyne clothe accordyng. To the Towne Attorney, xlij. rayes, and as moche pleyne clothe accordyng. To the Swerdeberer, xlij. rayes, and asmoche pleyn clothe accordyng. To euery of the Maires Sergeauntez, and of the Shirefis Sergeauntez, xxxvj. rayes, and the pleyne clothe accordyng.

The Paiementes by the Baillyfes of Bristowe yerly to be paide, to the Maire, Shiref, Recorder, and othir officers, ayenst Christmas. All to be paide, except the Pencions to be paide quarterly.*

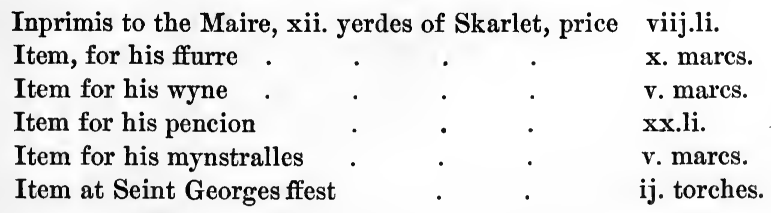

Summa xlj.li. vj.s. viij.d.

Item to the Shiref, x. yerdez Skarlat, price vi.li. xiij.s. iiij.d.

Item for his furre . $\quad . \quad$. $\quad$. v.li.

Item at Seynt Georges fest $\quad$. . . ij. torches.

Summa xj.li. xiij.s. iiij.d.

* This account should be compared with a very curious Account of the Sheriffs of Bristol with the Exchequer, which includes some of these items; a transcript of which is contained in the British Mnseum, Add. MS. 24,785, fos. 10-21. It is fuller than that in Barrett, p. 123. See also the record quoted before, p. 50, note *

CAMD. SOC. 
Item to the Recorder, $\mathbf{x}$ yerdes skarlat, price

Item for his pencion

Item for his furre

Summa xix.li. xiij.s. iiij.d.

Item to the Towne Clerke for his pencion

Item for his furre .

Item for his parchemyn, wax and wyne .

Summa v.li. vj.s. viij.d.

Item to the Stewarde for his pencion

Item for his furre

Item for his paper and parchment

Item for his wyne

Summa iij.li. ix.s. iiij.d.

Item to the Towne Attorney for his pencion

Item for his ffurre

Summa iij.li. vj.s. viij.d.

Item to the Swerdberer for his pencion

Item for his ffurre

Snmma iij.li. vj.s. viij.d.

Item to the preest of Seint George for his pencion

Item for his gowne and a hode

Summa v.li. vj.s. viij.d. vj.li. xiij.s. iiij.d.

x.li.

iij.li.

iiij.li.

vj.s. viij.d.

xx.s.

liij.s. iiij.d.

vj.s. viij.d.

vj.s. viij.d.

ij.s. viij.d.

iij.li.

vj.s. viij.d.

iij.li.

vj.s. viij.d.

viij. mares.

iiij. yerdes brode clothe.

The Mayor Item, hit hath be vsid, the Maire of Bristow anon after mighelmas, must overlook
the Bakers and the assize Bakers of Bristowe, there to vndirstand whate stuff they haue of of bread. whete. And after, whate sise they shall bake, and to assist and counseil theym in theire byeng and barganyng with the Bagers, such as bryngeth whete to towne, as wele in trowys, as otherwyse, by lande and by watir, in kepyng downe of the market. And that the Bakers lak no stuffe, in especiall ayenst the fest of Christmas, and at suche tymes as many straungers resortith to the towne. And the Maire dyuers tymes to ouersee the weyeng of brede, at such seasons as he thynketh necessary and requisite, aftir his discrecion, or vpon compleyntz made vnto hym for the same. And that the Bakers enhaunce not their sises above vj d. at ones, according to the statute, \&c. And whate Baker that breketh the sise, to be punysshed, aftir 
the constitucion of the Towne, as apperith here folowyng in this present boke.*

Item, hit hath be vsid, in semblable wyse, the seid Maire anon The Mayor aftir Mighelmas, to do calle byfore hym in the seide Counseill hous, $\begin{gathered}\text { must overlook } \\ \text { the Brewers }\end{gathered}$ all the Brewers of Bristowe; and yf the case require that Malt be and the Assise skant and dere, then to commen. there with the housholders of Brewers vpon a wise prouision to be made for the reformacion of the same; and to bryng malte to a lower price, and that such price as shall be there sette by the maier vpon malte, that no brewer breke it, upon payne of $\mathrm{xl}$ s., forfeitable to the chambre of the Toune. And the shyftyng daies $\dagger$ of the woke, specially the Wensdaies and Satirdaies, the Maire hath be vsid to walke in the morenynges to the Brewers howses, to oversee theym in seruyng of theire ale to the pouere commens of the toune, and that they have theire trewe mesurez; and his Alekonner with hym, to taste and vndirstand that the ale be gode, able, and sety, keping their sise, or to be punysshed for the same, aftir the constitucion of the Toune, as apperith folowyng in this present boke.*

Item, it hath be vsid, the maire this quarter specially to oversee This winter the sale of wodde commyng to the bakke, and to the key, and to quarter the sett price vpon the same by his wyse discrecion; and that no wodde regulate the there be solde vntil the price be sett vpon it by the saide maire, ne price of wood. none to be deliuered there byfore ne aftir a certein houre by the seide Maire lymitted. And that all grete wodde, callid Berkley wodde, be dischargid at the key beyond the Towre there, and all smalwodde to be dischargid at the Bak. Prouydid alweys that the woddesillers leve not the bak all destitute and bare of wodde, ne soffir not the halyers to hale it all awey, but that they leve resonable stuff upon the bak fro spryng to spryng, to serue the pouere people

* See after, p. 94.

$\dagger$ An ordinance temp. Hen. VIII. says that the Aleconner "shall every shifting day in the year boldly go into the houses of the common brewers, before their shifting of every of their ale, and there shall taste the same, \&c." 
of penyworthes and halfpeny worthez in the neep sesons, vpon peyn of punysshyng, as wele the seid woddesillers, as the seid halyers, by the discrecion of the seid maire.

The standard measure for coal.

Item, that all maner of colyers that bryngeth colys to towne for to sille, smale or grete, that they bryng their sakkes of juste mesure, according to the standard, for the which the maire is vsed this quarter to commaunde the standard mesurez to be sett in diuers places of this Toune, as at the High Crosse, the Brigge corner, and $\checkmark \quad$ Stallage Crosse, so that every sak be tryed and provid to be and holde a carnok,* and the ij. sakkes to holde a quarter, whatsoevir the price be, vpon peyne of brennyng of the sakkes, and parte of the colys, and a parte to be distributed to pore folkes of the Almes howses.

The Mayorand Item, it hath be vsid, the Maire and Shiref of Bristowe to kepe Sheriff hold a Court every week day. theire due residence $\dagger$ at the Counter euery fferyall day, aswele byfore none as afternone, except the Saterdaies afternone and othir festyual evis afternone, and to be there at viij. at the clok and sitte untill $x j$., and atte ij. afternone, sittyng untill v., for to hyre compleyntes and varyaunces betwene parties and parties, and to discerne and determyn

* A carnok or crannock held four bushels. From a comparison of Harl. MS. 368, fo. 11, with this ordinance it appears that these must have been true coals, in the modern sense. A Petition (without date, but seems to be of the time of James I.) was made by the Mayor and Commonalty of Bristol to the Privy Council, in which it is stated that the poor "doe use only to burne Stone Coale alias Sea Coale in their howses, which Coale they have had from Kinges Woodde and other places," paying not above $3 \frac{1}{2} d$. per bushel, which was a great benefit as wood was very scarce. (Compare the last ordinance above, as to wood.) Complaint is made that one Arthur Player has engrossed "all the Coale Pyttes," wherehy the price is enhanced, and "hath cutte and diminished the sackes of such as vse to bring Coale to the said Cytie." In 1606 an ordinance was made by the City as to the sale and measure of "stone coal." MS. Brit. Mus. Egerton, 2044, f. 12. Before this time, in 1566, a letter to Sir Wm. Cecil says that "at Bristoll all manner of fewell is good cheap, a myne of sea cole being allso within iiijor myle of Brystoll." State Papers, Domestic, vol. 40, f. 17.

$\dagger$ " Residence to be kept bi the Maire at the Tolsill." Side note in MS. See note before, p. 53. 
the same after theire discrecion, and, by thaduyce of theire brethern there beyng with them, to sett parties in rest and ease by theire advertysement, compromesse, or otherwise; ynless then it so requyre that they must remit theym to the lawe, as they can be aduysed by the Recorder if he be present, or by the Town clerk in his absence: which Audience kepyng by the Maire and Shiref in the saide Counter, is the grettyst preseruacion of peas and gode, rule to be hadde within the toune and shire of Bristowe that can be ymagened, for yf it wer anywhiles discontynewid, there wolde right sone growe grete inconvenyence amongst thenhabitauntez of the same, which God forbede.

Item, the Maire and Shiref of Bristowe shall, by vsage this quarter and ceason byfore Christmas, kepe theire Aduent sermondes; that is to sey the furst sonday of Aduent, which fallith alweies the sonday next after Seynt Lyues day the bisshop in Nouembre, at which furst sonday the seide Maire and Shiref, with theire brethern, shall walke to the ffrere Prechours, and there hyre theire Sermonde. And the next Sonday therupon, they shall hire sermonde at the ffrere menors, and the thirde Sonday at the ffrere Prechours. And the fourthe and laste Sonday of Aduent at the frere menors. And there to make an end of Aduent Sermondes.

Item, the Maire of Bristowe shal, by vsage this quarter the next Proclamacion markett day byfore Christmas daie, or ellis on Christmas eve, do for peace make open proclamacion for gode rule and governaunce to be hadde Christmas and kept within the saide town, duryng the holy dayes, under this holidays, and maner of fforme:-

"The Maire and the Shiref chargen and commanden, on the the reign of the Lord of Misrule.

kyng our souuerain lordis behalf, that no maner of personne, of whate degree or condicion that they be of, at no tyme this Christmas goo a mommyng with cloce visaged, nor go aftir curfew rong at St. Nicholas, withoute lighte in theire handes, that is to sey skonce light, lantern light, candel light, or torche light; and that they goo 
in no wyse with wepyn defenssibly araied, wherbye the kinges peas may in eny maner wise be broken or hurt, and that vpon peyn of prysonment, and makyng ffyne and raunson to the kyng." *

A general pro- Item, an other proclamacion for conseruacion of the kynges

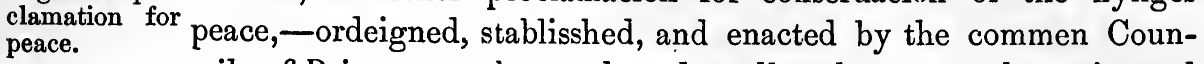
seile of Bristowe, to be proclamed at all such tyme as the maire and the Shiref for the tyme beeng shall thinke it necessarie; in especial ayenst gode tydes and feestys, as Christmas, -is to be proclaimed in this wyse:-

"The Maire and the Shiref chargen and commaunden, on the kyng our souverain lordes behalf, that no maner of persone or persones go nor walke within this town of Bristowe, with no Glaythes, speerys, longe swerdys, longe daggers, custils, nother Baszelardes, by nyght nor by day, whereby the kinges peace in any maner wyse may be trobbelid, broken, or offendid, but the personnes that bith officers and othir that commen ridyng into the towne, or goyng oute of the Towne; and that vppon peyn of fforfeiture of thaire weepyns, and theire bodyes to prison. To the accomplysshment of the whiche premysses, the Maire, Shiref, and commen counseile of Bristowe forseid, chargen and commaunden all maner burgeyses of this Towne of Bristowe, on the kyng our soueraigne lord is behalfe, to be aydyng, helpyng, supportyng, menteyning, and ffavouryng, to the execution of the same, and that vppon peyn that may or woll befall thereuppon."

* This proclamation was directed against the abuse of the popular sports which obtained during the festivities of Christmas. The Lord of Misrule, "beginning his rale at All-hallow eve, continued the same till the morrow after the Feast of the Purification, commonly called Candlemas Day, in which space there were fine and subtle disguisings, masks, and mummeries "' (Strype's Stow's Survey, Bk. i. p. 252); and mumming with visors, "cloce visaged," was especially a Christmas custom; sometimes turned to evil purposes. See Brand's Pop. Antiquities, i. p. 356. Similar proclamations were made in other towns on like occasions, e.g. York and Coventry. Hone's Ancient Mysteries, p. 211; T. Sharp's Coventry Mysteries, p. 169, note: 


\section{SACRAMENTUM Recordatoris.*}

This here you Mr. Maiour, Mr. Aldermen, Mr. Sheryves, and the rest here present, that I, Thomas Hannam, Recorder elect of this City of Bristoll, shall and will be from henceforth faythfull and true vnto our Soueraigne Ladie the Quenes Maiestie, her heires and successors, and shall and will be beneficiall and true to the Maiour and Cominalty of this City, duringe the tyme of my said office, in what may appertaine therevnto to my power, and geve therevnto the best councell I can, without any partyalty, love, favour or hate. I shall and will, duringe the said tyme, truely and indifferently geve myne advise to the vttermost of my skyll, in all manner of pleas or causes to be holden in any of the Quenes Courtes of Recorde within the said Citye, wherevnto I shalbe for that purpose made privie. I shall mayntaine no vntrue querelle in any of the said Courtes, nor staye the lawfull proceedinge thereof without cause reasonable. I shall duringe the said tyme of myne office do myne endevour to kepe and defende the laudable customes, fraunchises and liberties of and within this Citye and the Quenes peace within the same to my power, and shall to my power stande holy to the Maiour and Comynalty of this Citye in all manner of matters and causes concerninge the same, wherein myne advise shalbe nedefull and required duringe the said tyme of myne office; and shall not be of counssell in any matter or cause against the Maiour and Comynalty of this Citye during the said tyme, ne shall wittingly be of counsell or pleade or deale parcyally in any manner of wyse, for or with any person of the Common Counssell of this City against any other of the same counssell during the same tyme. I shall from heneefoorth truely and secretly holde and kepe the counssell of this Citye and all other thinges belonginge to my said office of Recorder. I shall and will well and truly perfourme and keepe to my power and connynge as

* This and the following Oath occupy fo. 165. Thomas Hannam was chosen Recorder in 1585 . 
nere as God shall geve me grace. So helpe me God and the holly contents of this booke.

\section{Sacramentum Communis Clerici.*}

You shalbe faithefull and true to our Soveraigne Ladye Queene Elizabethe, hir heyres and successors, and to the Mayour and Cominaltye of the Cytie of Bristoll and their successors, and well and truelye you shall vse and exercise the office of Town Clarke of the sayde Citie of Bristoll, and shall geve good and holsome counsell to the Mayor and Aldermen of the sayd Citie, accordinge to your skill and knowlege, in all matters when you shalbe therevnto required concerninge the sayd Cytie. You shall geve good advise and counsell (accordinge to your skill and knowledge) in all accions and pleas dependinge, as well in the Courte houlden before the Mayor and Aldermen in the Guildhall of Bristoll, as alsoe in the Court there houlden before the Mayor and Constables of the Staple. You shall maynteyne noe untrue quarrells in any of the sayd Courtes. The libertyes and custumes of the sayd Citye which be good and laudable you shall kepe and mayntaine to your power, and shall well and honestly behaue and demeane yourselfe in youre saide office duringe such tyme as you shall contynewe therein. And all other thinges appertayninge to your said office you shall well and trulye doe and performe, accordynge to your skill and knowledge, as neer as God shall geve you grace. Soe helpe you God.

\section{[The Sheriffs' OATH.] $\dagger$}

Ye shall well and truelye serve the Queenes Maiestie in the offyce of the Sheryves of the Cyty and Countye of Bristoll, and doe the

* Compare the oath, temp. Edw. III., before, p. 75.

+ Fos. $195 b-197 b$ are occupied by the Mayor's Oath, temp. Eliz., already referred to (see before, p. 72 note $\dagger$ ), and the Sheriff's and the Bailiff's Oaths here given. The two last are written in a hand of about 1598. 
Queenes profyttes in all things the belongeth to you to doe by virtue of youre offyce as farre fourthe as you can or may. Ye shall trulie keepe and maynteyne the Queenes rights in all that belongeth to the Crowne, to your power. Ye shall not consent to the decresinge, dyminishinge, or concealment of the Queenes rights or of her fraunchesses, and whensoever ye shall have knowledge that the Queenes rights of the Crowne be concealed or withdrawen, be yt in landes, rentes, franchises, or suytes, or any other thinges, ye shall doe your best endevour to make them to be restored to the Queenes Maiestie agayne. And yf you may not doe yt of yourself, ye shall certyfye her highnes thereof, or one of her Counsell that will shewe yt unto her Maiestie. Ye shall not respitt the Queenes debts for any gifte or favour where ye may receyve them without great grevans of the debtors. Ye shall truly and rightfully entreat the people of your shryvewyke, and doe right as well to the poore as to the riche, in all that belongeth to your offyce. Ye shall doe noe wronge to any man for any gyft, favour, promise, hate, or reward. Ye shall disturbe noe mans right. Ye shall trulye acquyte at the Exchequier all them of whom ye shall anythinge resceyve of the Queenes debtts. Ye shall nothinge take whereby the Queene may lose or whereby the right may be disturbed, letted, or the Queenes debts delayed. Ye shall truly retorne, and serve all the Queenes wrytts soe far fourth as yt shalbe in your skill and knowledge. Ye shall receyve noe wrytt vnsealed, or any sealed under the seale of any justice savenge the Justice of Oyer or Justice assigned in the same County where you are Sheryffes. Ye shalbe dwellinge in your proper persons within your shryffewyke, and the same you shall not let to farme to any man. Ye shall trulye sett and recover reasonable and due yssues of them that be within your Shryvewyke aftir their state and behavyour. And moreover in eschewinge of manslaughter, robberyes and other manyfoulde grevous offences that be don daylye,namely by them that name themselves Souldyers and be vagarants, which contynually encrece and multyply in number, soe that her

CAMD. SOC. 
maiesties subiects cannot safely ryde or goe abowt their buyssynes, to their intollerable hurte and hinderaunce,-ye shall truly and effectually, with all your dylygence, execute the statutes whereof you shall have knowledge concerninge vagarants and idle persons. These and all other things that belongeth to your said offyce ye shall trulie keepe and doe to your power, \&c.

\section{['The Bailiffs' OATh.]}

You shalbe faytheful and trewe unto our soverayne Ladye the Queenes Maiestie, her heyres and successors, and truly shall doe the Queenes Maiesties profittses for this yere to come, in all thinges touching the Baylywick and fraunchisses of Bristoll, and the Queenes Maiesties peace to your power ye shall truly keepe. And noe fellon, traytor nor misgoverned person, againste the Queens Maiesties lawes shall support or mayntayne in any cause whatsoever. The Queenes Maiesties rights appertayninge to her Crowne trewly and faithefully ye shall kepe and defende, and her Highnes people of this Cytic and countye ye shall rightfully entreate ; and equall righte ye shall doe to every person, as well to the poore as to the riche, in all thinges apperteyninge to your office of Baylliwicke : and the frauncheyes and libertyes and free custumes of this Cytie, truely and faythefully ye shall keepe and mayntayne to your power : and these and all other thinges which appertayne unto your seyd office of Baylliwicke, you and eyther of you shall well and truly doe, execute and performe, accordinge to your power, skill, and knowledge, as neere as God will geve you grace. Soe helpe you God, \&c.

\section{QQ $u$ intum 羽rincipale.*}

[The intent of this Part is seen in the Preface to it, before p. 5, but it is not carried out as fully as it might have been, no references being actually made to any "bokes or levis," not even to the Charters of Henry III. It principally consists of the Charter of Confirmation of 20 Dec., $47 \mathrm{Edw}$. III. (1374), a long document, which recites and

* There is no title to this Part in the original. 
includes four others, all made in the same year:* namely, the Charter 8 Aug. 47 Edw. III., which made Bristol into a County, and gave other privileges (Seyer's Charters of Bristol, 1812, No. 12); and the Exemplification of the Perambulation of the Bounds of the County so made, Oct. 30, $47 \mathrm{Edw}$. III. (Seyer, No. 15); which last itself recites the Letters Patent of 1 September, directing the perambulation to be made (Seyer, No. 13), and the record of the Perambulation, made on 30 September, in the same year (Seyer, No. 14). All this occupies fos. 211 $a$ to $224 a$, and is in Ricart's own hand, the front page having a floral illuminated border round it with a handsome initial letter. In copying the Charter, however, Ricart has omitted the first two clauses ("Edwardus dei, \&c." and "Inspeximus,") and has begun with the third clause ("Edwardus dei," \&c.) which is in fact the first recital. This omission another hand has supplied on the blank page opposite (fo. 210b), apparently from an Inspeximus of Edw. IV., as it adds one more clause in which Edward is spoken of as "nuper Rex."

After this follows, on a single page, a table of the clanses of the Charter of John, (about A.D. 1188, Seyer, No. 3), but without any heading or title; it is copied exactly (except that the numbers to the clauses are left out) from fo. $11 b$ of the " Little Red Book," where it is headed, "In prima carta tot continentur libertates," and is there followed by similar tables for the "second" and "third" charters, which are not given by Ricart. On fo. 226 is the copy of Letters Patent referred to in the note $\ddagger$ before, p. 55 .

The whole of these Charters having been printed by Seyer, the table of John's Charter is alone given here.

\section{IN PRIMA CARTA TOT CONTINENTUR LIBERTATES. $†$}

Quod nullus Burgensis Bristolliæ placitet extra muros villæ.

Quod sint quieti de murdro.

Quod nullus Burgensis faciat duellum.

Quod senescallus Regis non capiant Hospitium.

Quod sint quieti de Teloneo, lestagio, passagio, pontagio.

Quod misericordia adjudicetur secundum legem hundredi.

Quod hundred semel teneatur in septimana.

Quod nullus Burgensis possit causari per meskeninges.

Quod habeant terras et tenuras suas, et vadimonia et debita sua.

Quod de terris et tenuris infra villam rectum teneatur secundum consuetudinem villæ.

- See the Petition in Parliament on which this Charter was made, Rolls of Parl. vol. ii. p. 320 , No. xix.

† Title from the "Little Red Book." 
Quod de debitis ibidem acomodatis et vadimonijs factis placitent secundum consuetudinem villæ.

Quod nullus capiat de Theloneum de Burgensibus.

Quod nullus extraneus emat de alio extraneo.

Quod nullus extraneus habeat tabernam nec vendat pannos ad decisionem.

Quod nullus extraneus moretur nisi pro xl. dies.

Quod nullus Burgensis namietur vel distringatur pro alieno debito.

Quod possint maritare se filios [suos]* et filias et viduas.

Quod nullus dominorum suorum habeat custodiam eorundem.

Quod nulla recognicio fiat ibidem.

Quod nullus capiat Tynam.

Quod possint molere blada.

Quod habeant rationabiles Gildas.

Quod nullus cogatur replegiare.

Quod teneant omnes terras et tenuras suas, infra muros et extra, in liberum burgagium per servicium landgabeli.

Quod possint ædificare super ripam et alibi. Quod possint ædificare placeas vacuas ad voluntatem corum.

\section{Sextum et ultimum ßjrincipale. $†$}

[The Sixth Part, which occupies 40 closely written leaves, for the most part in Ricart's own hand, is in ten (unnumbered) sections, the headings or titles to eight of which are written in red ink, in the same style as in the earlier portion of the volume. Several of the initials are ornamental letters, and spaces are left for others that have not been filled up.

Of these sections, nine out of the ten are already in print; they are contained in different parts of the Liber Albus of London, $\neq$ in many cases word for word, though here and there, besides a few obvious errors of the copyist, are differences in spelling, grammar, and occasionally in wording, which give interesting variations of reading. They have not however seemed of sufficient importance to justify the reprint of those parts here; all that has been done therefore is to give the titles and

* "Little Red Book."

$\uparrow$ No title in the original.

$\ddagger$ Edited by H. T. Riley, 1859, for the Rolls' Series of Chronicles. 
to indicate the pages of the Liber Albus or otherwise where they may be found. But of the remaining section, which stands fifth among the rest ([5], p. 94), none, with the exception of a few sentences, is found in either the Liber Albus or Liber Custumarum of London, though Parts III. and IV. of the former contain many portions touching on some of the same subjects: much of it being of great interest it is here given entire. It bears evident marks of being, as Ricart says, "wretin oute of a boke," for not only is there no direct reference to Bristol, but several parts" which have special application to London only have been copied with the rest. Such are the passages relating to the Thames, the King's coronation, the payments from foreign merchants, \&c.; donbtless he may have thonght that these too would not be useless as "grete presidents" for the City of Bristol. This section ends rather abruptly with the ordinance against roofing with straw, \&c.; the explanation of which probably is that this seemed a convenient place to introduce the Building Assize of Fitz Elwyn, made in 1189, which though much older than that ordinance (see after, p. 113), was still of such anthority as to be included by Carpenter when only fifty years before he compiled the Liber Albus of London.]

Forasmoche as at all tymes this worshipfull toune of Bristowe Fo. 282. hath take a grete president of the noble Citee of Londone in excerciseing theire laudable customes, it is therfore requisite and necessarie vnto the hedde officers of the saide Towne of Bristow to know and vnderstonde the auncient vsages of the saide Citee of Londone. Wherof a grete parte foloweth hereaftir, wretin oute of a boke that was maistir Henry Daarcy,* sometyme recorder of the saide Citee in kinge Edward the thirdes daies.

\section{Constitutiones Civitatis Londonit.}

\section{[1] Modus procedendi in placitis terre in Hustingo LONDONII.}

[Fos. $282 a$ to $283 b$. Liber Albus, pp. 181-184.]†

"The words "Henry Daarcy" are written upon an erasure, in the same hand as the rest, however. See before, p. 6 .

$\dagger$ The subject-titles to paragraphs which occur very frequently in the Liber Albus, have been omitted by Ricart throughout. 
[2] De Hustingis tenendi de communibus placítis in LONDONIO.

[Fos. $283 b$ to 286a. Liber Albus, p. 184, "En Hustenges des Comunes Plees," to p. 190, end of " De Aldermannis."]

[3] De Assisis Mortis antecessoris in Londonio.

[Fos. 286b, 287a. Liber Albus, pp. 197, 198.]

[4] De Assisis Nove DISSEISINA vocatis FRESHForee IN LONDONIO.

[Fos. $287 a$ to $288 a$. Liber Albus, p. 195, down to the word "pees" in the last line on p. 196.]

[5] De Curia Maioris Londonil et custumis civitatis EJUSDEM ET DIVERSIS CASIBUS TERMINABILIBUS IN EADEM CURIA.

[Fos. $288 a$ to $297 b$. Printed below.]

[6] [Henry Fitz Elwyn's Building assize.

No title. Fos. $297 b$ to $301 b$. Liber de Antiquis Legibus (Camd. Soc. 1846), pp. 206-211. Also in Liber Albus, pp. 319-332, end of first paragraph. The copy which Ricart followed resembled that in the Liber Albus more than that in the Liber de Antiquis Legibus; his version contains several of the passages and words (though not the last two clauses, see $L i b . A l b .331$ note,) wanting in the latter.]

\section{[7] Articuli inquirendi in curia vocata Wardemotis} IN LoNDONIO.

[Fos. $301 b$ to 303a. Liber Albus, p. 332, from "De Pace" to end of p. 336. It is there printed without the above heading.]

[8] Presentationes de Wardemotis.

[Fos. $303 a$ to $304 a$. Liber Albus, pp. 337, 338.]

[9] Ceux sount lez Articles, aunciens Vsages de assise DE PAYNe ET DE SERUOISE ET DAUTRE VITAILle, ET DE PLUsours mestiers de La Citee de Loundrez, que devient 
Chescun an apres la feste de Seint Michell' estre proClamiez et CREez en le Citee.

[Fos. 304a to 311b. Liber Albus, p. 260 to end of first paragraph on p. 280. Fo. 311b, Lib. Alb. p. 364, "Monstratum" to "habeatur." Fo. 312a, Lib. Alb., last two paragraphs on p. 494.]

\section{[10] De Curia Vicecomitis.}

[No title in MS., but a side-note says " de cur' vic"." Fos. $312 b$ to 322 . Liber Albus, from the top of p. 199 to end of first paragraph on p. 223, the portion contained in p. 222 and the first paragraph on p. 223 being in Ricart's version inserted between the paragraphs which stand the two last on p. 215.]

De Curia Maroris Londonit ex custumis Civitatis ejus- Fo. 288a. DEM ET DIUERSIS CASIBUS TERMINABILIS IN EADEM CURIA.

La Court del Maire est tenuz, par custume de la Cite, devaunt le Maire et Aldermans que sount pur le temps en la Chambre del Guihalle, ou en Hustyng, et ceo de ioure en joure a loure volunte; et la sount tretes, termines, et discusses, lez pleez et matiers touchaunts Orphanyns, apprenticialtees, et autres bosoignes de mesme la Citee ; et illoeques sont redressez et correctes les defautez et mesprisouns de ceux qe fount encountre lez customes et ordinaunces de la Citee, sibien al suyt dez parties come par enquest doffice, et en autre maner par suggestioun, solonc ceo que les cases demaundent. Et la vsent de justefier et de treter et ordeigner pur gouernaille de la Citee, et pur sustenaunce de la peas notre Seignir le Roy, et autres points necessaries de la dite Citee, et pur profite de ceux que repairent a mesme le Citee, par loure discrecioun et solonc ceo que le temps demaunde. Item les Officers et ministres de la dite officers Citee trouez en defaute sount iustifiablez devaunt mesmes les Maire ${ }_{\text {droffez }}^{\text {ef en }}$. et Aldermans, sibien al suyte dez parties par proces fait come en autre manere, solonc le discrecioun des dites Maire et Aldermans. Item lez ditz Maire et Aldermans usent illoges de tenire et terminer Accions plees de dette et autres acciouns personels qiconqes, par bille, personalx sibien parentre marchaunts et marchaunts par ley marchaunde, come marchande. 
De prendre recognisauncez.

Statute de Smethefielde.

Assise de Noesances.

De faire ordenauncez.

Pur fauxes nouells. parentre autres qe se pleindre voillent par processe fait devers les parties. Item, les Maire et Aldermans, ou le Maire et Chamberlayn del dite Citee prenont devaunt eux en la dite chambre reconusaunces de dette de touz ceux qe faire lez voillent, et de quiconqes sommes. Et si le joure de paiement soit encurru, a donqs celuy a qi la reconusaunce est fait hors de cest recorde auera execucioun de touts les bienz le dettour, et de la moite de touts cez tenements deinz la dite Citee par extente et pris come a le comune ley. Item plees de dette solonc lordinaunce appelle lestatut de Smethefield sount terminables soulement devaunt lez Maire et Aldermans, solonc ceo qe est plus pleinement contenuz en lordinance ent fait.*

Item, les Assisez de Noesances sount terminablez par bille devaunt le Maire et Aldermans, et quel bille serra servy par lez Viscounts et les parties serount somonz le mersqedy encountre le Venderdy, et adonqes le Maire et Aldermans deynent proceder en plee; solonc ceo qe est contenuz en l'ordenaunce dassise de noesance en la dite Citee.

Item, lez Maire et Aldermans ount tout temps usee de faire Ordinaunces penales sur vitaillez et pur auter gouernaille de la Citee et de la peas, solonc lour discreccioun et advys; et mesmes les ordinaunces proclaimer deinz la dite Citee ouertement, pur estre tenuz et gardez en nomme de nostre seignur le Roy, et de la Citee, sur peyn ent ordeigne; et mesmes les peynes lever de touts ceux qe fount encountre les ordinaunces susdits.

Item, lez Maire et Aldermans ount tout temps vsee de fáire venire devaunt eux lez malefesours qe ount este pris et arrestuz deinz la dite Citee pur mensonges et fauxes nouells ymagines en distourbaunce de la peace, fesours et conterfactours de falx sealx et faux chartres, et pur autres disceits notories; et ceux qils ount troues coupables de tielx malueystees, par conusaunce dez parties ou par enquestes en pris, ount punys par juwys del pilorie, ou auterment

* See Lib. Alb. pp. 233, 475. 
chasties par emprisonement solonc loure desert, et solonc resonable discreccioun des ditz Maire et Aldermans.

Item, lez Maire et Aldermans poent par vsage de la dite Citee chaunger proces, et abbregier delaies en acciouns personelx, sibien devaunt eux mesmes come en courtes dez Viscounts, et de faire nouels ordinauncez touchants tiel plee personelx. Les queux ordinaunces ils entendont estre resonablez et profitablez al people.

Item, fait assauoir qe tout la Cite de Loundres est tenuz de notre De testaSeigneur le Roy en franc burgage, et saunz mesne. Et touts lez mentes. terres et tenements, rents et seruicez, deinz la dite Citee et lez suburbez dicelle, sibien en revercioun come en demesne, sount, devisablez par vsage de la dite Citee issint qe hommes et femmes, par vsage de la dite Citee et suburbes dicelle, a qi qils vorront et de quel estate qilz voudront. Et poent auxi deuisere nouel rent a prendre de mesmez loure tenements, en manere come meulx loure semblera, par loure testaments et par loure darrein voluntie; et ceux qe sount franc homes de mesme la Citee poient deuiser lour tenements a mortmayne, come appiert par la chartre du Roy ent fait. Item, celuy qe tient tenements joyntements* ouesque autres poet deuiser ceo qe a luy affiert saunz auter seueraunce faire: mais enfaunts deinz age ne poent my faire devys, ne lez femmes couerts ne poient my deuiser lour tenements par licence de loure barouns nen auter maner durant la couerture. Item, le baroun ne poet my deuiser cez tenements a sa femme de pluis haute astate qe a terme de vie la femme, ne la femme ne poet claymer auter estate sur peyne de perdere lentiere. Ne le baroun ne poet my deviser lez tenements de droit de sa femme, ne lez tenements queux le baroun et sa femme ount joyntement purchaces ; mais si le baroun et sa femme eient tenements jointement a eux et a lez heires le baroun, mesme la baroun poet deuiser la revercioun. Et touts lez testaments par queux ascuns tenements sount Denroller les deuises poent estre enrolles en hustyng de Recorde, al pur suyte de testaments. chescun qe poet prendre auauntage par mesmes les testaments. 
The enroll- Et lez testamentz qe deyuent estre enrollez serrount emportes ment of Wills in full Hustings.

Rerersions devisez. ou faits venire devaunt la Maire et Aldermans en pleyn Hustyng, et la serra le dit testament proclaimes par le seriaunt, et illeoqes prouez par deux prodeshommes bien conuz, lez queux serrount sermentis et examinez seueralments de touz lez circumstances del dit testament, et de lestate le testatoure, et de soun seale. Et si lez prouez soient troves bones, loialx, et accordaunts, donqes serra le dit testament enrolle en mesme le Hustyng de recorde, et serra paie la fee pur lenrollement. Et nulle testament nuncupatif nauter testament poet estre enrolle de recorde sinon qe la sealx del testament soit mys à mesme le testament. Mais lez Testaments qe poent estre troves bones et loialx sount effectuelle, coment qils ne soient my enrolles ne de recorde. Item, lez testaments deinz la dite Citee deyuent, par custome de mesme la dite Citee, estre aiuggez effectuelle et execute, eient regarde a lez volunteez dez testatours, coment qe lez paroles de tieux testaments soient defectifs ou nient, accordaunts a la comune ley.

[Item, ${ }^{*}$ lou reversiouns ou rent soient deuisez par testaments enrollez de recorde en hustyng, mesme les reversiouns et rents passent mayntenaunt apres la mort le Testatour, issint qe ceux as queux tieux sount deuisez poent distreindre pur le rent et faire avowery; et ceux en reversioun poient suyer brief de Wast a loure voluntee, saunz autre accordements dez tenaunts, et poent pleder par mesmes lez enrollements si meistir soit, coment qils neient my lez ditz testaments en poigne. Ft mesme le custome tient luy dez chartres, endenteurs, et autres escripts enrollez en Hustinge de recorde. Et tieulx enrollementz ount este usee de tout temps, issint qe lez testamentz soient proclaimez et provez en pleyn Hustyng comme devaunt

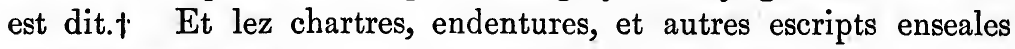

* This passage between the brackets is found in Liber Albus, p. 180, where however it seems to have been inserted by a later hand than that of the compiler of that work.

+ See the last paragraph, which must be the unknown passage referred to in note 2,p. 180, of Liber Albus. 
poient estre acceptes, et lez conusaunces et confessiouns dez femmes ent estre resceux devaunt le Maire et un Alderman, ou devaunt le Recordoure et un Alderman, ou devaunt deux Aldermans pur necessitee, sibien hors de Court come de deinz, issint qe mesmes lez Chartres, endentures, et autres escriptes issint conus, soient en apres entres en Rolle en ascun des Hustynges, et lez feez ent paies, comme le maner est.] Item, la ou homme ad devisee par son testament en Bent devise. rolle certein rent, apprendre de cez tenements deinz la dite Citee, saunz clause de distresse, uncore par vsage de la Citee, celuy a qi le devise est fait poet distreindre et avower le pris, si le rent soit aderere. Et en mesme la maner serra fait de toutz aunciens rents appelles quites rents deinz mesme la Citee.

Item, les Maire et Aldermans qe sount pur le temps, par custome de mesme la Citee, averount lez gardes et mariages de touts Orphanes De garde dez del dit Citee, apres la mort loure auncestres, coment qe mesmes les Orphanyns. auncestres tenoient aillours hors de la Citee dascun auter serra pur qiconqe suite. Et deyvent mesmez lez Maire et Aldermans enquere de touts lez terrez et tenements, biens et chateux, deinz la dite Citec, purtenaunts a tieulx Orphanyns; et mesmes les terres et tenements, biens et chateux, seiser et sauvement garder, al oeps et proffitte de tielx orphanyns, ou auterment coventer mesme lez Orphanyns ensemblement oue loure terres et tenements, bienz et chateux, as autrez loure amys, par sufficient surety trove de recorde en la Chambre de la. Guihalle, de sustener covenablement lez ditz Orphanyns durant loure non age, et loure terrez et tenements reparailler, et loure ditz bienz et chateux sauement gardere, et ent bon et loiall accompte rendre devaunte lez Maire et Aldermans, al proffite de mesmes lez enfaunts quaunt ils viendrent a loure age, ou quaunt ils serrount mys a meister ou maner, par lavys de dits Maire et Aldermans. Et ceo en touts cases, si non qe auterment soit ordeigne et dispose, pur mesmes lez orphanyns ou pur terrez et tenements, bienz et chateux, pur expresses parols contenuz en les testaments de loure auncestres. Et nulle tiel orphanyn doit estre maric saunz 
assent de dits Maire et Aldermans. Et auxint la ou terres ou tenements, bienx et chateux deinz mesme le Citee sount devises a un enfaunt deinz age dun citezein de mesme la Citee, vivant son piere, coment qe tiel enfaunt ne soit my Orphanyn, unqore par usage de dite Citee lez dits terres et tenements, bienz et chateux, serrount en garde dez Maire et Aldermans auxi come dun Orphanyn, pur susti* ner et garder al oeps et proffite du mesme lenfaunt, sinon qe le piere l'enfaunt ou autres de cez amys voude a trover sufficiant suyrty de record de sustiner et garder lez ditz terres et tenements, bienz et chateux, al oeps et proffite du dit enfaunt, et ent rendre bon et loiall accompte, come devaunt est dit.

Les biens la mort serount departies en tres parties.

Citezeins de Loundrez ne serount obedients a nully sinon al Roy.

Proces derrour.
Et fait assauoire, qe la ou un citezein de mesme la Citee ad femme et enfaunts, et devie, touts lez bienz et chauteux du dit mort, apres ces dettes paies, serrount departies en trois parties, dount lune partie demurra a la mort et serra distribute pur sa alme, et lautre partie serra a sa femme, et la tierce partie a cez enfaunts pur owelement entre eux departier. Nient contristeant ascun devys fait a contrarie, et sur ceo sibien la femme come lez enfaunts poient aver loure reco. verire et sute, pur demaunder tieux bienx et chateux, devers lez executors ou autrez occupiours dez ditz bienz et chateux, devaunt mesmez lez Maire et Aldermans, par bille.

Item, par auncien custome de la Citee, ne fuist pas congeable a null estraunger ne forein de vendre vitaille nautre marchaundiz a autre estraunger ne forein deinz mesme la Citee a retaile.

Item, par auncien custome de la Citee de Loundres, les citezeins ne ministrez de mesme la Citee ne deyvent my estre entendaunts a nully maundements ne a nully seale, sinon a lez maundements et al seale nostre Seignur le Roy immediat; ne null ministre nostre Seignur le Roy nautre devoit faire Session ne nulle execucioun deinz la dite Citee, ne deinz la fraunchiz dicel, par terre ne par ewe, sinon soulement par le fraunchise et libertee suisdite.

Item, des juggements donez en Courtes de Viscountes en acciouns personelx ou assises pris devaunt Viscounts et Coroner par custome 
de la Citee,-lez parties vers queux tieux iuggements sount donnes poient suer breve de erroure, direct as Maire et Viscountes, pur reverser lez dits juggements en Hustynges, si les iuggements soit reversables. Et coment qe tieux iuggements soient affermes en Hustynges, unqore mesme la partie purra suyer autre breve derrour, direct as Maire et Viscounts, de faire venire le recorde et proces devaunt Justices assignez a Seint Martyn le Graund, comme ad estre fait avaunt cez houres. Mez si ascun partie, par tiel iuggement donez devaunt lez ditz Viscounts, soit convecte en dette ou en damagez, et pur cell cause commys a la prisone, tanqe il ad fait gree et apres pur sewe breve derrour de reverser le iugements en Hustyng; ou coment qe le Jugement soit afferme en Hustyng et la dite partie voudra suyer auter breve derroure de reverser mesme le iugement devaunt les Justices assignez a Seint Martyn le Graund, comme devaunt est dit; et ne purqant mesme la partie qest issint emprisone ne doit my estre deliveres hors du prisone, par auncien custome de la Citee, pur cause de tiel breve derrour, avaunt ceo qil est trove sufficiant suyrte deinz la dite Citee, ou mys lez devers en mayns de la Courte, pur paier a celuy qe recovery, en cas qe le dite iugement soit afferme en apres. Et en cas qe tiel breve derrour soit suy de reverser ascun jugement donne en Hustyng devaunt Justices assignez a Seint Martyn le Graunde, et commaunde soit par breve de garnire lez parties et de faire venire le recorde et proces devaunt mesmes lez Justicez, donqez serrount lez parties garnis come le ley demaunde, mays nulle recorde purra estre maundez devaunt lez ditz Justices en escript, par custume de la dit Citee. Einz le Maire et Aldermans averount respite de $\mathrm{xl}$ iours, par assignement de mesmes lez iusticez apres loure primere cessioun dez Justices; apres lez xl iours serent lez ditz recorde et proces recordez devaunt mesme les Justicez, par bouche del recordoure del dit Citee ore tenuz. Et dez iugementz donez devaunt le Maire et Aldermans en la Chambre de Guihalle solonc le ley marchaund, soleit nulle errour estre suy.

Item, par auncien custome de la citee, toutz lez Libertees, Privi- 
Les fraun- legis, et autres customes partenants a mesme la Citee, soillent estre chises et liber- recordes par bouche, saunz estre mys ou mandez aillours en escripts. tees de la serrount recordez par bouche, saunz estre maundez passer en nulle enquest. par escript.

Femmez de Londres averount lour frank bank.

Item, les Citezeinz de Loundres, per custume de la Citee, ne deyvent my aler hors de la Citee par breve, ne en auter maner pur Item, les femmes apres le mort loure barouns, par custome de la Citee, averount loure francs bankz. Cest assavoire, un femme [avera] apres la mort son baroun, del tenement deinz la dite Citee dount son baroun morust seisi en fee, et en quel tenement le dit baroun et luy demorent en semble al temps del morant soun baroun, la sale, la principale chambre, et le celer entierment, et soun aysement en la cusyne, le stable, pryvee, et curtillage on comune, ou autres necessaries a luy appartaunts pur terme de sa vie :* et a quel heure qel soit marie el perdra le frank bank, et soun dowere dicelle, savant a luy dowere dez autres tenements comme le ley demaunde.

De Apprenti- Item, chescun frank homme de la Citee usant mystere poiet par cialte. usage de mesme la Citee prendre apprentice, de luy servyre et apprendre sa arte et sa mystre, et ceo par endentures que serrount faits parentre luy et son dit apprentice; les queux endenturez serrount examinez et enrollez de recorde, devaunt le Chamberleyn de la Guyhalle. $\dagger$ Et tiel apprentice poet lier luy mesmes, oue ses amys luy poent mytter a son mestre par loure endentours, sil soit de convenable age, solonc discrecioun del chamberlayn ou del Maire et

The endentures must be enrolled. Aldermans, si mester soit. Et nulle apprentice, par customme de la Citee, poet estre mys de meindre terme qe vij anz; et les endentures deyvent estre enrollez deinz vn an apres la fesaunce dicels, sur certein peyn ent lymyte. Et apres ceo qe tiel apprentice eit bien et loialment servy 'son terme il serra franc homme de la Citee, saunz autre redempcioun, la ou nulle autre poet avenire a la fraunchis

* In Lib. Alb. p. 393, there is a decision in a case which illustrates this Ordinance. See also $i b$. p. 68.

+ See an Ordinance of $28 \mathrm{Edw}$. I. as to the enrolment of apprentices, Lib. Custumarum (Rolls Series) p. 93. 
saunz redempcioun save ceux qe sount nees deinz la dite Citee, de quel pais qils soient del ligiaunce notre Seignur le Roy, par usage de la Citee; sount auxi francs par loure nestre, eiant regardant as privilegez de la fraunchise, come ceux quount estre apprentices, ou autrement avenuz a la fraunchise par redempcioun. Et lez femmes couverts qe usent certeyns craftis deinz la Citee par eux mesmes saunz loure barouns, poent prendre femmenis a loure apprentice, pur eux servier et apprendre loure craftes, et les queux apprenticez serrount liez par loure endenturez dapprenticialitee al baroun et sa femme, pur apprendre la mistere la femme comme devaunt est dit ; et tielx endenturez serrount enrolles sibien des femmes comme des hommez. Et fait assavoire qe chescun eiant tiel apprentice, poet Any one may vender et deviser son dit apprentice a qi qil voudra de mesme lart ${ }_{\text {his apprentice }}$ aux comme son chatel.*

Item, le ewe de Thamise si avaunt comme lez boundez de le fraun- Thamise. chis de la Citee purpartent est parcell de la Citee, et mesme la ewe et qiconque appent al dit ewe deinz la dite fraunchise tout temps ad estre en governaille de mesme le Citee, comme parcell de la Citee suisdite, sibien lun partie del ewe comme lautre. Et Viscountes de Lounderes qount estre pur le temps ount use de tout temps de faire arrestes et execuciouns al suyte dez parties en la dite ewe de Thamise. Cest assavoire, del Est partie le Pount de Loundres tanqe al Recolvere, et del West partie del dite Pount de Loundres tanque al Stanesbrige.

Item, lez dits Viscounts de Loundres deyvent par usage de la Cite avoire forfaitures des chateux de qiconques futifs et felouns et deodans deinz la dite Citee et la dite ewe de Thamise, en eide de loure ferme qils paient annuellement a notre Seignur le Roy.

Item, par custome de la Citee null atteynt est mayntenable, ne gist, deinz mesme la Citee.

* A Byelaw of a Worcester Gild, in the 17th century, points to the same custom of selling the interest in articles of apprenticeship. " English Gilds," p. 209. 
Nulle serra Item, par ancien custome de la Citee nulle homme demurant
treite hors del Citee par cause de villenage. deinz mesme la Citee soloit estre prie ne amesne hors du dit Citee, par coloure ne clayme de villenage, avaunt ceo qe la matier fuisse discusse par cours de ley.

Biens et mar- Item, si frank homme de la dite Citee, venant ou passant oue cez
chaundises detemur en nomme dé Withernam. marchaundisez aillours hors du mesme la Citee, soit constreynt de paier tolun ou autre customme, ou qe ses marchaundisez soient arrestuz ou cariez a tort et saunz resonable cause, et ceo soit sufficientment tesmoignez par gents creablez, adonqes si en apres les bienz ou marchaundisez des auters de mesme la ville ou le tort fuist fait soient trovez deinz la Citee de Loundrez, use est al suggestioun del partie de arrester tieulx bienz et marchaundisez par les ministres de la Citee, et lez deteiner en noun de Withername, tanqe gree soit fait al dit franc homme de lez dammagez queux il en avoit par cell cause; savaunt toutz foitz resonable respounce en celle partie, sibiene a lune partie comme a lauter.*

Nota le Tonne. Item, lez Citezeins de Loundrez dauncien temps ount ordeignez un meisoun appelle le Tonne sur Cornhille, a quel measoun constablez, Bedall, et autres officers et gentes de la Citee puis en ceo ount uses demesner, et illoeqes pur le temps enprisoner les trespassours alauntz nutandre encountre le peas, hommes et femmes espowses trovez en avowterie, et chapeleyns et autres religiousez trovez overtement oue comunes femmez, ou ouesqez femmes espouses nutandre en lieu suspeciousez; et puis lez amesner devaunt loure ordinaries.

Nully emple-
dra autre hors de la Citee. Conusaunce de pleez. Roy. Et use est qe nulle franc homme de mesme la Citee empledera auter frank homme de mesme la Citee, aillours qen mesme la Citee, la ou il poet avoir recoverer deinz la Citee avaunt-dit, sur peyn de perde la fraunchise. $†$

- Illustrations of the practice of this custom may be found in Lib. Alb. pp. 188, 619,670 .

+ See another form of this ordinance in Lib. Alb. p. 417; also ib. pp. 433, 478. 
Item, q'est Maire de Loundrez pur le temps avera un hanape dore Preevilegez al coronement de chescun Roy; et auxint sount autres privileges al Maire, de parteinantz au dit Mandres al parteinantz au dit Maire et a la Citee a tiel coronement du Roy, per coronement auncien custome de la Citee* le Roy.

Item, use este qe le chief Boteler nostre seignur le Roy serra chief The Coroner Coroner de la Citee de Loundres, et le quel Coroner ad use de faire and his duties per breve un substitute en son lieu, quel substitute est appelle Coroner, et devaunt qi lez enditements et appellez sount pris, et en qi nom lez Recordez sount faitz. Et toutz lez enditements et appellez dedeinz le dit Citee sount pris devaunt lez deux Vicountes et le Coronere, jointement. Et lez enquestis pris pur mort de homme sur la viewe del corps sount arraiez de quatre Gardes pluis procheins, et somonz par lez bedalx de mesmez lez gardez. Et toutz autrez enquestis de prendre devaunt lez Viscountes et Coroner en comune, deyvent estre arraies et somons par les Viscounts et loure Ministrez.

Item, avaunt cez heurez la ou ascun laroun esteant en la gaole de Appeal by Newgate avoit appele auter laroun esteant en ascun auter gaole, cel one another. laroun esteant en auter gaole soleit estre maunde per breve a la dite gaole de Newgate pur respondre al dit appele, et ester a sa deliveraunce la. Et en mesme le maner si laroun esteant en auter gaole

* In 11 Edw. III. a Petition was made in Parliament by Richard de Bettoyne, Mayor of London at the time of Edward's coronation, which shows the reason for this ancient right: " come au coronement nostre seignour le Roy q' ore est, il adonqe Meire de Londres fesoit l'office de Botiller, ove CCC e LX vadletz vestutz d'une sute, chescun portant en sa mayn un coupe blanche d'argent, come autres Meirs de Londres ount faitz as coronementz des progenitours nostre seigneur le Roy, dont memorie ne court ;" and he complains that "le fee q' appendoit a cel jorne, c'est assavoir un Coupe d'or ove la covercle, et un Ewer d'or enamaille," was delivered to him and afterwards charged upon him. Rolls of Parliament, vol. ii.p. 96. On the Thursday before the coronation of Richard II., John of Gaunt as Steward sat to hear claims and bills as to customary offices of right at the King's coronation, among which "Major Londini clamabat officium Pincernæ, et executus est, accipiens cupam auream." Lel. Coll. vol. i. pp. 254, 255. See also Taylor's Glory of Regality, pp. 140, 225.

CAMD. SOC. 
avoite appelle auter homme esteant en la dite gaole de Newgate, ou ascun auter deinz la dite Citee, mesme lappelloure esteant en auter gaole serroit amesne breve a la dite gaole de Newgate pur mayntener soun dit appelle. Et nulle laroun, esteant en la gaole de Newgate pris ou maynour, soilleit estre maunde aillours ouesqez la maynour pur estre a sa deliveraunce, mais soulement estre a sa deliveraunce devaunt le Maire de Loundres et autrez Justices assignez a la dite gaole de Newgate.

Town of Southwark.

Item, pur ceo qe la Ville de Southwerk et lez comunes estewis outre le ewe de Thamise sount si pres a la Citee de Loundrez, et larouns et autres meffesours sont souvent illeoques veinants et repairaunts, et souvent foiz, apres loure larcynes et felonies faitz dedeinz la dite Citee, tanqe a lez dites estewes et a la dite ville de Southwerk deinz fraunchis hors del poar de la Citee, pur demurrer illeoqes en muscettes, et attendre loure temps de revenir pur meffaire la; ount les ministrez de la Citee usee de tout temps de pursuer et serchier tieux larons et meffesours a lez dites estewes et en la dite ville de Southwerk, sibien deinz fraunchiz come de hors, et lez amesner a la gaole de Newgate pur attendre loure deliveraunce illoeqes devaunt lez Justices, sibien pur outre suspesioun come a le suyt de partie.

Prisoners arrested in the City must be tried there.

Item, lez prisoners qi sount condempnez ou arrestuz deinz la dite citee, et sount commys a prisone a suyte de partie, et puis sont mandes per breve al eschekker ou en autres places le Roy ouesques loure causez moismez lez prisoners, apres ceo qils soient deliverez en Court le Roy deyvent estre remandez a la dite Citee pur respondre a lez parties et attendre loure deliveraunce la.

Null serra Item, qount tenements deinz la dite Citee ne serrount mys soeffert de ab-
bater son tenement demesne. en deformacioun ne emblemishment de la Citee, sinon pur lez amender ou redresser. Et si ascun le face, ou comence a faire, il serra resst[r]eint par lez Maire et Aldermans et punyes pur le trespas, solonc le custome de la Citee. 
Item, si pariespentices ou autres tenements qiconqes deinz la dite Pent-houses in Citee, estendants vers lez hautes rewes, soient si veillez et si febles qe les gentes par my passants se dowtent pur perill de sodeyne rewynne, adonqes apres ceo qe tesmoigne soit as Maire et Aldermans par lez masounz et carpenters jurrez a le dite Citee, ou trove soit en Warde mote que le perill est ticl, adonqes mesmes lez Maire et Aldermans ferrount garnir la partie a qi lez tenements sount, a mesmez lez tenements de lez amender et redresser si hastyment come bonement purra. Et si apres tiel garnisement lez ditz tenements ne soient my amendez, ne commencez destre amender, dcinz $x l$ iours apres, adonqs serrount lez dits tenements amendez et redressez as costages de mesme la partiez. Et lez ditz demurrount en mayns de la dite Citee tanques lez costages ent fait soient pleynement levez, si le possessours dez ditz tenements nient autres bienz et chateux deinz la Citee. Et sil eit autres tenements ou bienz et chateux deinz la Citee, lez costages serrount levez de ces bienz et chateux, ou de cez autres tenements si meistir soit.*

Item, si ascun meisoun deinz la dite Citee soit ardants, issint qe la flamme del feu soit viewe hors de la ineasoun, celuy qest demurraunt en la dit.measoun paiera a lez $V$ iscountes $\mathrm{xls}$. en un bours ruge. $\dagger$

Item, lez Maire et Aldermans, Viscounts, et toutz autrez officers $\begin{gathered}\text { Election dez } \\ \text { Officers. }\end{gathered}$ et ministres du dit Citee, sount electifs par mesme la Citee. Cestassavoir, al temps qant le Maire serra esluz par lez comunez de la Election of the Citee, serrount par usage assemblez a la Guihalle, et mesmez lez poyor, his and comunes ferront eleccioun dez deux prodes hommes du dite Citee, dnties. des queux lun serra Maire; et lez nommes dez ditz deux prodeshommes serrount rapportes devaunt le Maire et Aldermans qi sount

* See a regulation as to "Appenticii" in $L i b . A l b$. p. 432; also $i b$. p. 323.

+ Laws similar to this were made in Bristol in 1575 and 1581. See MS. Brit. Mus. Egerton, 2044, fo. 5, and "Bristol Biographies: Whitson," by J. F. Nicholls, Bristol, 1870, p. 11. Probably there had been one earlier. See the last clanse of these ordinances, also the precautions against fire. in Worcester, temp. Edw. IV., in "English Gilds" (Early Fng. Text Society), pp. 382, 385, 386. 
pur le temps, deinz la Chambre du dit Guihalle, et adonqes lun dez deux serra esluz en Maire par lez ditz Maire et Aldermans illeoqes, par voie de skrutyn. Et le dit Maire, issint de novell eslu, lendemayn del fest des Seintes Symon et Jude serra presente devaunt lez Barouns de leschequer a Westminster, ou pur absens dez ditz Barouns al Constable del Towre, et en apres serra presente a notre seignur le Roy mesmes, solonc ceo qest contenuz en la Chartre du dit Citee. Et avera le dit Maire governaile de mesme la Citee de south notre Seignur le Roy pur la an ensuant. Et prendra la dit Maire 1. marcs par an pur pois dez Bleez, et 1. marcs en temps de peas dez marchaunts damyens, Corby, and Neel, solonc ancient composiciouns ent faitz.* Et chescun Maire tiendra sa courte generalle a la Guihalle le lundy prochein apres le fest-del Epiphanie. et illoeqes serrount ensemblez touts lez aldermans de la dite Citee. et toutz lez Constables, Scawageours, et Bedelles; et lez Wardemotes tenuz par lez Aldermans, et lez defautes trovez, serrount la liverez sus par lez ditz Aldermans en escript; et la serrount lez defautes trovez en gardez enquis et examinez, et lez Conustablez, Scawageours, et Bedelles serrount serements de novell, de bien et loialment faire loure office pur le temps qils serrount officers. Et le Maire qi pur le temps est, par custume de la Citee, pur mayntenaunce de la peas et tranquilitee deinz mesme la Citee, ad pouer darrester et imprisoner lez distourbours de la peas et autres meffesours, pur rebelliteez, malveisez paroles, et autrez defautes, solonqes sa discrecioun, saunz estre de ceo empechez ou empledez en apres. Item, nulle Maire serra eslu deinz la dite Citee avaunt ceo qil ad estee Viscount de mesme la Citee par un an devaunt. Item, lez Maires de Loundrez qount estee pur le temps ount uses davoir loure

* See the Agreement between the citizens of London and the merchants of Amiens, Corby, and Nesle, made in 1237, set out at length in Liber Custumarum, p. 64, and Liber Albus, pp. 418-428. A curious commentary on the words " in time of peace" is found in a petition in $13 \mathrm{Edw}$. III., on the Close Rolls, quoted in the French Chronicle of London, ed. G. J. Aungier (Camd. Soc. 1846), p. 69, note $\ddagger$, where it is stated that the fifty marks are lost to the Mayor, owing to the King's wars in France. 
espees hernoises de portes devaunt eux deinz la dite Citee et de hors, saunz deposer loure espees en nulle presence sinon en presence nostre Seignur le Roy; et tiel espee este apelle lespeye le Roy.*

Item, les Viscountez de Loundrez sount esluz, par usage de dite Cite, Election of the le joure de Seint Mathewe en la Guihall ; Cestassavoire, lun serra esluz $\begin{aligned} & \text { Sheriffs, their } \\ & \text { powers and }\end{aligned}$ par le Maire ou gardeyn qi serra pur le temps, et lautre par lez comunez. duties.

Et serrount lez dites Viscountez en apres jurrez deinz la dite Guihalle, et puis lendemayn de Seint Michell presentez en Eschequer ou al Conustable del Towre, solonc la fourme du chartre del dite Citee. Et averount lez ditz Viscounts franc eleccioun de touts loure officers et de loure fermers et baillifes, sibien deinz la dite Citee come en le County de Middlesex, et de lez gaolers dez gaoles deinz la dite Citee, a loure voluntie et a loure perill. Et mesmes lez Viscounts paient, et sount accomptablez annuelment a lescheker notre seignur le Roy, pur la ferme du la dite Citee et del Countie de Middlesex, solonc la fourme du dite chartre de la Citee. Et pur cause de quel ferme, lez ditz Viscounts deyvent aver lez aunciens prises et custumez des marchaundisez veinants deinz la Citee et passaunts dehors, et forfaitures, fynes, et amerciaments, et toutz autres commoditees dauncien temps partenants a loure dit office. Et nulle marchaundiz passera hors de la dite Citee par terre ne par ewe, par charecte, chivale, ne portage de homme, saunz bille enseale dez ditz viscounts; et ceux qe sount foreins deyvent paier pur lissue solonc launcien customme.

Item, lez Aldermans sount chescun an esluez en le feste de Seinte Election of AlGregorie et presentes a le Maire et serements. Et sount lez dits dermen, their Aldermans esluz par gentez du mesme le gardes; et lez queux duties. Aldermans deyvent tenir loure Wardemote, come la custome est, et survoyeir et redresser lez nusaunces et lez defautes en mesmes lez gardes, et reuler lez vitaillez, come aillours est declare plus a pleyn en lez Articlez de Wardemotes. Et lez Aldermans ount poer, par usages de la dite Citee, darrester lez contekours et autrez meffesours ct lez commytter en garde dez viscounts tanqes ils soient examinez

* See ordinances as to wearing arms, Lib. Alb. p. 387. 
et deliverez par le Maire et par mesmes lez Aldermans. Item, un Alderman apres ceo qil ad foitz este Alderman, ou un Viscount apres ceo qil ad este Viscount, ne serrount jammez empanellez ne mys en nulle enquest deinz mesme la Cite, pur usage dun dite Citee. Et de chescun feoffement et seisine live[r]e deinz la garde l'Alderman de le garde ou lez tenements sount avera son fee pur la seisine; cestassavoir iij s., et son bedell vj d.

Item, touts autres comunes officers de la Citee suisdite,-come de Recordour, Chamberleyn, Gardeyns del pount, comune Sergeant de Ley, comyn Sergeant de Maas, comyn Clerk, et sergeaunts de la Chambre,-sount esluz par Maire et Aldermans et par lez comunes;

Gates of the City.

London

Bridge.

Office de Chamberleyn. et lez bedalx sount esluz par lour Aldermans et par gens de la garde.

Et touts lez portes de la dite Citee deyvent estre en lez maynz et governaille du dite Citee, forspris la port du Busshopes-gate, quel porte partient as marchaunts de la Hans, solonc la forme dun composicioun ent fait, come pluis pleynment appiert par mesme la composicioun.* Et lez porters dez portes du dite citee sount esluz par mesme la Citee. Item, lez Gardeins del Pount de Loundres sount esluz par lez Maire et Aldermans, et par lez comunes du dite Citee; les queux gardeins ount le charge du dit Pount et la governaunce dez tenements dedeinz le dite Citee partenants a mesme le pount. Et chescun charecte alant ou venant sur mesme le pount ouesqez marchaundisez paiera al oeps du dit pount, iij d. Et chescun nief ou auter vessell oue marchaundisez, passant par ewe al dit pount vers le West ovesqez le mast esteant issint qil covient qe le pount soit treat suis, paiera pur la passage al oeps du dit pount xij d. Et tiell vessell passant illeoqes vers le Est paiera vjd. Et sount mesmes lez gardeins chescun an accomptablez devaunt deux Aldermans et quatre comuners, a ceo assignez.

Item, le Chamberleyn de le Guihall est esluz par Maire et Aldermans et par lez comunes. Et partient al office du dit Chamberleyn, qant il est issint eslu et serement, de garder toutz lez livers, rollez, recordes, et autres muniments et remembraunces qe deyvent de-

* This $A$ greement, made $10 \mathrm{Edw}$. I., is printed in Liber Albus, p. 485. 
murrer illeoqes de record, et le Tresore si ascun isoit. Et auxint gardera et sustiendra touts lez rentez et tenements partenaunts a la dite Chambre. Et gardera auxint lez tenements et lez deniers, bienz et chateux, queux sount devisez ou descenduz as Orphanyns, tanq' ils soient commys as autres persones ou autrement disposes par lez Maire et Aldermans.* Et fera enroller lez endenturez dez Appren-Endentures de ticialtees, et ferra sermentir lez apprenticez et ceux qe sount faits serrount en franks par redempcioun, et ferra lez fynz de tieulx redempcions; et rollez par le prendra fyns de ceux qe sount trovez rebellez a loure meistir et a lez gardeins dicell, et pur autrez certeinz defautes faitz encountre lez ordinauncez de la Citee. $\dagger$ Et lez devers ent provenants as divers officers pur loure salarie, come al Recordoure, Comune Sergeant de Ley, Comune Clerk, Comune Sergeant de Maas; et ferra autres costages partenaunts a soun office; et sur ceo rendra accompte un foitz en lan de qant qil ad receu, paie, et dispendu, et ceo devaunt dieux Aldermans et quatre comuners assignez par lez Maire et Aldermans.

Et auxint lez Citezeinz de Loundres avaunt ces heures ont Privileges in claimes et deyvent avoire plusours libertees et privileges en Eyere a Tyre at the la Toure de Loundres. Cest assavoir, ils devont avoire loure don. portour de hors lez portes del Towre, et le porter nostre Seignur ie Roy serra dedeinz, et loure Ussher al huys de la Seale de hors ou lez plees serrount tenuz deinz le Towre, durant tout leyre, pur amesner einz lez gentes de la Citee qount affaire en mesme leyere. Et le Vssher nostre Seignur le Roy se entermellera la durant tout leyre de choise qe partient al Office de Sergeaunt. Et qe lez Citeinz ferront nulle auter serement mais par la foy qils deyvent a notre Seignur le Roy, et qe lez Viscounts de Loundres averount la garde de touts loure prisoners en tout leyre; et qe nulle du dite Citee serra chace de respondre devaunt lez dits Justices en Eyre al Towre de Loundres de son franc tenement qest en la Citee àe Loundrez nen lez Suburbes de ycelle, sinon qe le plee soit ade primis attaine en Hustyng de Loundres, et puis soit remove devaunt lez ditz

* See before, p. 99.

† See before, p. 102. 
Justicez en Eyre, pur ceo qe celluy qest enplede, avouche forein, a garaunt qi riens nad dienz la fraunchis du dite Citee forspris lez disseysines fait en la dite Citee puis la somons del Eyre. Et qe lez pleez comencez en lez Courtes de Loundres, et la pendaunts deyvent estre terminez la, saunz ceo qils este mys ou remoevez devaunt ascun Justice nostre Seignur le Roy, sinon qe ascun chose soit allege par lun dez parties dount la Courte ne purra mye conustre ou terminer. Et plusourz autres points et privilegez, comme en diverses Eyres al dite Toure de Loundres tenuz pluis pleinement poet appareire. Et auxint plusours autrez libertees, privileges, et customes sount partenaunts a la Citee de Loundrez, dount nulle homme poet avoir remembraunce de toutz pur lez mettere en escript; lez queux libertees, aunciens privilegis, et custumes, ne deyvent my estre mys en escript einz soulement recordez par bouche quant ils veignent en fait, par custome de mesme la Citee. Et fait assavoire, q'al darrein Eyre tenuz al Toure de Loundres lez Citezeinz de Loundres duissent aver este arcez par lez Justices de claimer loure libertees et loure customez. Sur qoy mesmes lez Citezeinz suerount loure peticioun au Roy en cestes paroles:-

Petition to the King as to "Treschiere Seignur, par la ou votre dite Citee est foundee sur claim of priviEyre of the Tower. fraunchisez et franc custome aunciens, et nient sur comune ley, comme autrez Citeez de votre Roialme, et a ceo le graunde Chartre voet qe la Citee de Loundrez eit touts cez liberteez, fraunchisez, et franc custumez desblemes, et mesmes lez fraunchisez et custumes soient a eux par vous progenitourz grauntez et pur vous mesmes confermes, et eux de tout temps ceo en arere soient uses en Eyere et pur aillours devaunt Justicez, quelle hure qils venussent, en fait ou en demande loure fraunchisez et customes recorder; et ici ore en cest eyre voz Justicez leyent mys a respoundre par quel graunt ils claymont lez ditez fraunchisez et custumez, et par estatut fait puis le darrein Eyre, et amettre loure fraunchisez et custumez en certein, quel lez chosez sen de homme ne poet remembrere. Please a vostre Seignur commaunder a vostrez ditz Justices qils soient menes et tretez en chalange de loure dites fraunchisez et customes solonc ceo 
qe aunciement devaunt lestatut en autrez Eyeres soleient este tretez et mesnez, et qe par nulle estatut contrary a loure dites fraunchisez et custumez soient liez ne oustez de loure fraunchises et custumes aunciens." Et sur ceo fuist maunde breve a lez Justices de sursere.

Item, si ascun meason soit trove deinz la dite Citee ou lez Roofs of straw, suberbez coverez de streyn, de rede, ou de Shyngell, celluy a qi le $\begin{aligned} & \text { reed, or } \\ & \text { shingle. }\end{aligned}$ measoun est paiera as Viscounts qi sount pur le temps xls., et serra constreint doustere tiel coverture.*

\section{[The annexation of Bristol Castle to the City.] †}

[1] To the Queenes excellent Matie, the humble Petition of the Fo. $322 b$. Maior, Burgesses, $\ddagger$ and Comminaltie of the Citty of Bristol. Humbly shewinge unto your Matie that the Cittie of Bristoll hath

* This law must have been made later than that of 1212, as "shingle" was then allowed. See "Liber Custumarum," p. 87, and Introd. p. xxxii. See also before, p. 107.

$\dagger$ The documents given above, written in a contemporary hand, occupy fos. $322 b$ to $324 b$, being the last in the volume upon which anything is written, except the Index before mentioned (p. x). The originals are in the State Paper Office, Domestic Series, vol. 121, Nus. 57 to 57-vi., and vol. 141, No. 77, with which these have been collated. The Petition to the Queen [1] has there been bound up with the year 1629; the paper too bears an old endorsement, " April 1629," but the Bristol Copy, though not dated, puts it into its right place, namely, with the Petition to the King [2] (of a date before 25 November 1628) which is expressly said to be " hereunto annexed." They relate particulars of the preliminaries to the obtaining of the charter of 13 April, 5 Charles I. (1629), by which the Castle and its precincts were annexed to the City and put under its jurisdiction. They are here given exactly as they stand, but, as the writer did not take much heed to the order in which he copied the papers, the figures between brackets have been added to indicate their succession. The charter itself is printed in Seyer's Charters of Bristol, pp. 205-213. The Castle was finally demolished in 1656, the only portion of it now in existence being what is supposed to be a part of the entrance to the banqueting hall, which is built into a tenement in Tower Street. For some particulars as to its early history see Barrett, 197-199; Seyer's Mem. Brist., i. 328-330; Corry and Evans' Hist. of Brist. (ed. 1816) i. 270, note ; also see William Worcester, Dallaway's Antiquities of Bristow, 1834, pp. 148, 155-7.

‡ The word "Burgesses". is not in the original in the State Paper Office.

CAMD. SOC. 
aunciently bene reputed and called the Chamber of the Queenes of England, as London is called the Kinges Chamber, ${ }^{*}$ and it hath pleased the Queenes of England, your most noble predecessors, especially the late Queene of famous memory his noble $\mathrm{Ma}^{\text {ties }}$ most renowned Mother, soe to esteme thereof as to receiue and take the same unto her especiall fauour and protection whiles she liued. And bycause the same Citty is parcell of your $\mathrm{Ma}^{\text {ties }}$ joincture wee most humbly pray your $\mathrm{Ma}^{\text {tie }}$ to receiue it into your Highnes favour, and that your Matie would be graciously pleased to recommend this petition hereunto annexed vnto the Kinges most excellent $\mathrm{Ma}^{\text {tie }}$, that his $\mathrm{Ma}^{\text {tie }}$ by your princely mediation would referre the consideration thereof to the Lord Cheife Justice of his Bench, the Lord Cheife Barron of his Exchequer, Mr. Attorney Generall, or any two of them, who may certifie and inform his $\mathrm{Ma}^{\text {tie }}$ of the fitnes and conueniency of the suite thereby desired to be graunted.

And your Petitioners accordinge to their bounden dutie shall with all humblenes acknowledge your $\mathrm{Ma}^{\text {tie }}$ their gracious benefactor, and ever pray for your $\mathrm{Ma}^{\text {tie }}$ health and happines.

[2] To the King's moste excellent Matie. The humble petition of the Maior, Burgesses and Cominaltie of the Cittie of Bristoll.

Moste humblie prayinge for the Reasons within mencioned, That your $\mathrm{Ma}^{\text {ties }}$ Castle of Bristoll and liberties thereof maye be vnited and made parcell of the Countie of Bristoll and be vnder the government of the Maior and Justices of the Cittie, the same nowe lyinge in the Countie of Gloucester, and suffered to be a receptacle for all lewde people where noe justice is administred.

They beseech your $\mathrm{Ma}^{\text {tie }}$ to grante their request, referringe the consideracion thereof to the Lord Chiefe Justice of your $\mathrm{Ma}^{\text {ties }}$

* See before, p. 54 note*, p. 65 . 
Bench, the Lord Chiefe Barron of the Exchequer, and Mr. Attorney Generall, or any two of them. And uppon theire Certificates of the conveniencie thereof order maye be given to your $\mathrm{Ma}^{\text {ties }}$ learned Councell for drawinge a Booke accordinglie, for your royall signature.

[4] At the Court at Whitehall, $25^{\circ}$ Nouembris, 1628.

$\mathrm{His} \mathrm{Ma}^{\text {tie }}$ is graciously pleased to referre the consideracion of this petition to the Lord Treasurer of England, and the Chauncellor of the Exchequer, to be certified their opinions touchinge the conveniency and inconveniency of the petitioners request.

Ralph Freeman.

[5b] May it please your good $\mathrm{Lo}^{\mathrm{ps}}$.

We have considered of this petition and of the reasons thereto annexed, and wee conceaue the desire of the Citty of Bristoll in the petition expressed to be verye convenient for the government of the place, which is nowe a lawlesse place and full of all disorders.

And we doe not conceaue that any inconvenience cann come thereby, nor any cann take any just exceptions therevnto but thos only who desire to liue dissolutely and without controll of gouernment.

Some of us knowe the place well and haue observed the disorders thereof as it now stands part of the County of Gloucester. But if it be annexed to the County of the Citty of Bristoll ther is great hope that by their care thes great abuses will be reformed.

All which we humbly submitt to your $\mathrm{Lo}^{\mathrm{ps}}$ great wisdomes and judgments.

NI: HYDE.

Jo: WALTER.

Jo: Denham. Ro: Heath.

20 Februar. 1628. 
[5] May it please your $\mathrm{Ma}^{\text {tie. }}$.

According to your gracious referrence we haue considered of this Petition, and for our more clearer satisfaction herein wee haue desired the opinions of some of the Judges and Mr. Attorney, touching the conveniency or inconveniency of that graunt. And by their Certificate wee finde (which is annexed vnto the Petition) that it will rather bee beneficiall then hurtfull that the Castle bee graunted vnto the Towne and County of Bristoll. Soe that seeing the reasons therein alledged wee doe concurre in the same opinion with them, and see noe inconvenience for the passinge of the graunt as is desired in the Peticion.

All which notwithstanding we leave vnto your $\mathrm{Ma}^{\text {ties }}$ greater wisdome.

R. Weston. E. Newburgh.

March the 18th, 1628.

[6]

Whitehall, 25th March, 1629.

His $\mathrm{Ma}^{\text {tie }}$ is gratiously pleased that the Castle of Bristol and liberties thereof bee vnited and made parcel of the Countie of Bristol, and bee under the government of the Maior and Justice of the Cittie, as in the petition annexed is desired. And Mr. Atturney is to prepare a graunt for his $\mathrm{Ma}^{\text {ties }}$ signature, expressing the same to bee done at the Queenes request and for her honour.

JoHN CoKe.

[3] The Reasons in the Petition aforesaide mentioned.

Humbly shewinge,

That Kinge Edward the Thirde made by Charter your Ma ${ }^{\text {ties }}$ nowe Cittie of Bristoll a Countie, which lay before within the Counties of Somersett and Gloucester. 
That your Maties Castell of Bristoll is lyinge within the Countie of Glouc', yet standeth within the circuit and bounds of the said Cittie.

That 200 poore persons at the leaste are nowe dwellinge within the precincts of the said Castle, and moste of them live by begginge, besides a greate number of outlawed, excomunicated, and other lewde offendours that fly the face of justice (by whome God is dishonnored and the Comonwealth oppressed) doe there shelter themselves as in a place priuiledged and exempte of all government and authoritie, to the greate anoyance of your loyall subiects.

That if any murthers, manslaughters, or other felonious crymes bee there comitted, the offenders are to be sente to Gloucester (30 myles distant) to be tryed and punished as the lawe requireth.

That vppon the late occasion of impressinge souldiers and marryners for your $\mathrm{Ma}^{\text {ties }}$ service a greate multitude of able men fledd thither, as to a place of freedome (where malefactors live in a lawles manner), by meanes whereof Justice was afronted, the service delayed, and the gouernment of your said Cittie vilified and abused.

That your $\mathrm{Ma}^{\text {tie }}$ woulde be gratiouslie pleased, the premisses considered, to vnite and annex the said Castle and precinctes thereof with thappurtenances to the Countie of your said Cittie, and be made parte and parcell of the said Countie of Bristoll, and that all offences whatsoever there comitted maye from henceforth be reputed and taken to be comitted and don within the Countie of the Cittie of Bristoll, and may be heard and determyned by the Maior and Justices of the said Cittie from time to time accordinge to your $\mathrm{Ma}^{\text {ties }}$ lawes, and as in like cases is nowe vsed within the said Cittie.

And your Peters accordinge to their bounden duties shall euer praye for your $\mathrm{Ma}^{\text {ties }}$ long and happie raigne ouer vs. 
$[5 a]$

December 2, 1628.

Wee desire my Lo. Chiefe Justice of England, my Lo. Chiefe Baron, Sir Jhon Denham, and Mr. Atturney, to consider of this petition and the reasons herevnto annexed, and to certify us their opinions concerning the conueniency or inconueniency of passing this grant.

R. WESTON.

E. Newburgh. 


\section{IN D E X.}

Admiralty, order of, as to anchorage at Bristol, 57

Advent sermons, 85

Alban's, St., battle of, 41

Aldermen of London, 109

Aldworth, Thomas, 61, 62

Alhallowen, money said to be stolen from church of, 40 ; deeds belonging to the same church, iii, vi note, xxvi note; custom of the Mayor on day of, 79

All Saints (sce Alhallowen)

Amiens, Corby, and Nesle, agreement with merchants of, 108

Anne Bulleyn, present to, by Town of Bristol, 54

Anne, Queen of James 1., visits Bristol, 65-67

"Anthony" and other ships lost, 46

Apprentices,enrollment of their endentures, $102,103,111$; women may take, 103

Armada, Spanish, 62

Arthur, King, xi, xiv note

Arthur, son of Hen. VII., birth of, 47

Avalon, isle of, 13, 14

Audley, Lord, slain at Bloureheath, 42

Augustine's Abbey, foundacion of, 20, 22 ; grant of land by, to the town, 28 ; surrender of, 55 ; variance between Abbot of, and Town of Bristol, 56 note

Back, the, repaired, 40

Bailiffs of Bristol, 33-46:-

Albone, Thomas, 34 bis

Alburton, John, 39

Alburton, Richard, 40

Algode, Simon, 37

Arves, Richard, 38

Asshe, Thomas, 40

Babcary, Henry, 34 (3)

Bagod, John, 41

Bagod, Clement, 38

Baggod, Nicholas, 38
Bailiffs of Bristol, continued-

Bailly, Richard, 39

Balle, Henry, 43

Balle, Thomas, 39

Banbury, John, 36

Barboure, Galfrid, 37

Baret, William, 37

Baroghe, Peter, 36

Barstable, John, 36

Barstable, Robert, 37

Bate, John, 35

Batkok, John, 46

Beaufloure, John, 33

Beauner, Roger, 34

Benet, John, 40

Benley, William, 37

Beufloure, Galfrid, 35

Beupeny, Thomas, 35

Birde, William, 43

Blanket, Edmund, 34

Blanket, Thomas, 34 bis

Blont, Thomas, 37

Blount, John, 35 bis

Bokerell, Henry; 37

Bolton, Robert, 41

Bonde, Richard, 46

Brandone, Richard, 35

Brokworth, Richard, 37

Brokworth, Robert, 37

Browne, Edmund, 38

Bulle, Robert, 41

Burtone, John, 37, 38

Calne, Richard de, 34

Candavir, Robert, 36

Canynges, William, 35 bis, 36, 39

Capull, Philipp, 46

Cary, Jaurence de, 33

Castelcare, John, 34, 35

Castelle, John, 37 bis

Cheddre, Robert, 35

Chestre, Henry, 41

Chestre, Jolın, 46 
Bailiffs of Bristol, continued-

Cleve, John, 37

Clynche, William, 39

Cobynton, John, 34 bis, 35

Codir, William, 39

Cogan, John, 41

Cokkys, James, 37

Colpek, Richard, 33

Colston, Thomas, $\mathbf{3 6}$

Colvelde, Robert, 37

Combe, William, 35, 36

Costone, Walter, 43

Coton, John, 38

Coventre, Thomas de, 35

Curteys, John, 34

Dagon, William, 35

Damme, William, 39

Dene, Richard de, 35

Derby, Walter, 35 (4)

Devenyssh, Nicholas, 38

Dillyng, William, 40

Draper, John, 38

Draper, William, 36, 37

Droyes, John, 37

Druez, John, 46

Dudbroke, Robert, 37 bis

Dudbroke, David, 37

Dunstar, William, 39

Elysaunder, Richard, 38

Englisshe, John, 39

Erle, Thomas, 38

Erlyngham, William, 36

Estirfielde, John, 45

Estmonde, John, 40

Eston, Henry de, 33

Excestre, Nicholas, 37

Eyre, John, 38

Eytone, John, 43

Fisshe, Thomas, 38

Flexalle, Thomas, 45

Forde, John, 39

Foster, John, 43

Foster, Richard, 39

Framptone, Henry de, 34

Fraunces, Euerard le, 33 bis, 34

Fraunces, John, 33 bis

Freme, Nicholas, 39

Frensshe, Reynald le, 35

Freo, Nicholas le, 34

Frome, William, 36

Gaywodde, John, 42

George, John, 41

Gildeney, Henry, 38

Gloucestre, Thomas, 37
Bailiffs of Bristol, continuedGodard, John, 44

Godemer, Robert, 34

Gosselyne, John, 39

Greffithes, Galfrid, 43

Gregory, John, 45

Grymstede, Walter, 44

Gurney, John, 45

Gyen, Robert, 33, 34

Haddone, Richard, 39

Halwey, Thomas, 38

Hanny, William, 34

Hanteford, Richard, 37

Hanyngfield, William, 33

Hardewyk, John, 37

Hauering, John, 36

Haukes, John, 41

Hatter, Richard, 39

Hay, Thomas at, 36 bis

Hayle, William, 35

Haynes, William, 34 bis

Heethe, John, 38

Hendy, Thomas, 37

Hextone, Thomas, 45

Hille, Nicholas, 39

Hoke, John, 38

Holburst, Robert le, 33

Honte, John le, 33

Hoopere, John, 40

Hore, Thomas, 39

Hotton, William, 41

Howelle, William, 39

Inhyng, Adam, 37

Inhyng, John, 35

Inhyng, Richard, 35

Inhyng, Thomas, 35

Jakys, Robert, 40

Jaye, John, 41

Joce, Gilbert, 37

Kempson, Thomas, 40

Kene, John, 35

Knappe, Thomas, 36

Langley, John, 38

Langbridge, Hugh de, 33

Lemman, John, 37

Levedone, Roger, 38

Lexam, John de, 34

Leycestre, John, 37

Long, Nicholas, 40

Lutelbury, Robert de, 33

Markes, Thomas, 39

Marshall, Richard, 39

Mede, Philipp, 39

Mede, Thomas, 39 
Bailiffs of Bristol, continued-

Milton, Walter, 38 bis

Milton, John, 38

Mors, Lewis, 42

Nancotone, John, 44

Nele, John, 34

Newtone, John, 37

Noreys, Thomas, 39

Norton, Thomas, 37

Panys, Richard, 37

Parle, Walter, 37

Parle, Andrew, 38

Papenham, John, 39

Pavy, William, 39

Paynes, Richard de, 33

Peers, John, 38

Pelevile, Walter de, 34

Penke, John, 45

Pluste, Roger, 34

Powere, Walter, 38

Powke, John, 44

Pownesham, William, 39

Prentise, Walter, 33

Prentise, Robert, 34

Preston, John, 35

Pristone, John, 36, 37

Prowte, Hugh le, 33

Puckerell, Gilbert, 33 (3)

Randalf, Robert, 33

Raynes, William, 40

Rayny, James de, 34

Rayny, Joceus le, 34 bis

Rogers, Thomas, 39

Rokys, William, 43

Rolffe, William, 40

Roper, Richard, 39

Rowley, Thomas, 44

Rowley, William, 45

Ruddok, David, 37

Rumsey, John de, 33

Russelle, Robert, 37

Sampson, Thomas, 36 (3)

Saymour, Walter, 36

Selwodde, John, 37

Sely, John, 37

Seynte, John, 42

Sharpe, John, 37, 38, 40

Shermone, Richard, 45

Shipwarde, John, 38, 39, 44

Skrevyn, John, 44

Skyrmot, William, 39

Sloo, John, 35

Snell, William, 36

Snethe, John, 38

CAMD. SOC.
Bailiffs of Bristol, continued-

Snygge, John, 45

Sodbury, John, 37

Solers, William, 37

Somervell, John, 36

Somerwell, William, 35 bis

Soor, John, 35

Spelle, Elyas, 35 bis

Spencer, William, 40

Spicer, Thomas le, 33 bis

Spycer, Stephen le, 33, 34 (3)

Spycer, John le, 34, 39

Spysour, Thomas le, 33

Spyne, John, 37

Stanes, John, 36 (3)

Stanley, John, 39

Stephins, John, 36, 45

Stephins, William, 37

Stodley, Walter, 36 bis

Stoke, John, 35 (3)

Stone, Nicholas, 39

Strange, Robert, 43

Sturmy, Robert, 39

Sutton, John, 37

Swayne, John, 45

Talbot, John, 38

Talbot, William, 39

Testyne, Peter, 34

Tilley, Thomas, 34

Tilley, James, 34 bis

Toket, William, 45

Torpen or Turpyn, Thomas, 34 (4)

Touker, Roger, 36

Trenolde, Richard, 38

Tryt, John, 36

Troyte, John, 38

Turtle, Clement, 33 bis

Tyddeley, Walter, 36

Vaghan, Henry, 44

Vyell, Henry, 35 bis

Vyell, John, 35 bis

Vynypeny, Henry, 33

Walishot, John, 33

Wall, John at, 34

Warmystre, William, 36

Welle, Robert at, 35

Wenelake, Walter, 34

Westcotte, Edmund, 44

Westirley, William, 38

Wethiforde, Hugh, 38

Wethrforde, John, 39

White, Richard le, 33

White Iremonger, Richard le, 33

Wiliston, Henry, 35 (3) 
Bailiffs of Bristol, continued -

William, Mark, 37

Wilshire, Clement, 46

Wodderove, William, 35

Wodyngtone, William, 42

Wryngtone, Robert de, 34

Wroxall, Galfrid de, 33

Wykam, John, 40

Wykam, William, 44

Wynemone, Ralph, 33

Yonge, John, 36

Yonge, Thomas, 37

Bakers and bread, 82

Banbury, battle of, 44

Banwell, 23

Barnet, battle of, 45

Bath, first bishop of, 23

Beaumont, Lord, 42

Bedford, Duke of, buried at Keynsham, 48

Berkeley-hernes, manor of, 21

Berkeley, Roger of, 20; marriage between daughter of, and son of Robert Harding, 22

Bermondsey, 14

Berton, Honour of (including Bristol), 18-20

Bishopric of Bristol created, 55 note

Bokerell, Walter, of London, 27

Botoner (see Worcester)

Bosworth field, 46

Boy-bishop, xix, 80 .

Brewers and ale, 83

Brick building, first in Bristol, 68

Bridge upon the Were, 47

Bridge of Bristol, 57, 67

Bridgewater river, new cut made in, 57

Bristol, said to be built by Brynne, 10: plan of, $x, 10$; Castle, 19, 113-118; list of mayors, \&c., 27-46; various style of municipal officers, xvii ; the Queen's Chamber, 54, 65, 114; made into a Bishopric and City, 55 note; records

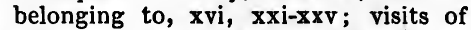
Princes to, xviii note, 26, 39, 40, 43, 45, $48,58,65,68$; money given to Princes by, $45,48,54,58,65$; paving of streets, 47,57 ; Cornish rebellion withstood by, 49 (see Charters)

Brunswick, Duke of, visits Bristol, 64

Bruton, canons regular, 15, 23

Buckingham, Humfrey, Duke of, 42

Buckingham, Henry, Duke of, 46

Buildings, none may pull down, 106; assize of, 93, 94; pent-houses, 107

Bye-laws (see Ordinances)
Canynges, William, 36, 44 (see Bailiffs, Mayors, and Sheriffs); his chantries, 79 Carpenter, Bp. of Worcester, 44

Carr, John, bequest for an orphanage, 56 note, 62

Carthusian order, 14, 15

Chamberlain of London, 110

Chantries in Bristol, 77 note, 79 ; oaths of priests of, before the Mayor, 76

Charters to Bristol, of John, 18, 24, 25, 91 ; Henry III. 4, 25 note; Edward IV. 43; Edward III. 51, 69, 90, 91

Christmas, peace to be kept during, 85

Cistercian order founded, 14

Coal, old pits of, near Bristol, 84 note; standard measure for, 84

Coinage, debasement of, 68

Comptoir or Tolsel, repair and decoration of, 52,53 note; new one built, 57 ; proceedings there, 75, 79, 84

Constables, 78

Corn provided for the people by the Mayor and others, 49, 52, 61, 62, 63

Cornish rebellion against Henry VII., 48

Coroner, power to choose, 25

Coronation, King's, privilege of Mayor of London at, 105

Coroner of London, 105

Crafts, masters of, to take oath before the Mayor, 77, 78 note

Cranbourn Abbey, 18

Crosses of Bristol, x, xi, 48, 51

D'Arcy, Henry, xx, 6, 93

Debt, pleas of, 96

Drawings in this book, description of, $x$ xiii

Dower of women in London, 102

Dutch, fight with, off the South coast, 67

Eclipse in 1433, 39

Edward IV. came to Bristol, xviii note, 43, 45; his death, 46

Edward VI. birth and christening of, 54

Egremont, Lord, 42

Eleanor, niece of King John, died at Bristol, xvi note, 17

Elizabeth, Queen, yisits Bristol, 58; conspiracies against, in the West, 61

Error, process of, in I,ondon, 100

Expenses of Bailiffs of Bristol, 81

False news, liars and bearers of, punished, 96 
Fire, precautions against, 107, 113

Fitz Elwyn's Building Assize, 93

- Floods, mischief done by, 46, 64

Ford Abbey, 15

Forfeitures fall to the Sheriffs, 103

Fountains Abbey, 15

France, exchange of ambassadors with, to establish peace, 58 ; arrival of noblemen in London, 60

Frank burgage in Bristol and London, 2, 97

"Free bench" of women in London, 102

Frobisher, John, arrival of two of his ships, 60

Frome river, 29 note

Fulford, Baldwin, 43

Gaunts, a religious house, surrendered, 55 ; what succeeded it, 56 note, 62

Gates, four, of Bristol, 3, 10

Genoese merchants, sued by Mayor of Bristol, 41

George, St. feast of, $81^{-}$

Gibb Taylor, 28, 59

Gildhall of Bristol, 69, 70, 71, 72, 79

Glastonbury, 7, 13; abbey burnt, 15; combined with Bath, 23

Gloucester, Robert Earl of, 19, 23

Gloucester, William, 19, 20, 23

Gloucester, decree of Star Chamber against Town of, 52

"Golden Lyon" of Bristol lost, 60

Gunpowder, xxiii, 59.

Halwey's chantry, 77 note

- Harding, Robert son of, 20, 22, 29 note

Harding, Maurice, 22, 29 note

Haymon, Robert, 18

Henry III. crowned, 26; at Bristol, 4, 26

Henry V., death of, 38

Henry VI. came to Bristol, 39, 40

Henry VII., marriage of, 47 ; came to Bristol, 48

Henry VIII. does not come into Bristol because of the plague, 53

Herbert, brother of Lord, slain at Bristol, 44

Heysaunt, John, beheaded, 43

High cross, $x, 48,64,74$

Hustings of London, enrolments in, 98

Irish burgesses, suit by, against Mayor of Bristol, 41 ; ordinances against, 41 note

Irish money, men imprisoned for bringing into Bristol, 47
Isabell, daughter of William Earl of Gloucester, 19, 24

Jocelyn, Bishop, 23

Kalendars, Gild of, $\mathrm{v}$ note, 73

Kalendars, manuscript, in Bristol, xiii

Katherine, St. custom on festival of, $x i x, 80$

Kayage in Bristol, 50, 52

Keynsham, Abbey of, 20, 23

Keynsham, Richard of, 28

Kingswood Abbey, 15, 23

Kitchin, Robert, gifts of, 63

Langable, xxiii, 2 note

Law-day in Bristol, 56 note, 79

Lennox, Duke of, visits Bristol, 64

Liars and deceivers punished, 96

Liveries of town officials, details of, 81

London, intention to throw down the walls, 27; new weather-cock on St. Paul's, 38 ; a precedent for Bristol, 6 , 93 ; extracts from customs of, 93-113; held in frank burgage, 97; the Mayor's Court and its functions, 95, 108; citizens need only obey the King's direct orders, 100; liberties and privileges are declared by mouth, not written, 102; election of the Mayor, his powers and duties, 107-109; election of Sheriffs, their powers and duties, 109 ; election, \&c. of Aldermen, 109; other officers chosen, 110; gates of the City, 110; the Chamberlain, his office and duties, 110; privileges in Eyre at the Tower, 111113

London Bridge, 110

Ludlow, Court at, Bristol not within its jurisdiction, 51

Magdalen, house of, in Bristol founded, 22 Market in St. Thomas Street, 58; a new one, 63

Martin le Grand, Justices at, 101

Mary, Queen of Scots, 62

Matthew of Westminster used by Ricart, 17,25

Mayor of London, 95, 105, 107-109

Mayors in Bristol from an early date, xvi, 69 ; election of, xii, 70-74; oath of, 72 ; record of xvi

Mayors of Bristol :-

Adryan, John, 30

Adryan, Henry, 30 bis 
Mayors of Bristol, continuedAdryan, Walter, 32

Aldworth, Thomas, 61

Axbridge, Elias de, 30

Axbridge, John de, 34

Axe, William de, 33

Aylard, Richard, 28 bis

Babcare or Babcary, Thomas, 35 bis

Bagod, Clement, 39 bis

Bagod, John, 46

Banbury, John, 37

Bardeney, Symon de, 31

Barker, John, 64

Barnes, John, 62

Barstaple, John, 37 (3)

Bathe, John, 35 bis

Bays, Clement, 53

Beauflure, William, 31

Beaupeny, Thomas, 36 bis

Bele, Robert le, 29

Berdewyke, John de, 27

Berewyke, Henry de, 27

Berkham, Adam de, 30 bis

Berkham, Roger de, 30

Birde, William, 45, 62

Blount, Thomas, 37, 38

Brandon, Bichard, 35

Browne, Jordan, 28

Browne, John, 58

Bruselaunce, John, 27

Burton, Symon de, 32 (5)

Burton, John, 38, 39, 40 bis

Bury, Roger de, 30

Canynges, William, 36 (6), 39, 40, $41,42,44$

Canynges, John, 37 bis

Cheddre, Robert, 35 bis

Chester, William, 54

Clerk, William, 29

Clerk, Symon, 31

Cleve, John, 37, 38

Cobyntone, John, 35

Codir, William, 40, 41, 43

Cogan, John, 45

Coke, Roger, 53

Cokere, Thomas, 31

Cokkys, James, 38

Cole, Richard, 61

Colstone, Thomas, 60

Derby, Walter, 35 bis, 36 (3)

Draper, Richard le, 31

Drewes, John, 48

Droyes, John, 37 bis, 38

Dudbroke, Robert, 37
Mayors of Bristol, continued-

Esterfeld, John, 47, 48

Fayreforde, Hugh de, 27

Fissher, Roger, 31

Fissher, John, 37, 39

Forstall, Richard, 28

Forster, Richard, 39 bis, 40

Frampton, Walter, 35 bis, 36

Fraunces, John, 34

Fraunces, Everard le, 34 (3)

Fraunces, Gerard le, 31

Fraunces, Walter le, 28, 32

Freme, Nicholas, 39

Frensshe, Reynold, 35 bis

Frome, William, 37 bis

Gloucestre, William de, 30

Graftone, Roger de, 31

Grave, Thomas de la, 32

Gyen, Robert, 34 (3)

Halleway, Thomas, 39

Hameslesden, Thomas de, 31

Hatter, Richard, 41

Haukes, John, 45, 48

Heyhome, Nicholas, 27

Hille, Nicholas, 39

Holburst, Robert, 27

Hore, William, 33

Horncastell, Nicholas, 31

Horston, Richard, 28

Hulle, John at, 27.

Hurte, Ralph, 63

Hutton, John, 51

Jakys, Robert, 44

James, Thomas, 64

Jay, William, 57

Jeffrys, Thomas, 55

Kedgwin, Christofer, 64

Kelke, Thomas, 58

Kempson, Thomas, 45

Keynesham, Peter de, 31

Keynesham, John de, 33

Kitchin, Abel, 64

Knappe, Thomas, 36, 37 (4)

Kylmaynan, Robert de, 30 bis

Langebrige, Hugh, 34 bis

Langley, Philip, 61

Levedon, Roger, 38

Leycestre, John, 38, 39

Long, Henry le, 27

Long, Elias, 30

Lydeyarde, John, 31

Lyme, John de, 30

Mangottesfielde, Richard, 2, 31 bis, 32 bis 
Majors of Bristol, continued-

Mauncelle, Robert, 3]

Mede, Philip, 41, 43, 44

Mersshefielde, John de, 27

Miltone, John, 39

Mombray, Walter, 27

Monjoy, Ralph, 29

Newtone, John, 38 bis

Nortone, Thomas, 38

Ormestone, Stephen, 30

Pacy, Thomas, 52

Page, Adam le, 27

Paldene, Ralph, 31

Panys, Reginald de, 33

Parfey, William, 63

Passoure, Robert, 33

Penes, Reginald de, 30

Penke, John, 47

Pepwall, William, 57

Pepwall, Michael, 62

Powlet, Philip, 28

Prewett, John, 59

Pyke, Walter, 61

Randalf, William, 32, 33 (3)

Regent, William, 48

Repe, John, 56

Roberts, John, 60

Rogers, Thomas, 42

Romeney, Clement de, 30

Romeney, Peter de, 31 bis

Rous, Thomas le, 30 bis

Rowborowe, James de, 27

Rowland, Thomas, 61

Rumney, John de, 33

Rumsey, John de, 33

Russell, Robert, 38 bis

Selby, Thomas, 30

Seler, John du, 33

Sely, John, 37

Shipman, John, 49

Shipman, William, 53

Sharp, John, 38, 39 bis

Shipwarde, John, 39, 41, 43, 44, 46

Somerwell, William, 36

Somerwell, John, 37

Snowe, John, 32, 33

Snygge, George, 59

Spakstone, William, 29

Spelly, Elias, 35, 36 bis, 37

Spencer, William, 44, 45, 46

Spryngham, Elyas, 28

Spryng, John, 55

Spycer, Stephen le, 34 (3)

Spycer, John le, 34, 35
Mayors of Bristol, continued-

Spycer, Richard le, 35 (3)

Spyne, John, 38

Stanes, Roger de, 27

Stanley, John, 39, 40

Stephens, John, 37, 47

Stone, John, 58

Stokes, Roger de, 30

Stokes, John, 35, 36

Stoke, John, 35

Strange, Robert, 45, 46, 47

Sturmy, Robert, 40

Tavyrnere, Roger le, 31

Tavyrnere, John le, 33 (3)

Tilley, Thomas de, 32 bis

Tilley, Richard de, 33 (4)

Toker, William, 48

Tortle, Roger, $.32,33$ bis

Trenolde, Richard, 39

Tucker, William, 58

Turtle, Roger, 32, 33, 34 (7)

Vaghan, Henry, 46, 47

Vndiryate, Martin, 27

Vyell, John, 36

Wade, John, 60

Ware, John, 51

Warre, James le, 28

Warre, John le, 31

Wellis, Richard de, 31

Wescote, Edmund, 47

Weston, Thomas de, 28

Wethrforde, Hugh, 39

White, Galfrid le, 30

White, Thomas, 51

Whitson, John, 63

Whyte, Henry, 56

Wight, Reynold de, 30

Wikeham or Wykham, William, 46,47

Wilkyns, John, 50

William, Mark, 38

Wilteshire, Clement, 48

Wissy, John, 31

Wosley, William, 49

Wryngtone, Robert de, 34 bis

Wycombe, John, 35

Wykam, John, 43

Wyntone, Walter de, 27

Yate, William, 63

Yonge, Thomas, 37

Measures, reformation of, in Bristol, 58

Michael's, St., Bristol, 54, 57

Middleton monastery, 14

Minor Friars, 15, 16

Monasteries in Bristol, surrender of, 55, 56 
Monmouth, Geoffry, used by Ricart, 6, 8-10

Muchelney, 14

Mumming, 85

Murage, 52

Newgate, 105

Nicholas, St. custom on the eve of, 80

Northampton fight, 42

Nuisances, Assize of, 96

Oaths, the taking of, by certain officers, 75

Oaths of Mayor, 72.74, 88 note; Townclerk, 75 note, 88; Recorder, 87; Sheriff, 88; Bailiff, 90

Obits, 80

Ordinances for internal government, 73, 74,96

Orphans, the care of, 99, 100, 111

Orphans' causes, Act of Parliament for, 63

Parliament, of 1216 held in Bristol, 4, 26; members of, paid by Sheriffs of Bristol, 49,50

Pembroke, Earl of, received in Bristol, 61

Pent-houses, 107

Pole, William, Duke of Suffolk, murder of, 40

Poor, special relief to, 63

Plague in Bristol, 53, 59, 63, 64 (see Sweating)

Pleas in London, 104

"Prepositi" " of Bristol, 27-30 :Atteslupe, Ralph, 27

Ayleward, Thomas, 28

Bawdewyne, Ralph, 30

Bellomonte, William de, 29

Bellomonte, Robert de, 30

Belyetere, John le, 28

Berkham, Walter de, 30

Berwyk, John, 30

Berwyk, William de, 30

Bradewas, John de, 27

Bryan, Richard, 27

Brydde, Ralph le, 30

Bury, Richard de, 27, 28

Callande, John de, 28

Camene, Henry de, 27

Cantok, Roger, 28

Caperon, Thomas, 30

Chadborne, William, 30

Chalner, Thomas le, 28

Cheynere, Henry le, 29

Chiltone, William de, 29

Clerk, William, 28
"Prepositi" of Bristol, continued-

Cok, Philip le, 27

Coker, Nicholas, 27

Cokke, Stephen le, 30

Colpek, William, 27

Cornehill, John, 30

Cute, Paul, 29

Daxe, William, 27

Eldesham, Thomas, 30

Ergleys, John, 28

Exhulle, John, 30

Farneham, Henry, 30

Frebody, William, 30

Golde, William, 28

Golde, Roger, 30

Goldesmyth, Peter le, 27

Hanyngfield, Thomas de, 30

Hayle, William le, 27

Hazarde, Reginald, 27

Hazildene, William, 30

Hertishorne, John, 30

Horneby, Robert, 30

Keredief, John de, 28

Knolle, John at, 30

Kylmanan, Robert, 29

Leigh, William de, 29

Leymstre, Richard de, 28

Marlebrege, Gilbert de, 30

Martyn, Richard, 27

Martyn, Robert, 27

Methelam, John, 27

Monmouth, Robert de, 27

Mychell, Hugh, 30

Northfolke, John, 28

Norwodde, Thomas de, 30

Oldeham, John, 27

Oldeham, Ralph, 30

Osmonde, Richard, 28

Palmer, Richard le, 27

Parmenter, Robert, 29

Pedyrtone, Thomas de, 28

Pepyr, Roger, 30

Plommer, Gilbert le, 28

Portbury, Nicholas de, 27

Puxton, Henry de, 30

Pykerage, Robert, 30

Rede, Walter le, 27

Romney, John de, 27

Rope, Alexander, 27

Russhton, Richard de, 30

Sancta Barba, John de, 30

Sevare, William, 30

Shyrley, Robert, 30

Snake, Roger, 29 
"Prepositi " of Bristol, continued-

Snake, William, 30

Snowe, John, 27

Spycer, Thomas le, 27

Stanekyn, Stephen, 27

Talmage, Walter, 30

Tonarde, William, 28

Trenworth, Robert, 30

Trenwyth, Thomas, 30

Tropyn, Walter, 30

Tyarde, William, 27

Tylloy, Richard de, 30

Upwell, Hugh, 27

Vbbeley, Walter de, 27

Vpdiche, Thomas, 28

Vssher, Galfrid, 30

Vynepeny, Henry, 27

Walle, John at, 28

Walleys, Henry le, 28

Westone, Robert de, 27

Westone, John de, 30

Wight, David le, 28

Wodde, Robert at, 30

Wynfyelde, Thomas, 30

Prisoners, appeal by, 105; trial of, 106

Proclamations, various, in the town, 78, 85,86

Quarrer, Abbey of, 15

Queen's Chamber, Bristol called, 54, 65, 114

Queens, presents to, by Bristol, 54, 58, 65

Ray liveries, xii, 81

Reading Abbey, 15

Recorders of Bristol, xxiv, 58, 63, 65, 87; their oath, 87

Redcliff, early charters and incorporation of, $x \times \mathrm{v}, 28,29$ note ; church, 32, 36, 44

Retail, strangers may not sell by, to one another in London, 100

Ricart, Robert, account of, ii-vi; his will doubtful, iii

Ricart, Philip, iv

Rutland, Edmund, Earl of, 42

Sack wine, 59, 60

St. Alban's, battle of, 41

Salisbury, Richard, Earl of, 42

Saltmarsh, 46

Savaric, bishop, 15, 23

Saxonsfield, battle of, 43

Scavage in Bristol, action in the Common Pleas as to, 50

Secks, a Spanish wine, 59, 60
"Senescalles " of Bristol, 30-33 (see Stewards)

Sewers near Bridgwater, 57

Sergeants to give their bonds, 76

Sherborne, translation of See from, to Salisbury, 22

Sheriffs of Bristol, charges borne by, 50 note; payments by, to Members of Par. liament, 49; commission and oath, 75

Sheriffs of Bristol, 36.46; picture of, xi :Alburtone, Richard, 43

Arveys, Richard, 39

Bagod, Clement, 39

Bagod, John, 41

Bagod, Nicholas, 38,

Balle, Thomas, 40

Banbury, John, 37

Barstable, John, 36

Baroghe, Peter, 36

Baxster, Robert, 37

Beupeny, Thomas, 36

Beneley, William, 38

Birde, William, 44

Blont, Thomas, 37

Boltone, John, 39

Burtone, John, 38

Candavir, John, 36

Candavir, Robert, 36

Canynges, John, 36

Canynges, William, 39

Chestre, Henry, 45

Cleve, John, 37

Codir, William, 39

Cogan, John, 43

Cokkys, James, 37

Coombe, William, 36

Colvelde, Robert, 38

Damme, William, 41

Devenysshe, Nicholas, 38

Droyes, John, 37

Dudbroke, Robert, 37

Dudbroke, David, 38

Erle, Thomas, 38

Excestre, Nicholas, 37

Fissher, John, 37

Fissher, Thomas, 39

Foorde, John, 39

Forster, Richard, 39

Forster, John, 45

Freme, Nicholas, 39

Froome, William, 36

Gaywodde, John, 44

George, John, 44

Gloucestre, Thomas, 37 
Sheriffs of Bristol, continued-

Gyldeney, Henry, 38

Halwey, Thomas, 38

Hatter, Richard, 40

Hauering, John, 37

Hawkys, John, 43

Hay, Thomas at, 37

Hill, Nicholas, 39

Hooper, John, 44

Hore, Thomas, 40

Howell, William, '40

Jakys, Robert, 42

Jaye, John, 45

Kempson, Thomas, 42

Knappe, Thomas, 36

Leycestre, John, 38

Lyvedon, Roger, 38

Mede, Philipp, 41

Mede, Thomas, 40

Newton, John, 38

Nortone, Thomas, 37

Pavy, William, 40

Powere, Walter, 39

Pryston, John, 37

Rogers, Thomas, 41

Roper, Richard, 39

Rowley, Thomas, 45

Ruddok, David, 38

Russell, Robert, 38

Sampsone, Thomas, 36

Saymoure, Walter, 37

Sely, John, 37

Sharpe, John, $\mathbf{3 7}, 38$

Shipwarde, John, 39 bis

Skryvene, John, 46

Somerwell, William, 36 bis

Somervell, John, 36

Spencer, William, 43

Spycer, John, 39

Spyne, John, 37

Stanley, John, 39

Stephins, John, 37

Strange, Robert, 44

Studley, Walter, 36

Sturmy, Robert, 40

Towker, Roger, 37

Trenolde, Richard, 38

Troyte, John, 39

Vaghan, Henry, 46

Vyell, Henry, 36

Vyell, John, 36 bis

Warmynstre, William, 37

Wedington, William, 45

Westcotte, Edmund, 45
Sheriffs of Bristol, continued-

Wethrforde, Hugh, $39^{\circ}$

William, Mark, 37

Wodroof, William, 36

Wykam, John, 41

Wykam, William, 46

Yonge, Thomas, 37

Sheriffs of London, 109

Ships of Bristol taken by Genoese, 41 ; lost near the town, 46, 47, 59, 60

Shrewsbury, Earl of, $\mathbf{4 2}$

Smithfield, Statute of, 96

Southwark, order of Canons of St. Mary, 15 ; town of, 106

Speke family, 57

Stalenge Cross, 51

Stanley, Sir William, beheaded, 48

Staple, Mayor's Commission of, $\mathbf{7 6}$

Stewards of Bristol, 30-33 :-

Adryan, Symon, 31 bis

Austyne, Richard, 31

Axe, Ralph de, 31

Benyngtone, John, 31

Berwyk, William, 31

Berwyk, Thomas de, 33

Beufloure, Roger, 32

Bostok, Robert, 32

Boys, Guillemyne de, 31

Bryan, John, 31

Burtone, Symon de, 32

Burtone, Nicholas de, 33

Canto, Roger de, 31

Cheddre, John de, 31, 32, 33

Collepyt, Richard, 32

Colston, Thomas, 31

Draper, Roger, 31

$\mathrm{Eu}$, Reginald le, 31

Fraunces, John, 32 bis

Glastunbury, William de, 32

Glenne, Walter, 32

Goddeshalf, Galfrid a, 32 bis

Goldyng, Robert, 31

Harssalle, John, 32

Haseldene, Thomas, 31

Hawdene, William, 31

Hobbusshe, Robert, 32

Hodde, John, 31

Horehurst, Robert, 32

Horncastelle, Henry, 31

Kerdyef, John de, 31

Kyngeswod, Robert de, 31

Lancastle, Robert, 31

Langbrige, Hugh de, 32 bis

Legat, John, 31 
Stewards of Bristol, continued-

Longe, John le, 31, 33

Lung, John le, 32

Martre, Peter, 31

Maryna, William de, 31

Maryner, William le, 32

Mychelle, Hugh, 31

Oke, Nicholas at, 31

Oke, Richard atte, 31

Olyef, William de, 33

Oterey, Robert de, 32 (3), 33

Peperton, John, 30

Pokerell, Gilbert, 33

Portisheued, John de, 31

Prestlay, Thomas, 31

Randolf, William de, 32

Ricard, Reginald, 30

Romney, John, 33

Rowborowe, Nicholas, 32 bis

Roborowe, William de, 32

Roystone, Thomas, 31

Rycrofte, Symon, 32

Salekene, John, 31

Skryvene, William le, 31

Snelle, Galfrid, 31

Snoward, Robert, 31

Snowe, John, 32

Tavirnere, John le, 32

Tombrelle, Richard, 31

Tony, John, 31

Trewelove, Robert, 3 ]

Tropyn, Walter, 33

Tyke, John, 32

Vpdyche, Thomas, 32

Vpdyche, William, 32

Wedmore, Symon de, 31

Wedmore, William de, 31

Welishot, Adam, 32, 33

Westone, Thomas de, 31

Wissy, John, 31

Wychewelle, William, 31

Wylmersshe, Robert de, 31

Streets in Bristol paved, 48, 57

Sturmy, Robert, his ships taken by the

Genoese, 41, 42 note

Surrey, Earl of, in Bristol, 56

Swart, Martin, 47

Sweating sickness, 47

Sword for Sundays, 61 ; of Mayor of London, 108, 109
Swyneshede, John of, 28

Tavistock, 14

Templars, order of, 15

Tewkesbury, agreement with, as to kayage and murage, $5 \mathrm{l}, 52$

Tewkesbury Abbey, 18

Thames, river, 103

Thorne, Robert, bequest of, for young clothmakers, 53

Thornbury, Henry VIII. stayed at, 53

Tintern Abbey, 15

Tolsey or Counter (see Comptoir)

Tonne on Cornhill, 104

Towton, battle of, 43

Town Clerk's oath, 75, 88

Trench cut from the Frome into the Avon, 28

Tudor, Owen, death of, 42

Verses, leonine, on English kings, 7, 11

Villeinage in London, 104

Units of gold, purse of, presented to Anne of Denmark, 65

Wales, Marches of, Bristol not included in, 51 ; Lord President of, visits Bristol, 64

" Wast, Brief de," 98

Watch, Midsummer, xix note

Waterford, two men of, taken to London, 47

Wells Cathedral, 23

Westbury, 23

West country raised by Warwick against Edw. IV. 44 ; conspiracies against Elizabeth there, 61

Westminster, Matthew of, xvi, 17

Whitson, John, 63

Wills in London, custom by which made, 97-99 ; enrolled of record in full hustings, 98

William Conqueror, 16, 17

Withernam, custom of, 104

Wishart, George, lecture and consequent persecution of, in Bristol, 55

Women, dower of, 102

Wood, regulation of the sale of, 83

Worcester, William, vi, 7 note

York, Richard Duke of, 42 
WESTMINSTER:

PRINTED BY J. B. NICHOLS AND SONS, 25, PARLIAMENT STREET. 


\section{REPORT OF THE COUNCIL}

\section{OF \\ THE CAMDEN SOCIETY, \\ READ AT THE GENERAL MEETING \\ ON THE 2ND MAY 1872.}

The Council of the Camden Society elected on the 2nd of May 1871 have to regret the loss of the following members of the Society who have died during the present year :-

William Henry Black, Esq., F.S.A.

Sir Thomas Phillipps, Bart., F.S.A.

The Rev. C. W. Stocker, D.D.

J. Godfrey Teed, Esq., Q.C.

The following Books have been issued during the past year:-

I. The Fortescue Papers, consisting chiefly of Letters relating to State affairs, collected by John Packer, Secretary to George Villiers, Duke of Buckingham. Edited from the Original MSS. in the possession of the Hon. G. M. Fortescue, by Samuel Rawson Gardiner, Director.

This volume consists chiefly of a miscellaneous collection of letters which were apparently thrown aside by the Duke of Buckingham after he had read them. One paper, a letter of James I., relating to Raleigh's trial, is of peculiar importance, and the remainder have been selected by the Editor from a much larger number, on account either of the interest which attaches itself to the writer, or of some historical information contained in the letter itself.

II. Letters and Papers of John Shillingford, Mayor of Exeter Á.D. 1447-1450. Edited by Stuart A. Moore, F.S.A. 
These very early specimens of private correspondence have an especial value, as throwing light upon the practical working of our institutions for the administration of the law in the reign of Henry VI.

III. The Old Cheque Book, or Book of Remembrance, of the Chapel Royal, from 1561 to 1744 . Edited from the Original MS. preserved among the muniments of the Chapel Royal, St. James's Palace. By Edward F.'Rimbault, LL.D., \&c., \&c.

This book is full of notices of English musicians connected with the Chapel, and gives curious and minute particulars of Royal Ceremonies, Funerals, Coronations, Churchings, Baptisms, Marriages, \&c.

IV. A true relation of the Life and Death of the Right Reverend Father in God William Bedell, Lord Bishop of Kilmore, in Ireland. Edited from a MS. in the Bodleian Library, Oxford, by Thomas Wharton Jones, F.R.S.

The Council regret that, from causes beyond their control, the third volume of the Trevelyan Papers is not yet in the hands of the members. They believe, however, that it will be ready for issue almost immediately. On the other hand, the Council have been able to substitute one of the volumes intended for the forthcoming year before the date at which it was due.

It is proposed that the issue for the year 1872-3 be, in addition to the Life of Bedell, already sent out,-

The Mayor of Bristol's Calendar. By Robert Ricart, Town Clerk, Bristol, temp. Edward TV., with a continuation subsequently added at various dates. Edited by Miss Lucy Toulmin Smith. [Almost ready.]

Letters addressed from London to Sir Joseph Williamson, while Plenipotentiary at the Congress of Cologne, in the year 1673. Edited by W. D. Christie, C.B.

In explanation of the accounts, it is to be observed that the amount now paid towards a General Index amounts to $£ 350$, and that there remains about $£ 160$ in hand applicable to further payments on that account out of the stock sold out of the Funds last year. This $£ 160$ appears as part of the Treasurer's balance in the accounts of the present year.

With respect to the Index itself, Mr. Gough reports that 101 out of the 105 volumes are either indexed or in progress, and that he hopes to complete his work in about another year. 
The following Books have, in the course of the past year, been added to the list of suggested Publications:-

1. Two Chronicles of the Reign of Henry VI., from MSS. in the Lambeth Library. To be Edited by James Gairdner, Esq.

2. Dispatches of French Ambassadors in England in the time of Henry VIII.

3. A Letter containing an account of the pensions paid by the Spanish Government to the Ministers of James I. To be Edited by Don Pascual Gayangos.

4. Letters and Papers illustrating the charges brought against the Duke of Buckingham at his impeachment in 1626 . To be Edited by SAmuel Rawson Gardiner Esq, Director.

5. Notes of Debates in the House of Commons in 1625. To be Edited from the MS. in the Library of Sir Rainald Knightley, Bart. To be edited by Samuel Rawson Gardiner, Esq., Director

The Council have now the pleasing task of announcing that their appeal, made at the commencement of the new series, has been responded to by the addition of thirty names to the list of members. They trust that this may be accepted as a pledge of a still greater increase, and they would urge upon the members the necessity of assisting the progress of the Society by securing as many additional subscribers as possible. Without dwelling upon the past services of the Society to historical literature, they believe that they may fairly point to the names of the five Books added to the list of suggested Publications, as an evidence of their wish to supply, within the limit of their means, those wants which are felt by the students of every period of English history.

By order of the Council,

SAMUEL RAWSON. GARDINER, Director. WILLIAM J. THOMS, Hon. Secretary. 


\section{REPORT OF THE AUDITORS.}

$W_{E}$, the Auditors appointed to audit the Accounts of the Camden Society, report to the Society, that the Treasurer has exhibited to us an Account of the Receipts and Expenditure from the 1st of April 1871 to the 31st of March 1872, and that we have examined the said accounts, with the vouchers relating thereto, and find the same to be correct and satisfactory.

And we further report that the following is an Abstract of the Receipts and Expenditure during the period we have mentioned.

Receipts. $\quad$ s. $d$.

To Balance of last year's account. . 5591011

Received on account of Members whose Subscriptions were in arrear at last Audit

The like on account of Subscriptions due on the 1 st of May, $1871 \ldots . .261$

The like on account of Subscriptions due on the lst of May, 1872....

To two Compositions in lieu of Annual Subscription ................

One year's dividend on $£ 4663$ i 3 per Cent. Consols, standing in the names of the Trustees of the Society, deducting Income Tax..

To Sale of the Publications of past years.................................

To Sale of Promptorium Parvulorum (3 vols. in 1) ......................

Cheque not presented.

is ${ }^{261}$
20000 2000 $\begin{array}{lll}4 & 5 & 6\end{array}$ Paid for printing 500 copies, Fortescue Papers, No. 1 Paid for binding 400 copies of ditto ....................... Paid for printing 500 copies of Shillingford Letters, No. 2

Paid for binding 400 copies of ditto...

Paid for Transcript ditto

26100 Paid for printing ' 500 copies of Cheque Book of Chapel Royal, No. 3..............................................

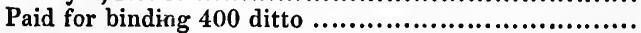
Paid for Woodcut..................................... No 4 printing 500 copies, Life of Bishop Bedell, Paid for binding 400 ditto

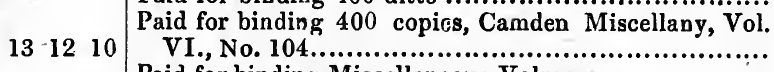

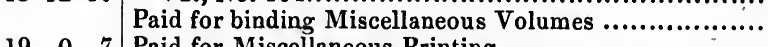

19 . 7 Paid for Miscellaneous Printing.

Paid for delivery and transmission of Books, with $9 \quad 1 \quad 3$ paper for wrappers, warehousing expenses (in-
$£$ s. $d$. $42 \quad 146$ $\begin{array}{lll}15 & 4 & 0\end{array}$ $\begin{array}{lll}54 & 14 & 0\end{array}$ $\begin{array}{lll}14 & 8 & 0\end{array}$ $\begin{array}{lll}20 & 2 & 6\end{array}$

8280 $\begin{array}{lll}15 & 4 & 0\end{array}$ $\begin{array}{rrr}3 & 0 & 0\end{array}$ $\begin{array}{lll}75 & 7 & 6\end{array}$ $\begin{array}{lll}15 & 4 & 0\end{array}$ $\begin{array}{lll}14 & 5 & 0\end{array}$ 2180 $\begin{array}{lll}9 & 8 & 0\end{array}$ $\begin{array}{lll}33 & 6 & 6\end{array}$ $\begin{array}{lll}70 & 9 & 0\end{array}$ $\begin{array}{lll}40 & 0 & 0\end{array}$ $\begin{array}{lll}4 & 5 & 6\end{array}$ $\begin{array}{lll}6 & 13 & 0\end{array}$ $418 \quad 10$ $\begin{array}{lll}0 & 3 & 0\end{array}$ $\begin{array}{lll}390 & 9 & 9\end{array}$

And we, the Auditors, further state, that the Treasurer has reported to us, that over and above the present balance of $£ 3909 s$. $9 d$. there are outstanding various subscriptions of Foreign Members, and of Members resident at a distance from London, which the Treasurer sees no reason to doubt will shortly be received. 
Remoral of Wrecker (AD 1579) h.60

The modu of Lating the vath

Dae cllastar of each craft the husented ithe ellayor 


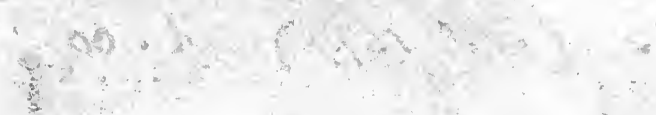

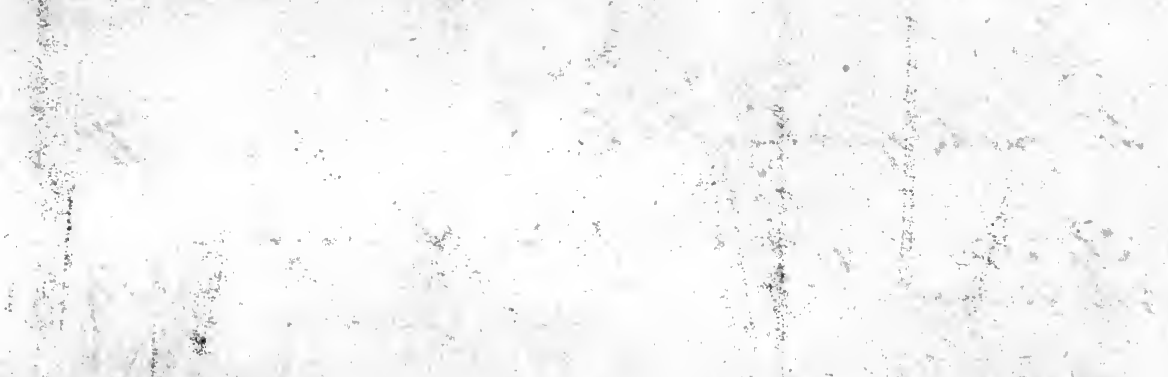

$\left(\frac{1}{2} t^{2}\right.$

$\therefore$ क

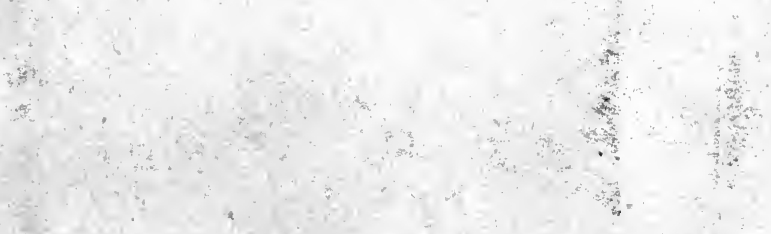

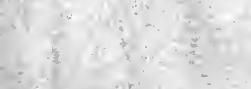

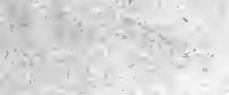

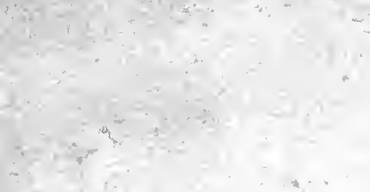


DA

20

$\mathrm{C} 17$

n.s.

no.5

CIRCULATF AS MOMORRANH

PLEASE DO NOT REMOVE

CARDS OR SLIPS FROM THIS POCKET

UNIVERSITY OF TORONTO LIBRARY 
